\title{
Risk Control in Recycled Water Schemes
}

\author{
ZHUO CHEN, HUU HAO NGO and WEN SHAN GUO \\ School of Civil and Environmental Engineering, University of Technology Sydney, \\ Broadway, NSW 2007, Australia
}

Recycled water is becoming one of the indispensable and reliable water resources at present. When it is introduced as an alternative source, risks on human health and the environment become major constraints driving the application and extension of recycled water. This paper examines the sources and associated risks of recycled water and introduces the practical risk control technologies on various end uses. This paper also reviews some existing risk assessment models by comparing their strengths and weaknesses towards the good approach of integrated modelling. Some critical suggestions on risk management and communication are made based on the given information.

KEYWORDS: Recycled water; end use; risk control; risk assessment; quantitative risk assessment models

Address correspondence to Huu Hao Ngo, Centre for Technologies in Water and Wastewater, School of Civil and Environmental Engineering, University of Technology Sydney, Broadway, NSW 2007, PO Box 123, Broadway, NSW 2007, Australia; Tel: +61 2 9514 2745; Fax: + 6129514 2633; Email: h.ngo@uts.edu.au 


\section{INTRODUCTION}

As a result of population increase, surface water quality deterioration, groundwater depletion, severe drought and climate change, water scarcity has already heavily emerged as one of the most pressing problems, which limits socio-economic growth in the 21st century (Anderson, 2003; Asano et al., 2007). In this case, many countries have been continuously seeking alternative water resources including the capture and use of rainwater, stormwater, recycled water as well as desalinated water. Compared with others, recycled water contributes to a considerable reduction of wastewater discharge to aquatic environment, a relatively constant water supply during the year, acceptable infrastructure and energy consumption costs, and great human benefits (Anderson et al., 2001; Huertas et al., 2008). With increasing interest in the use of recycled water for multiple purposes (e.g., irrigation, industrial, residential, recreational, indirect potable reuse (IPR) and direct potable reuse (DPR) applications), it has been essential to guarantee the safety, acceptability and reliability of recycled water for human health and the environment (Rose, 2007). Risk control is apparently an important approach and one of the determinative factors to the success of water reuse schemes. According to different water reuse schemes and particular end uses, risk control methods vary widely, but the principle is substantially the hazard removal and exposure minimization.

Historically, the risk control on water reuse was far from optimism due to limited treatment conditions, poor socio-economic situations and low public recognitions (International Water Management Institute (IWMI), 2010). At that time, as unplanned and uncontrolled use of sewage and other effluents were commonly observed at downstream cities along the river, including London, Sydney and Pretoria, catastrophic epidemics of waterborne diseases were broadly reported (Van Leeuwen, 1996). For example, during the 1850 s, using wastewater either directly or via food from Broad Street in London resulted in the outbreak of cholera and more than 500 deaths within 10 days. In 1993, the largest 
waterborne disease outbreak originated from human and cattle faeces has happened in Milwaukee, the U.S., which caused 400,000 people sick and 100 deaths together with \$96 million in medical costs and productivity losses. The disease was attributed to the failure in removing cryptosporidium cysts or oocysts from contaminated raw water so that they survived even after water filtration and chlorination treatment processes (Logsdon, 2006). In 1998, Sydney has also experienced a water crisis which caused by the occurrence of Cryptosporidium- and Giardia-bearing low-quality wastewater entering Warragamba dam after heavy rainfall (Stein, 2000). Worse still, Anon (1996) reported that waterborne pathogens had infected around 250 million people each year leading to 10 to 20 billion deaths by 1996 . Fortunately, since the 1960 s, regulatory pressure and water shortage have provided basic motivation for risk management in water reuse engineering. Besides, water reuse guidelines specifying acceptable risk values have been gradually established and will continue to be revised towards more stringent ways (Hespanhol and Prost, 1994).

Over the last 10-15 years, with the rapid development and widespread acceptance of membrane technologies in wastewater treatment coupled with real-time monitoring programs, the risk associated with the occurrence of waterborne hazards has been drastically reduced. These efforts have further broadened the recycled water applications and driven the exploration of new end uses such as clothes washing, fire fighting and IPR, especially in developed countries (Pearce, 2008). However, in less developed countries, the absence of financial and technical resources make above-mentioned advanced techniques unrealistic so that other risk control solutions such as exposure control, health protection and better management of wastewater should be intensified (Asano, 2001; Qadir et al., 2010). Therefore, the primary objective of this study aim to investigate the occurrence of potential hazards in recycled water and find effective risk control methods towards different water reuse schemes under specific natural, social and economic conditions so as to ensure public 
health and environmental safety. Furthermore, this study introduces risk assessment approaches which have been evolving continuously, from simplified, qualitative and imprecise ones to more realistic, quantitative and complicated analyses. The relevant risk assessment models are also discussed, where the integrated ways are the main tendency which not only consider variability and uncertainty in quantitative risk assessment but also combine other site specific models (e.g., water quality model, hydraulic model and disease transmission model) to represent local reality. Based on these conclusions, recommendations of sound risk management and communication solutions are put forward.

\section{SOURCES AND ASSOCIATED RISKS OF RECYCLED WATER}

Wastewater effluents coming from previous uses, such as greywater, municipal wastewater or industrial effluents are dominant sources of recycled water. Each source of recycled water has its own characteristics and constituents, in which the concentration of particular chemical substances or the number of microbial pathogens varies significantly (Toze, 2006a). Thus, recycled water from different wastewater origins poses different risk levels to human health and the environment, and may have distinct strengths and weaknesses for certain reuse purposes. For example, a wastewater from a chemical industrial plant would have a lower risk of microbial pathogens but a higher risk of chemical hazards than domestic greywater (Toze, 1997). Consequently, it is important to understand all kinds of recycled water sources and to what extent are the risks.

\section{Greywater}

Greywater generally refers to urban wastewater that includes water from household kitchen sinks, bathrooms, showers, hand basins and laundry machines but excludes any input from toilets (Eriksson et al., 2002; ATSE, 2004; Li et al., 2009). As these different input streams 
have intrinsic waste contents and the water quality always varies substantially, their risks to human health and the environment are diverse. Table 1 lists the key risks of greywater associated with each stream. As can be seen, greywater from kitchen sinks contains the highest concentration of pathogens and organic contents, followed by laundry and bathroom sinks (Christova-Boal et al., 1996; Li et al., 2009). For mixed greywater, the potential risks can be categorized into all three aspects. 
Table 1. The characteristics of greywater in typical households by different categories ${ }^{\mathrm{a}}$

\begin{tabular}{|c|c|c|c|c|c|}
\hline Stream & $\begin{array}{l}\% \text { of water } \\
\text { consumption }\end{array}$ & Contents & Key risks & Typical water quality & \\
\hline $\begin{array}{l}\text { Bathroom, } \\
\text { showers and } \\
\text { hand basins }\end{array}$ & $26-55$ & $\begin{array}{l}\text { Hair, soaps, } \\
\text { shampoos, lint, } \\
\text { toothpaste, nutrients, } \\
\text { body fats, oils and } \\
\text { cleaning products } \\
\text { (occasional lint, fabric } \\
\text { fibres, skin, urine and } \\
\text { faeces) }\end{array}$ & $\begin{array}{l}\text { - Faecal contamination risk } \\
\text { to public health } \\
\text { - Build up of chemicals on } \\
\text { soils, vegetation and } \\
\text { groundwater }\end{array}$ & $\begin{array}{l}\mathrm{pH} \\
\text { TSS (mg/L) } \\
\text { Turbidity (NTU) } \\
\text { COD \& BOD }(\mathrm{mg} / \mathrm{L}) \\
\text { TN \& TP (mg/L) } \\
\text { Total coliforms \& faecal } \\
\text { coliforms }(\mathrm{CFU} / 100 \mathrm{~mL})\end{array}$ & $\begin{array}{l}6.4-8.1 \\
7-505 \\
44-375 \\
100-633 \& 50-300 \\
3.6-19.4 \& 0.11->48.8 \\
10-2.4 \times 10^{7} \& \\
0-3.4 \times 10^{5}\end{array}$ \\
\hline $\begin{array}{l}\text { Laundry } \\
\text { troughs and } \\
\text { washing } \\
\text { machines }\end{array}$ & $15-34$ & $\begin{array}{l}\text { Clothes washing } \\
\text { detergents and } \\
\text { bleaches; } \\
\text { lint, oils, greases, } \\
\text { chemicals, soaps, } \\
\text { nutrients; } \\
\text { occasional paints and } \\
\text { solvents }\end{array}$ & $\begin{array}{l}\text { - Faecal contamination risk } \\
\text { to public health } \\
\text { - Build up of detergents in } \\
\text { soils, vegetation and } \\
\text { groundwater } \\
\text { - Bleaches and disinfectants } \\
\text { can potentially kill } \\
\text { organisms in the soils }\end{array}$ & $\begin{array}{l}\mathrm{pH} \\
\text { TSS (mg/L) } \\
\text { Turbidity (NTU) } \\
\text { COD \& BOD }(\mathrm{mg} / \mathrm{L}) \\
\text { TN \& TP }(\mathrm{mg} / \mathrm{L}) \\
\text { Total coliforms \& faecal } \\
\text { coliforms }(\mathrm{CFU} / 100 \mathrm{~mL})\end{array}$ & $\begin{array}{l}7.1-10 \\
68-465 \\
50-444 \\
231-2950 \& 48-472 \\
1.1-40.3 \& \text { ND-> } 171 \\
200.5-7 \times 10^{5} \& \\
50-1.4 \times 10^{3}\end{array}$ \\
\hline Kitchen & $5-11$ & $\begin{array}{l}\text { Food particles, } \\
\text { cooking oils, greases, } \\
\text { detergents and other } \\
\text { cleaning products } \\
\text { such as dishwashing } \\
\text { powders }\end{array}$ & $\begin{array}{l}\text { - Fats which cannot be } \\
\text { broken can build up in the } \\
\text { soil and repel water } \\
\text { - Contaminants build up in } \\
\text { soils, vegetation and } \\
\text { groundwater }\end{array}$ & $\begin{array}{l}\mathrm{pH} \\
\text { TSS (mg/L) } \\
\text { Turbidity (NTU) } \\
\text { COD \& BOD (mg/L) } \\
\text { TN \& TP }(\mathrm{mg} / \mathrm{L}) \\
\text { Total coliforms \& faecal } \\
\text { coliforms }(\mathrm{CFU} / 100 \mathrm{~mL})\end{array}$ & $\begin{array}{l}5.9-7.4 \\
134-1300 \\
298 \\
26-2050 \& 536-1460 \\
11.4-74 \& 2.9->74 \\
-\end{array}$ \\
\hline
\end{tabular}

${ }^{\mathrm{a}}$ Modified from Christova-Boal et al., (1996); Water Corporation, (2008); Li et al., (2009). 


\section{PHYSICAL RISK}

According to Table 1, the turbidity of greywater varies greatly as a result of different household living habits. Caution must be taken if the high strength greywater is going to be reused since undissolved soils (e.g., hair, sand and clay) and suspended solids (e.g., fats and oils) can cause clogging of the distribution system. Another noteworthy physical risk is the sulphide, which will give offensive odours thereby causing public nuisance.

\section{CHEMICAL RISK}

The major potential chemical risks are posed by chemical pollutants and xenobiotic organic compounds (XOCs) from soaps, detergents and personal care products. It is clear that the build-up of these chemical compounds can have adverse effects to soil, vegetation and groundwater. Moreover, some chemicals such as endocrine disrupting compounds (EDCs) and pharmaceutical active compounds (PhACs) which used for health care are synthetic and their effects are only known partially. Thus, the potential risks are sometimes underestimated (Eriksson et al., 2002).

\section{MICROBIAL RISK}

Faecal contamination is common in greywater. Any of the coliform bacteria can pose potential risks of certain diseases to human, particularly in susceptible individuals such as the elderly, young and immunocompromised. Birks et al. (2004) conducted a microbiological study at Millennium Dome Greywater Reuse Project in UK and detected faecal oral transmitted Cryptosporidium and Giardia as well as E.coli, Legionella pneumophila 2-14 and faecal enterococci in hand basin greywater samples. Winward et al. (2008) found two opportunistic pathogens named Pseudomonas aeruginosa and Staphylococcus aureus in greywater in 2004, which can cause respiratory and skin infections. In addition, the regrowth 
of bacteria in greywater has also been investigated in some studies. Rose et al. (1991) observed the increase of the total aerobic count, coliform and faecal coliform bacteria between 1 and $2 \log 10$ units in stored untreated greywater (e.g., shower/bath and clothes washing streams) during the first 48 hours. Dixon et al. (1999) noticed the regrowth of total coliforms (TC) in stored bath grey water within 24 hours, from 1.7 to $>4.0 \log 10 \mathrm{cfu} \mathrm{mL} \mathrm{m}^{-1}$. Moreover, Gilboa and Friedler (2008) examined the regrowth potential of selected microorganisms in rotating biological reactor (RBC)-treated light greywater effluent and found that heterotrophic plate count (HPC) regrowth was statistically significant in undisinfected effluent and after irradiation with high UV doses (147 and $\left.439 \mathrm{~mW} \mathrm{~s} \mathrm{~cm}^{-2}\right)$. This phenomenon can be explained as a result of decreased competition with other bacteria at high UV doses.

Overall, greywater is relatively less polluted and low in contaminating pathogens, nitrogen, suspended solids and turbidity compared with other sources of recycled water (Eriksson et al., 2002). It can be efficiently reused for toilet flushing, landscape and garden irrigation, recreational impoundments watering, clothes washing, as well as fire protection (Pidou et al., 2008). Despite low health risk and no reported incidence of illness regarding greywater reuse, risk studies on this aspect are still limited and need to be further discussed (Winward et al., 2008).

\section{Municipal Wastewater}

Municipal wastewater is the largest and most significant source for water reuse around the world together with thousands of recycling schemes. Since many countries do not have extra pipelines, greywater, black water, industrial water and other waste streams from hospitals and commercial facilities are all discharged into municipal sewage systems. Therefore, municipal 
wastewater often contains a broad spectrum of contaminants that can be potential risks to human health and the environment (United Nations (UN), 2003; Shatanawi et al., 2007).

\section{PHYSICAL RISK}

Physical hazards such as wood and glass chips, metal fragments, undissolved and suspended solids from raw wastewater can cause blocking and clogging problems. Due to aesthetic concerns, other parameters such as $\mathrm{pH}$, total dissolved solids (TDS), total hardness and turbidity are also fairly important to recycling schemes, especially the ones with potential close human contact (New South Wales Food Authority (NSWFA), 2008).

\section{CHEMICAL RISK}

Chemical hazards of municipal wastewater consist of a wide range of naturally occurring and synthetic organic and inorganic species. Some key-class chemicals of concern are listed in Table 2 . The risks presented by those chemicals are variable. Some chemicals maybe acutely toxic that can exhibit toxic effects in a short period of time subsequent to a single significant dose, whereas others may be chronic that can have a cumulative effect on human health after exposing to small doses for long periods (Khan and Roser, 2007). Many common ions (e.g., sodium, potassium, calcium, chloride and bromide) may be of particular concern for reuse application such as agricultural and landscape irrigation, because highly saline irrigation water can severely degrade soils over time. Additionally, if recycled water is going to be treated for IPR or DPR, chronic effects are actually of greater importance and need to be carefully considered (O'Toole et al., 2007). For instance, trace organic contaminants such as EDCs, natural and synthetic hormones are shown to induce biological effects on some organisms at part per trillion concentrations (Weber et al., 2006). These chemicals-of-concern could also be a risk to the natural environment such as rivers, lakes and soils because of the 
accumulation effect. Besides, as the limited toxicological and epidemiological data on newly emerged synthetic, pharmaceutical and/or radioactive compounds, some potential risks are still unknown (Rodriguez et al., 2009). Nevertheless, some studies have pointed out that due to the very low concentrations and small possible effective doses of chemicals-of-concern in recycled water, even if the community are exposed to large volumes of recycled water or have heavily contact with it, the potential human health impacts are minimal (Toze, 2006a). 
Table 2. Major chemical constituents in municipal wastewater ${ }^{\mathrm{a}}$

\begin{tabular}{|c|c|c|c|}
\hline Sources & Category & Major compounds of concerns & Major risks and diseases \\
\hline \multirow{3}{*}{$\begin{array}{l}\text { Industrial } \\
\text { wastewater }\end{array}$} & Heavy metals & Cadmium, chromium, mercury and zinc & $\begin{array}{l}\text { Toxic and carcinogenic to humans, aquatic animals and } \\
\text { a number of plants }\end{array}$ \\
\hline & Synthetic industrial chemicals & $\begin{array}{l}\text { Plasticisers, heat stabilisers, biocides, epoxy } \\
\text { resins, bleaching chemicals and by-products, } \\
\text { solvents, degreasers, dyes, chelating agents, } \\
\text { polymers, polyaromatic hydrocarbons, } \\
\text { polychlorinated biphenyls and phthalates }\end{array}$ & Toxic to a diverse range of organisms and humans \\
\hline & Volatile organic compounds & $\begin{array}{l}\text { Petrochemical products, halogenated } \\
\text { compounds }\end{array}$ & Teratogenic or carcinogenic to humans \\
\hline \multirow{4}{*}{$\begin{array}{l}\text { Domestic } \\
\text { wastewater }\end{array}$} & Ammonium and organic loads & Ammonium & Can impact on aquatic systems \\
\hline & Antiseptics & Triclosan & Toxic to a diverse range of aquatic organisms \\
\hline & Hydraulic loading & Water & Waterlogging of plants and further soil salinity \\
\hline & Salinity and sodicity & $\begin{array}{l}\text { Calcium sulphates, magnesium, sodium } \\
\text { chloride }\end{array}$ & $\begin{array}{l}\text { Degrade soils and adverse effects on freshwater plants } \\
\text { and invertebrates in natural ecosystems }\end{array}$ \\
\hline \multirow{4}{*}{$\begin{array}{l}\text { Domestic } \\
\text { wastewater, } \\
\text { industrial } \\
\text { wastewater (e.g., } \\
\text { food processing } \\
\text { and/or medical } \\
\text { discharges) }\end{array}$} & Boron & Boron & $\begin{array}{l}\text { Can cause plant toxicity in some sensitive plant species } \\
\text { in some soils }\end{array}$ \\
\hline & Nutrients & $\begin{array}{l}\text { Eutrophication; Algal toxins such as } \\
\text { microcyctins, nodularins, } \\
\text { cylindrospermopsin and saxitoxins; Nitrates } \\
\text { leachate }\end{array}$ & $\begin{array}{l}\text { Toxic, hepatotoxic or neurotoxic to organisms, humans } \\
\text { and water bodies }\end{array}$ \\
\hline & Radionuclides & Radium and other compounds & Carcinogenic and mutagenic to organisms and humans \\
\hline & $\begin{array}{l}\text { Pharmaceuticals and natural } \\
\text { steroidal hormones }\end{array}$ & $\begin{array}{l}\text { Drugs, PhACs, EDCs, oestradiol, oestrone } \\
\text { and testosterone }\end{array}$ & $\begin{array}{l}\text { Endocrinological abnormalities in aquatic speicies; } \\
\text { some effects are unknown }\end{array}$ \\
\hline $\begin{array}{l}\text { Chlorination, } \\
\text { ozonation }\end{array}$ & Disinfection by-products & $\begin{array}{l}\text { Formaldehyde, bromate, epoxides and } \\
\text { nitrosodimethylamine (NDMA) }\end{array}$ & Harmful or toxic to plants, aquatic biota and humans \\
\hline $\begin{array}{l}\text { Stormwater influx } \\
\text { or illegal disposal }\end{array}$ & Pesticides & Non-degradable pesticides & Detrimental to a wide range of biological species \\
\hline
\end{tabular}

${ }^{a}$ Modified from Salgot et al., (2003); NRMMC-EPHC-AHMC, (2006); Khan and Roser, (2007); Stevens et al., (2008). 


\section{MICROBIAL RISK}

Similar to some chemicals, the pathogenic microorganisms associated with the reuse of wastewater are the primary health threat (Kamizoulis, 2008). From microbiological aspects, the main groups in municipal wastewater are excreted organisms and pathogens from human and animal origins. If the content of the causative pathogens increases to a certain amount, the disease will be likely to outbreak. Table 3 gives typical pathogens in municipal wastewater together with their concentrations, infectious doses and possible incurred diseases. Enteric viruses and protozoan pathogens are significantly more infectious than other bacterial pathogens. It was reported that the infectious dose of enteric viruses and protozoa can be as few as 10 viral particles or cysts, whereas only a high dose injection of enteric bacteria can cause infection in susceptible hosts. Helminth parasites also bring about a significant health risk and infection levels are particularly endemic, especially when agriculture and aquaculture using excreta containing wastewater. Peasey et al. (2000) reported that in Mexico, there was a higher prevalence of Ascaris infection in farmers and their children who worked and played in fields irrigated with untreated sewage effluent than who did not. In addition, the helminths have a simple life-cycle with no intermediate hosts and are capable of causing infection via the faecal-oral route (Toze, 2006a). Since the detention of all pathogens in recycled water is difficult and expensive, the representative microorganisms including Ecoli, total coliform, Enterococci, Giardia, Campylobacter and Cryptosporidium are commonly used as indicators to determine the possible presence of pathogens in a sample (Toze, 1997; Khan and Roser, 2007). 
Table 3. Typical pathogens in municipal wastewater ${ }^{\mathrm{a}}$

\begin{tabular}{|c|c|c|c|c|}
\hline Microbial type & Organisms & $\begin{array}{l}\text { Numbers in wastewater } \\
\text { (per L) }\end{array}$ & Infectious dose & Major risks and diseases \\
\hline \multirow{6}{*}{ Bacteria } & Thermotolerant coliforms & $10^{8}-10^{10}$ & High & General diarrhoea \\
\hline & E.coli & $10^{7}-10^{9}$ & High & $\begin{array}{l}\text { Gastroenteritis, sepsis, wound infection, } \\
\text { urinary tract and respiratory tract infections }\end{array}$ \\
\hline & Campylobacter jejuni & $10-10^{4}$ & $10^{6}$ & Gastroenteritis \\
\hline & Salmonella typhi & $1-10^{5}$ & $10^{4}-10^{7}$ & Typhoid, salmonellosis \\
\hline & Shigella dysenteriae & $10-10^{4}$ & $10-100$ & Dysentery \\
\hline & Vibrio cholerae & $10^{2}-10^{5}$ & $10^{3}-10^{7}$ & Cholera \\
\hline \multirow{3}{*}{$\begin{array}{l}\text { Intestinal } \\
\text { helminths }\end{array}$} & Ascaris lumbricoides & $1-10^{3}$ & $1-10$ & Ascariasis (roundworm infection) \\
\hline & Ancylostoma/Necator & $1-10^{3}$ & Low & $\begin{array}{l}\text { Ancylostomiasis/ Necatoriasis (hookworm/ } \\
\text { roundworm infection) }\end{array}$ \\
\hline & Trichuris trichiura & $1-10^{2}$ & 1 & Trichuriasis (whipworm infection) \\
\hline \multirow{3}{*}{ Protozoa } & Cryptosporidium parvum & $1-10^{4}$ & $1-10$ & Diarrhoea, fever \\
\hline & Entamoeba histolytica & $1-10^{2}$ & $10-100$ & Amoebic dysentery \\
\hline & Giardia intestinalis & $10^{2}-10^{5}$ & $25-100$ & Giardiasis \\
\hline \multirow{2}{*}{ Viruses } & Enteric viruses & $10^{5}-10^{6}$ & $1-10$ & $\begin{array}{l}\text { Poliomylitis, gastroenteritis, heart anomalies, } \\
\text { meningitis and hepatitis }\end{array}$ \\
\hline & Rotavirus & $10^{2}-10^{5}$ & $1-10$ & Gastroenteritis \\
\hline
\end{tabular}

${ }^{\mathrm{a}}$ Modified from Toze, (1997); Jimenez, (2003); Gundry et al., (2004); U.S. EPA, (2004); Kamizoulis, (2008). 


\section{Industrial Wastewater}

Industrial wastewater is defined as effluents that result from human activities which are related to raw material processing and manufacturing (Jern, 2006). The composition of industrial wastewater varies considerably owing to different industrial activities. Even within a single type of industry, specific processes and chemicals used to produce similar products can differ, which leads to significant changes in wastewater characteristics over time. Table 4

illustrates typical wastewater compositions in several industries (Wang et al., 2004; Bielefeldt, 2009). 
Table 4. Examples of typical industrial wastewater characteristics ${ }^{\mathrm{a}}$

\begin{tabular}{|c|c|c|c|c|c|c|c|}
\hline Wastewater type & $\begin{array}{l}\text { Average } \mathrm{pH} \\
\text { range }\end{array}$ & $\begin{array}{l}\text { Suspended } \\
\text { solids }(\mathrm{mg} / \mathrm{L})\end{array}$ & $\mathrm{BOD}_{5}(\mathrm{mg} / \mathrm{L})$ & COD (mg/L) & TKN (mg N/L) & Total P (mg/L) & Salt $(\mathrm{g} / \mathrm{L})$ \\
\hline Allopathic medicines & $6.5-7$ & $300-400$ & $1200-1700$ & $2000-3000$ & - & - & - \\
\hline Brewery & $3.3-7.6$ & $500-3000$ & $1400-2000$ & $815-12500$ & $14-171$ & $16-124$ & - \\
\hline $\begin{array}{l}\text { Dairy milk-cheese } \\
\text { plants }\end{array}$ & $5.2-11.3$ & $350-1082$ & $709-10000$ & $189-20000$ & $14-450$ & $37-78$ & 0.5 \\
\hline Dairy parlour & $2-11$ & $100-300$ & $166-477$ & $470-820$ & $25-45$ & $17-21$ & $0.05-0.7$ \\
\hline Dying & $8.2-12$ & $56-70$ & $140-840$ & $70-3200$ & $27-42$ & $5-7$ & - \\
\hline Food pickling & $2.6-3$ & $40-110$ & $7000-8000$ & $20000-22000$ & $4-6$ & $22-25$ & $30-150$ \\
\hline Metal working fluids & 9 & - & $1500-11400$ & $5300-40000$ & $160-440$ & $28-77$ & - \\
\hline Pharmaceutical & $5.5-9.2$ & $30-55$ & - & $1200-7000$ & $80-500$ & $3.5-35$ & - \\
\hline Potato processing & - & $280-420$ & - & $1100-3100$ & $95-145$ & $10-15$ & - \\
\hline Pulp and paper & $6.6-10$ & $21-1120$ & $77-1150$ & $100-3500$ & $1-3$ & $1-3$ & 0.05 \\
\hline $\begin{array}{l}\text { Synthetic drug } \\
\text { medicine }\end{array}$ & $2.9-7.6$ & - & $1840-2835$ & $4000-5194$ & - & - & - \\
\hline Tannery & $8-11$ & $2070-4320$ & $1000-7200$ & $3500-13500$ & $250-1000$ & $4-107$ & $6-40$ \\
\hline Textile mills & $4.5-10.1$ & $20-210$ & $700-1650$ & $1900-100000$ & $14-72$ & $1-18$ & $0.5-0.9$ \\
\hline Winery & $3.9-5.5$ & $170-1400$ & $210-8000$ & $320-27200$ & $21-64$ & $16-66$ & $0.1-1$ \\
\hline Municipal & $6-8$ & $6-8$ & $110-400$ & $250-1000$ & $20-85$ & $4-15$ & $<0.5$ \\
\hline
\end{tabular}

${ }^{\mathrm{a}}$ Modified from Bielefeldt, (2009). 


\section{PHYSICAL RISK}

As can be seen from Table 4, some types of industrial wastewaters (e.g., dairy parlour and dying wastewaters) may be caustic, with extreme $\mathrm{pH}$ of $<2$ or $>12$. Without buffering to more neutral conditions, these extreme $\mathrm{pH}$ values would be inhibitory to microorganisms. Moreover, wastewaters from food processing industries (e.g., potato, olive oil and meat processing) can introduce nuisances and inhibit the transfer of oxygen from atmosphere to water, owing to the insolubility of oil and grease in water. Additionally, wastewaters with extreme temperatures (e.g., cooling, metal working and refinery wastewaters) can reduce the dissolved oxygen content and affect metabolism of aquatic creatures thereby declining water quality and decreasing biodiversity (Jern, 2006; Bielefeldt, 2009).

\section{CHEMICAL RISK}

In addition to bulk chemical constituents, a significant excess of nutrients (e.g., nitrogen $(\mathrm{N})$ and phosphorus (P)) may be present in some industrial wastewaters (e.g., pectin, pharmaceutical and tannery), which become potential threats to water bodies due to cultural eutrophication. On the other hand, the limitation of nutrients (such as $\mathrm{N}$ limitation in brewery wastewater, $\mathrm{P}$ limitation in pulp and paper wastewater, and $\mathrm{N}$ and $\mathrm{P}$ limitation in winery wastewater) also pose potential problems to biological treatment. In addition, some industrial wastewaters may be rich in high concentrations of organic compounds and salts (e.g., food pickling and tannery wastewaters), as well as specific toxic substances (e.g., tin, lead and nickel) in printed circuit board (PCB) manufacturing wastewater, silver and ferrocyanide in photographic operation wastewater, chromium compounds and cadmium sulphide in pigment manufacturing wastewater) (Barakat, 2010). Minhas and Samra (2004) reported the transfer of metal ions from wastewater to cow's milk through Para grass fodder irrigated by wastewater along the Musi River in India. The analysis results from milk samples revealed 
that the concentrations of metal ions such as $\mathrm{Cd}, \mathrm{Cr}, \mathrm{Ni}, \mathrm{Pb}$ and $\mathrm{Fe}$ are 12 to 40 times higher than permissible levels. Heavy metals are not only significant threats to human and the environment, but also can change redox state during biological treatment. To help hazard classification and assessment, some toxicity scores and final wastewater toxicity indexes regarding industrial effluents have been developed. For instance, Tonkes et al. (1999) recommended a four-toxicity-class system which is based on a percentage effect wastewater volume $(\mathrm{w} / \mathrm{v})$ ranking, considering the effect concentration of organism towards the strongest response at $50 \%$ (EC50) value as endpoint $(<1 \% \mathrm{w} / \mathrm{v}=$ very acutely toxic; $1-10 \%$ $\mathrm{w} / \mathrm{v}=$ moderately acutely toxic; $10-100 \% \mathrm{w} / \mathrm{v}=$ minor acutely toxic; and $>100 \%=$ not acutely

toxic). Similarly, others proposed different wastewater classification approaches on the basis of various weighting methods (Vindimian et al., 1999; Persoone et al., 2003; Libralato et al., 2010). As a result, the toxicity scores and/or indexes can provide suggestions to wastewater recycling and reuse. When toxicity is absent, no action is necessary to further improve the wastewater quality at the discharge, and it could be possible to reuse effluent for non-potable purposes. Otherwise, if some actions must be undertaken to improve the effluent, toxicity outcomes can help to support the implementation of the best available technologies for wastewater treatment (Libralato et al., 2010). Furthermore, although some chemicals such as methanol, ammonia, benzene, etc. are relatively less toxic, the uncontrolled release of these substances into sewers or the environment can disrupt treatment or ecology (Bielefeldt, 2009). The risks of different industrial wastewaters are summarized in Table 2.

\section{MICROBIAL RISK}

Some industrial wastewaters (e.g., food processing, dairy milk and winery wastewaters) contain extreme high quantity of microorganisms which can cause microbial risks to human health and the environment (Jern, 2006). Moreover, microorganisms carrying antibiotic- 
resistant genes can affect the biological treatment efficiency by competing against the wastedegrading bacteria (Bielefeldt, 2009). Pathogen regrowth and evolution in industrial wastewater is also a potential trouble. Casani et al. (2005) reported the growth of a psychrotrophic bacterial pathogen, Listeria monocytogenes, in cool damp treated food industry wastewater. The microorganism even transferred to other pathogens such as Legionella. In general, pathogenic microorganisms generally pose greater risks to human health than chemicals, whereas chemicals normally have higher risks to the environment than microbial hazards (NRMMC-EPHC-AHMC, 2006). As such, from the standpoint of public health, microbial risk becomes the prime concern in water reuse studies (Diaper, 2001; Toze, 2006b).

\section{RISK CONTROL ON WASTEWATER}

To ensure water reuse in a safe, acceptable, reliable and aesthetical way, it is indispensable to conduct risk control to reduce the risk level to corresponding guideline values (Qadir et al., 2010; Winward et al., 2008). Risk control approaches include source control, recycled water quality improvement, critical point control and exposure control (Stevens et al., 2008).

\section{Source Control}

Source control and hazard prevention are proved to be important to avoid potential risks to some extent. In particular, restricting the discharge of some chemicals into municipal wastewater systems can significantly reduce the chronic toxic potential to the environment. For example, South East Queensland, Australia has conducted a source control process to ensure a high quality of purified recycled water. If a sewage system is provided primarily for transporting and treating domestic sewage, an approval must be needed before discharging trade waste into water reclamation plant through sewage system (Corre, 2011). Currently, 
more sewage treatment plants have reached an agreement with industries to prevent trade waste and other hazards entering the sewage system (NRMMC-EPHC-AHMC, 2006).

\section{Recycled Water Quality Improvement}

The quality of recycled water determines the options for reuse. The higher the quality, the more reuse options are available (Higgins et al., 2002). Currently, excessive dissolved solids and toxic compounds have been increasingly detected in wastewater due to the economic and social development. Insufficient or improper wastewater treatment can cause the accumulation of dissolved compounds as well as non-degradable substances in the soil media, surface water and groundwater, thus, affecting human health and sustainable environmental development (Oron et al., 2007). In many developing countries, primary treated effluent is commonly used for irrigation (Mara, 2003). In some areas, secondary treatments such as wastewater stabilization ponds, constructed wetlands (CWs), infiltrationpercolation and up-flow anaerobic sludge blanket reactors are also implemented at reasonable cost. However, the treated water may still pose microbial risk. A World Health Organization (WHO) report demonstrated that crop irrigation with untreated wastewater could cause significant infection of field workers and crop consumers with intestinal nematode while adequately treated wastewater would not result in any adverse effect (Blumenthal et al., 2000; WHO, 2006). Trang et al. (2006) also reported that farmers irrigating with wastewater had higher rates of helminth infection than farmers using freshwater. Therefore, selecting appropriate technologies for wastewater of different origins is crucial, which should be complied with national or local water quality guidelines in terms of particular end uses. Table 5 illustrates the performance of different treatment stages for microbial pathogen removal. Normally, microbial risk levels can be reduced to at least one to six orders of magnitude through adequate treatment. To secure treated water quality, more advanced treatment 
technologies such as microfiltration (MF), ultrafiltration (UF), nanofiltration (NF), reverse osmosis (RO) and membrane bioreactor (MBR) have been actively developed, especially in severe water stressing regions.

Tables 6-9 summarize some pilot and case studies on wastewater treatment for different end uses. As shown in Table 6, the treated effluent from low strength grey water processed by physical and chemical treatment are suitable for either restricted or unrestricted non-potable uses under safe condition, depending on different water reuse standards (Li et al., 2009). This technology is widely used at small scale residences which can possibly reduce $30-35 \%$ fresh water consumption (Diaper et al., 2001; Pidou et al., 2008). Comparatively, for medium and high strength greywater, biological treatment processes such as rotating biological contactor (RBC), CWs or MBR are often needed, which can achieve higher removal efficiency (Table 7) (Li et al., 2009). Although MBR has the highest performance, the system becomes economically feasible only if the building size exceeded 40 storeys (Friedler and Hadari, 2006). For water reuse in large buildings, physical processes (e.g., sedimentation and screening) combined with biological processes and disinfection are also reported widely (Santala et al., 1998). For instance, a greywater demonstration project in Chengdu Medical College, China, employs coagulation, sedimentation, Biological aerated filter (BAF), sand filter and disinfection processes for greywater treatment at student dormitories. The treated effluent is able to meet the Chinese urban mixed water quality standards specified for urban water reuse and can be used for landscape irrigation, road sprinkle and supplementary of the artificial lake (Qiang et al., 2008). Another study conducted at Millennium Dome, UK, revealed that greywater treated by BAF can achieve a range of 0-5 log removal for both total coliforms and E.coli (Table 7). Nevertheless, to meet the water reuse guidelines in toilet flushing, BAF should be coupled with UF and RO processes (Birks et al., 2004). 
Table 5. Microbial pathogen removal by selected treatment processes ${ }^{\mathrm{a}}$

\begin{tabular}{|c|c|c|c|c|c|c|c|c|c|c|}
\hline \multirow{2}{*}{$\begin{array}{l}\text { Treatment technologies } \\
\text { (barriers) }\end{array}$} & \multicolumn{10}{|c|}{ Pathogen removal } \\
\hline & \multicolumn{2}{|c|}{$\begin{array}{l}\text { Total coliform } \\
\text { (Percentage and log } \\
\text { reduction) }\end{array}$} & $\begin{array}{l}\text { Faecal coliform } \\
\text { (log reduction) }\end{array}$ & \multicolumn{2}{|c|}{$\begin{array}{l}\text { Helminths } \\
\text { (Percentage and log } \\
\text { reduction) }\end{array}$} & \multicolumn{2}{|c|}{$\begin{array}{l}\text { Protozoa } \\
\text { (Percentage and log } \\
\text { reduction) }\end{array}$} & \multicolumn{2}{|c|}{$\begin{array}{l}\text { Viruses } \\
\text { (Percentage and log } \\
\text { reduction) }\end{array}$} & $\begin{array}{l}\text { Phage } \\
\text { (log reduction) }\end{array}$ \\
\hline \multicolumn{11}{|l|}{ Primary treatment } \\
\hline Sedimentation & $50-90$ & $0-1$ & - & 90 & $0-1$ & $27-64$ & $0-1$ & $50-98$ & $0-1$ & - \\
\hline $\begin{array}{l}\text { Sedimentation }+ \text { chemical } \\
\text { coagulation }\end{array}$ & $50-90$ & $0-1$ & - & $90-99.9$ & $1-3$ & $27-90$ & $0-1$ & $50-98$ & $0-1$ & - \\
\hline \multicolumn{11}{|l|}{ Secondary treatment } \\
\hline $\begin{array}{l}\text { Activated sludge or tricking } \\
\text { filter }+ \text { secondary } \\
\text { sedimentation }\end{array}$ & $90-99.9$ & $1-3$ & 2.5 & $90-99.9$ & $1-2$ & $45-97$ & $0-1$ & $53-99$ & $0-3$ & $1.6-6.6$ \\
\hline Aerated lagoon + settling pond & $90-99.9$ & $1-2$ & - & $90-99.9$ & $1-3$ & $45-97$ & $0-1$ & $90-99$ & $1-2$ & $0.11-0.39$ \\
\hline \multicolumn{11}{|l|}{ Tertiary treatment } \\
\hline Coagulation/flocculation & $30-90$ & $0-1$ & - & 99 & 2 & $95-99$ & $1.5-4$ & $90-99.9$ & $1-3$ & - \\
\hline Sand filtration & $50-99.5$ & $0-2.5$ & - & $90-99$ & $1-2$ & $50-99.9$ & $0-3$ & $20-99.99$ & $0.5-3$ & - \\
\hline Media filtration & $30-90$ & $0-1$ & - & $99-99.9$ & $2-3$ & $90-99.9$ & $1-3$ & $50-99.9$ & $0.5-3$ & - \\
\hline \multicolumn{11}{|l|}{ Quaternary treatment } \\
\hline Membrane filtration & $>99.9999$ & $3.5-6$ & 7 & $>99.9$ & $>3$ & $>99.9999$ & $>6$ & $>99.9999$ & $2.5-6$ & $>6$ \\
\hline \multicolumn{11}{|l|}{ Disinfection } \\
\hline Chlorination & 98-99.9999 & $2-6$ & 3 & $<90$ & $0-1$ & $<95$ & $0-1.5$ & $90-99$ & $1-3$ & 3 \\
\hline Ozonation & $99-99.9999$ & $2-6$ & $2-3$ & $<90$ & $0-1$ & $90-99$ & $1-2$ & $\begin{array}{l}99.9- \\
99.9999\end{array}$ & $3-6$ & $2-6$ \\
\hline Ultraviolet disinfection & $99-99.99$ & $2-4$ & $2-3.5$ & - & & $>99.9$ & $>3$ & $90-99.9$ & $1-3$ & $4-6$ \\
\hline
\end{tabular}

${ }^{\mathrm{a}}$ Modified from Toze, (2006a); Environmental Protection and Heritage Council (EPHC), (2008); Kamizoulis et al., (2008). 
Table 6. Low strength greywater (e.g., laundry and showering wastewater) quality improvement and reuse through selected treatment processes

\begin{tabular}{|c|c|c|c|c|c|c|}
\hline \multirow{2}{*}{ Treatment processes (barriers) } & \multicolumn{4}{|c|}{ Removal rate $(\%)$} & \multirow{2}{*}{ Reuse applications } & \multirow{2}{*}{ References } \\
\hline & $\mathrm{BOD}_{5}$ & COD & TSS & Turbidity & & \\
\hline $\begin{array}{l}\text { Screening }+ \text { Sedimentation+ } \\
\text { Disinfection }\end{array}$ & - & 54 & 56.8 & 15 & $\begin{array}{l}\text { Cannot meet non-potable reuse guidelines } \\
\text { in terms of physical, chemical and } \\
\text { microbiological parameters }\end{array}$ & March et al., (2004) \\
\hline UF & 56 & 54 & 49 & - & $\begin{array}{l}\text { UF cannot meet non-potable reuse } \\
\text { guidelines in terms of BOD removal }\end{array}$ & \\
\hline $\mathrm{RO}$ & 98 & 97.7 & 56 & - & Non-potable applications & $\begin{array}{l}\text { Sostar-Turk et al., } \\
(2005)\end{array}$ \\
\hline Electro-coagulation+ Disinfection & 61 & 58 & 69 & 91 & $\begin{array}{l}\text { Cannot meet non-potable reuse guidelines } \\
\text { in terms of turbidity and pathogen removal }\end{array}$ & \\
\hline \multicolumn{5}{|c|}{$\begin{array}{l}\text { Screening }+ \text { Sedimentation }+ \text { Coagulation }+ \text { MF or Screening }+ \\
\text { Sedimentation }+ \text { Coagulation }+ \text { Sand filtration }+ \text { Disinfection }\end{array}$} & Unrestricted non-potable urban uses & Li et al., (2009) \\
\hline \multicolumn{5}{|c|}{ Screening + Sedimentation + Coagulation + Sand filtration } & Restricted non-potable urban uses & \\
\hline
\end{tabular}

Abbreviation: $\%=$ percentage removal; $\mathrm{BOD}_{5}=$ Biological Oxygen Demand; COD $=$ Chemical Oxygen Demand; TSS $=$ Total Suspended Solids; UF = Ultrafiltration; RO = Reverse Osmosis. 
Table 7. High strength greywater (e.g., kitchen wastewater) quality improvement and reuse through selected treatment processes

\begin{tabular}{|c|c|c|c|c|c|c|c|c|c|c|c|}
\hline \multirow{2}{*}{$\begin{array}{l}\text { Treatment } \\
\text { processes } \\
\text { (barriers) }\end{array}$} & \multicolumn{4}{|c|}{ Removal rate $(\%)$} & \multicolumn{5}{|c|}{ Log reduction } & \multirow{2}{*}{$\begin{array}{l}\text { Reuse } \\
\text { applications }\end{array}$} & \multirow[b]{2}{*}{ References } \\
\hline & $\mathrm{BOD}_{5}$ & COD & TSS & Turbidity & $\mathrm{TC}$ & E.coli & Enterococci & Clostridia & $\begin{array}{l}\mathrm{P} . \\
\text { aeruginosa }\end{array}$ & & \\
\hline BAF & - & - & - & - & $6-7$ & $5-6$ & $4-5$ & - & - & $\begin{array}{l}\text { Toilet flushing } \\
\text { at the } \\
\text { Millennium } \\
\text { Dome, London }\end{array}$ & $\begin{array}{l}\text { Birks et al., } \\
(2004)\end{array}$ \\
\hline $\begin{array}{l}\text { Horizontal flow } \\
\text { reed bed }\end{array}$ & 65 & 75 & 63 & 82 & 3 & 1.1 & 1.7 & 1.3 & 3 & Non-potable & Winward et al., \\
\hline $\begin{array}{l}\text { Vertical flow } \\
\text { reed bed }\end{array}$ & 97 & 94 & 89 & 97 & 3.1 & 1.5 & 2.3 & 2 & 3.8 & applications & $(2008)$ \\
\hline $\mathrm{RBC}$ & 96 & 75 & 82 & 98 & 5 & - & - & - & - & $\begin{array}{l}\text { Non-potable } \\
\text { applications }\end{array}$ & $\begin{array}{l}\text { Friedler et al., } \\
(2005)\end{array}$ \\
\hline $\mathrm{RBC}+\mathrm{UV}$ & 96.1 & 47.7 & - & 95.5 & 2 & - & - & - & 1 & Toilet flushing & $\begin{array}{l}\text { Friedler and } \\
\text { Gilboa, (2010) }\end{array}$ \\
\hline MBR & 99 & 89 & 99 & 99.7 & 6.8 & 3.8 & 2.7 & 2.6 & 6.7 & $\begin{array}{l}\text { Non-potable } \\
\text { applications }\end{array}$ & $\begin{array}{l}\text { Winward et al., } \\
(2008)\end{array}$ \\
\hline MBR & 98.8 & 51.2 & - & 99.4 & 6 & - & - & - & 4 & Toilet flushing & $\begin{array}{l}\text { Friedler and } \\
\text { Gilboa, (2010) }\end{array}$ \\
\hline
\end{tabular}


Table 8. Municipal wastewater quality improvement and reuse through selected treatment processes

\begin{tabular}{|c|c|c|c|c|c|c|c|c|c|c|c|}
\hline \multirow{2}{*}{$\begin{array}{l}\text { Treatment } \\
\text { processes } \\
\text { (barriers) }\end{array}$} & \multicolumn{8}{|c|}{ Treated Water quality (\% removal) } & \multirow{2}{*}{ Comments } & \multirow{2}{*}{$\begin{array}{l}\text { Reuse } \\
\text { application }\end{array}$} & \multirow{2}{*}{ References } \\
\hline & TSS & Turbidity & $\mathrm{BOD}_{5}$ & COD & $\mathrm{TN}$ & $\mathrm{TP}$ & $\mathrm{TC}$ & $\mathrm{FC}$ & & & \\
\hline $\begin{array}{l}\text { Sec. + UF+ RO } \\
\text { or Sec. + AC }\end{array}$ & \multicolumn{8}{|c|}{$\begin{array}{l}\text { Removal of some toxicants } \\
\text { (toxicity study on Japanese medaka) }\end{array}$} & $\begin{array}{l}\text { MF and UF could not efficiently } \\
\text { remove trace toxicants and EDCs } \\
\text { while UF-RO and AC can remove } \\
\text { most of the toxicants and heavy } \\
\text { metals }\end{array}$ & $\begin{array}{l}\text { Aquaculture } \\
\text { and } \\
\text { environmental } \\
\text { uses }\end{array}$ & $\begin{array}{l}\text { Zha and } \\
\text { Wang, } \\
(2005)\end{array}$ \\
\hline Sec. + UF+ RO & 99.3 & - & 94.5 & 92 & 20.6 & 12.4 & - & 99.9 & $\begin{array}{l}\text { - UF can efficiently remove organic } \\
\text { matter and pathogens } \\
\text { - RO can efficiently remove } \\
\text { nutrients and dissolved solids }\end{array}$ & $\begin{array}{l}\text { Agricultural } \\
\text { irrigation in } \\
\text { Israel }\end{array}$ & $\begin{array}{l}\text { Oron et al., } \\
(2008)\end{array}$ \\
\hline Sec. + UF+ RO & - & - & - & - & 67 & 91.7 & 100 & - & $\begin{array}{l}\text { - UF could not efficiently remove } \\
\text { sodium and hardness } \\
\text { - The concentration of } \mathrm{N} \text { and } \mathrm{P} \\
\text { exceeds the effluent discharge } \\
\text { standards in Belgium, therefore, } \\
\text { reed beds are used }\end{array}$ & $\begin{array}{l}\text { Groundwater } \\
\text { recharge and } \\
\text { IPR in } \\
\text { Belgium }\end{array}$ & $\begin{array}{l}\text { Van } \\
\text { Houtte and } \\
\text { Verbauwh } \\
\text { ede, } \\
(2008)\end{array}$ \\
\hline $\begin{array}{l}\text { Sec. }+\mathrm{CF}+\mathrm{MF} \\
\text { (Coagulant } \\
\text { dose: } 50 \mathrm{mg} / \mathrm{l}) \\
\text { Sec. }+ \\
\text { Ozonation+ MF } \\
\text { (Ozone gas } \\
\text { dose: } 15 \mathrm{mg} / \mathrm{l}) \\
\end{array}$ & - & 82.3 & - & 71 & 32 & 100 & - & - & $\begin{array}{l}\text { - CF can efficiently remove turbidity } \\
\text { and TP while ozonation can } \\
\text { efficiently remove organic matter, } \\
\text { turbidity and DOC } \\
\text { - Both processes can meet the water } \\
\text { reuse guidelines proposed by } \\
\text { U.S.EPA and South Korea }\end{array}$ & $\begin{array}{l}\text { Agricultural } \\
\text { irrigation in } \\
\text { South Korea }\end{array}$ & $\begin{array}{l}\text { Park et al., } \\
(2010)\end{array}$ \\
\hline
\end{tabular}

Abbreviation: $\%=$ percentage removal; TSS = Total Suspended Solids; BOD $_{5}=$ Biological Oxygen Demand; COD = Chemical Oxygen Demand; TN $=$ Total Nitrogen; $\mathrm{TP}=$ Total Phosphorus; $\mathrm{TC}=$ Total Coliform; FC $=$ Faecal Coliform; Sec. $=$ Secondary treatment; UF $=$ Ultrafiltration; $\mathrm{RO}=$ Reverse Osmosis; $\mathrm{AC}=$ Activated Carbon; $\mathrm{EDCs}=$ Endocrine Disrupting Compounds; $\mathrm{CF}=\mathrm{Coagulation}-\mathrm{Flocculation} ; \mathrm{MF}=$ Microfiltration; DOC $=$ Dissolved Organic Carbon. 
Table 8. (continued)

\begin{tabular}{|c|c|c|c|c|c|c|c|c|c|c|c|}
\hline \multirow{2}{*}{$\begin{array}{l}\text { Treatment } \\
\text { processes } \\
\text { (barriers) }\end{array}$} & \multicolumn{8}{|c|}{ Treated Water quality (\% removal) } & \multirow{2}{*}{ Comments } & \multirow{2}{*}{ Reuse application } & \multirow{2}{*}{ References } \\
\hline & TSS & Turbidity & $\mathrm{BOD}_{5}$ & COD & $\mathrm{TN}$ & $\mathrm{TP}$ & $\mathrm{TC}$ & $\mathrm{FC}$ & & & \\
\hline Sec. + MF & 96.3 & 91.2 & 42.6 & 30 & 68.9 & 13.7 & 99.99 & 99.5 & $\begin{array}{l}\text { The MF product water } \\
\text { satisfied irrigation standards, } \\
\text { but chloride may cause a } \\
\text { moderate risk potential and } \\
\text { trace metals could be } \\
\text { accumulated and become } \\
\text { hazards unless other treatments }\end{array}$ & $\begin{array}{l}\text { Agricultural } \\
\text { irrigation in Kuwait }\end{array}$ & $\begin{array}{l}\text { Al- } \\
\text { Shammiri } \\
\text { et al., } \\
(2005)\end{array}$ \\
\hline $\begin{array}{l}\text { Sec. }+ \text { MF }+ \\
\text { RO }\end{array}$ & - & - & - & - & - & - & 100 & 100 & $\begin{array}{l}\text { MF+RO can produce high } \\
\text { quality treated water which } \\
\text { satisfies the Korean drinking } \\
\text { water standards due to } \\
\text { stringent irrigation } \\
\text { requirements }\end{array}$ & $\begin{array}{l}\text { Agricultural } \\
\text { irrigation on islands } \\
\text { in Korea }\end{array}$ & $\begin{array}{l}\text { Yim et al., } \\
(2007)\end{array}$ \\
\hline $\begin{array}{l}\text { Horizontal } \\
\text { flow CWs } \\
\text { (HF-CWs) }\end{array}$ & 68.1 & - & 80.7 & 63.2 & 39.4 & 40.9 & $3 \log$ & - & $\begin{array}{l}\text { HF-CWs can successfully treat } \\
\text { wastewaters with very low } \\
\text { concentrations of organics }\end{array}$ & $\begin{array}{l}\text { Environmental and } \\
\text { recreational uses in } \\
\text { Czech Republic }\end{array}$ & $\begin{array}{l}\text { Vymazal, } \\
(2009) ; \\
\text { Vymazal, } \\
(2002)\end{array}$ \\
\hline $\begin{array}{l}\text { Sec. }+ \text { CWs } \\
\text { (HRT } 16 \\
\text { days) }\end{array}$ & - & - & - & - & 92 & 26 & - & 98.7 & $\begin{array}{l}\text { CWs can efficiently reduce } \\
\text { nutrients, perform the function } \\
\text { of disinfection and restore } \\
\text { ecological systems }\end{array}$ & $\begin{array}{l}\text { Agricultural and } \\
\text { landscape irrigation } \\
\text { and environmental } \\
\text { uses in Queensland, } \\
\text { Australia }\end{array}$ & $\begin{array}{l}\text { Greenway, } \\
(2005)\end{array}$ \\
\hline
\end{tabular}

Abbreviation: Sec. $=$ Secondary treatment; $\mathrm{MF}=$ Microfiltration; RO $=$ Reverse Osmosis; CWs $=$ Constructed Wetlands; HRT $=$ Hydraulic Retention Time. 
Table 8. (continued)

\begin{tabular}{|c|c|c|c|c|c|c|c|c|c|c|c|}
\hline \multirow{2}{*}{$\begin{array}{l}\text { Treatment } \\
\text { processes } \\
\text { (barriers) }\end{array}$} & \multicolumn{8}{|c|}{ Treated Water quality (\% removal) } & \multirow{2}{*}{ Comments } & \multirow{2}{*}{$\begin{array}{l}\text { Reuse } \\
\text { application }\end{array}$} & \multirow{2}{*}{ References } \\
\hline & TSS & Turbidity & $\mathrm{BOD}_{5}$ & COD & $\mathrm{TN}$ & $\mathrm{TP}$ & $\mathrm{TC}$ & $\mathrm{FC}$ & & & \\
\hline $\begin{array}{l}\text { Tertiary }+ \\
\text { photocatalysis } \\
\left(\mathrm{TiO}_{2}\right)\end{array}$ & \multicolumn{8}{|c|}{$\begin{array}{l}\text { Removal of some EDCs (\%): } \\
\text { 17ß-Estradiol: 98; Malathion: 94; 3-Amino-2-chloropyridine: } 98 \text {; } \\
\text { Atrazine: 84.2; Diazinon: 99; Lindane: 99; } \\
\text { Bisphenol A: 85.7; Aldrin: 76.3; 2-4-Dichlorophenol: } 96 .\end{array}$} & $\begin{array}{l}\text { Photocatalysis can } \\
\text { efficiently remove EDCs } \\
\text { and microbial pathogens }\end{array}$ & $\begin{array}{l}\text { Agricultural } \\
\text { irrigation and } \\
\text { aquaculture in } \\
\text { Italy }\end{array}$ & $\begin{array}{l}\text { Meric and } \\
\text { Fatta, } \\
(2007)\end{array}$ \\
\hline $\begin{array}{l}\text { Tertiary }+ \\
\text { SAT }\end{array}$ & 100 & - & 99.8 & 99 & 99.9 & 99.1 & $5 \log$ & $7 \log$ & $\begin{array}{l}\text { Biological treatment can } \\
\text { efficiently remove } \\
\text { dissolved organic matter } \\
\text { and nitrogen while SAT } \\
\text { can efficiently remove } \\
\text { phosphorus, heavy metals } \\
\text { and trace elements }\end{array}$ & $\begin{array}{l}\text { Unrestricted } \\
\text { agricultural } \\
\text { irrigation in } \\
\text { Israel }\end{array}$ & $\begin{array}{l}\text { Arlosoroff, } \\
(2006)\end{array}$ \\
\hline MBR & \multicolumn{8}{|c|}{$\begin{array}{l}\text { Removal of some EDCs (\%): } \\
\text { 17ß-Estradiol: } 95.7-98.5 \text {; Nonylphenol ethoxylates: } 91-97 \text {; } \\
\text { Nonylphenol diethoxylate: } 97.8 \text {; Estron: } 96.3 ; \\
\text { Bisphenol A: } 92.7-99.9 ; 17 \alpha \text {-ethinylestradiol: } 92.4 \text {. }\end{array}$} & $\begin{array}{l}\text { MBR can efficiently } \\
\text { remove EDCs and DOC }\end{array}$ & $\begin{array}{l}\text { Agricultural } \\
\text { irrigation }\end{array}$ & $\begin{array}{l}\text { Lyko et al., } \\
(2005)\end{array}$ \\
\hline MBR & 99 & $98.8-100$ & $>97$ & $89-98$ & $36-80$ & $62-97$ & $5-8 \log$ & - & $\begin{array}{l}\text { MBR can efficiently } \\
\text { remove organics, nutrients } \\
\text { and microorganisms }\end{array}$ & $\begin{array}{l}\text { Industrial and } \\
\text { agricultural in } \\
\text { Italy and } \\
\text { France }\end{array}$ & $\begin{array}{l}\text { Melin et } \\
\text { al., (2006) }\end{array}$ \\
\hline MBR & \multicolumn{8}{|c|}{$\begin{array}{l}\text { Removal of some PhACs (\%): } \\
\text { Analgesics: 70; Antibiotics: } 64.7 \text {; Liquid regulator: } 74.8 \text {; B-blocker: } 57.2 \text {; } \\
\text { Antihistamines: } 43 \text {; Antidepressant: } 94 \text {; X-ray contrast media: 59; } \\
\text { Hypoglycaemic agent: } 75 \text {; Diuretics: } 22 \text {. }\end{array}$} & $\begin{array}{l}\text { MBR can efficiently } \\
\text { remove PhACs, however, } \\
\text { biological degradation } \\
\text { remains subject to many } \\
\text { uncertainties }\end{array}$ & - & $\begin{array}{l}\text { Sipma et } \\
\text { al., }(2010)\end{array}$ \\
\hline
\end{tabular}

Abbreviation: EDCs = Endocrine Disrupting Compounds; SAT $=$ Soil Aquifer Treatment; MBR = Membrane Bioreactor; DOC $=$ Dissolved Organic Carbon, PhACs $=$ Pharmaceutical Active Compounds. 
Table 9. Industrial wastewater quality improvement and reuse through selected treatment processes

\begin{tabular}{|c|c|c|c|c|c|c|c|c|c|c|}
\hline \multirow{2}{*}{$\begin{array}{l}\text { Wastewater } \\
\text { origin }\end{array}$} & \multirow{2}{*}{$\begin{array}{l}\text { Treatment } \\
\text { processes }\end{array}$} & \multicolumn{6}{|c|}{ Treated Water quality (\% removal) } & \multirow{2}{*}{ Comments } & \multirow{2}{*}{ Reuse application } & \multirow{2}{*}{ References } \\
\hline & & TSS & Turbidity & $\mathrm{BOD}_{5}$ & COD & $\mathrm{TN}$ & $\mathrm{TP}$ & & & \\
\hline $\begin{array}{l}\text { Tannery } \\
\text { industry }\end{array}$ & $\begin{array}{l}\text { CWs } \\
\text { (HRT } 7 \text { days) }\end{array}$ & 88 & - & 77 & 83 & 48 & 38 & $\begin{array}{l}\text { CWs can be subjected to higher } \\
\text { organic and hydraulic loadings } \\
\text { and fluctuations and } \\
\text { interruptions in industrial } \\
\text { scenarios }\end{array}$ & $\begin{array}{l}\text { Industrial } \\
\text { applications }\end{array}$ & $\begin{array}{l}\text { Calheiros et } \\
\text { al., (2009) }\end{array}$ \\
\hline Paper mill & MBR & 99.1 & 99 & 98 & 86 & 90 & - & $\begin{array}{l}\text { MBR could save the need for } \\
\text { further filtration, but the high } \\
\text { hardness can create scaling } \\
\text { problems }\end{array}$ & $\begin{array}{l}\text { Internal industrial } \\
\text { processes in the } \\
\text { paper mill }\end{array}$ & \\
\hline Food industry & MBR & 98.9 & 97 & 97 & 88 & 10 & - & $\begin{array}{l}\text { The accumulated edible oil } \\
\text { may cause deterioration of the } \\
\text { effluent quality. This problem } \\
\text { can be solved by pre-treatment } \\
\text { or the reduction of cell } \\
\text { residence time }\end{array}$ & $\begin{array}{l}\text { Internal industrial } \\
\text { processes such as } \\
\text { non-food and plant } \\
\text { cleaning, washing } \\
\text { or cooling } \\
\text { processes }\end{array}$ & $\begin{array}{l}\text { Galil and } \\
\text { Levinsky, } \\
(2007)\end{array}$ \\
\hline $\begin{array}{l}\text { Petrochemical } \\
\text { industry }\end{array}$ & MBR & 96.7 & 99.1 & 97 & 56 & 28.9 & - & $\begin{array}{l}\text { MBR can efficiently remove } \\
\text { organic matter and oil }\end{array}$ & $\begin{array}{l}\text { Reuse in internal } \\
\text { industrial processes } \\
\text { or discharge to sea }\end{array}$ & \\
\hline
\end{tabular}

\footnotetext{
Abbreviation: $\%=$ percentage removal; TSS $=$ Total Suspended Solids; $\mathrm{BOD}_{5}=$ Biological Oxygen Demand; COD $=$ Chemical Oxygen Demand; $\mathrm{TN}=$ Total Nitrogen; $\mathrm{TP}=$ Total Phosphorus; $\mathrm{CWs}=$ Constructed Wetlands; $\mathrm{MBR}=$ Membrane Bioreactor.
} 
With respect to municipal wastewater, both $\mathrm{UF} / \mathrm{RO}$ and MBR processes perform well in removal of microbial parameters as well as TSS, turbidity, COD, BOD, etc. (Table 8). In addition, MBR is superior over CAS in treating pharmaceutical pollutants and endocrine disrupting compounds (EDCs) which are increasingly discharged to municipal sewage. These substances have received lots of concern due to their uncertainty, toxicity and persistence (Melin et al., 2006; Sipma et al., 2010). So far, many countries including Australia, China, Singapore, the U.S., Canada, Europe and the Middle East have been using membrane technologies for various water reuse schemes, including the Rouse Hill residential water reuse scheme in Sydney, Australia, the Olympic Forest Park irrigation scheme in Beijing, China, the Groundwater Replenishment Scheme in Orange County, California, the U.S., industrial produced water reuse projects in Oman and Saudi Arabia, etc. (Chapman et al., 2001). Till now, most of these schemes are successfully operated for IPR or DPR which require high water quality, and. neither environmental nor public health problems have been detected (Asano et al., 2007; Dominguez-Chicas and Scrimshaw, 2010).

In Singapore, a two years' study consisting of 20,000 analyses on Water Reclamation Plant have demonstrated that the recycled water from NEWater Incorporation is cleaner than raw fresh water drawn from river sources and reservoir water in terms of minerals, organic substances, suspended particles and bacteriological quality (Kelly and Stevens, 2005). Similarly, in the U.S., the health effect study on San Diego's IPR scheme reported that health risk associated with the use of recycled water as a raw water supply is less than or equal to that of the use of existing raw water supply (Olivieri et al., 1996). In Africa, the wastewater used for DPR schemes in Namibia is processed by several treatment processes including dissolved air flotation, sand filtration, biological and granular activated carbon filtration, UF and chlorination. The projects have been successfully operated for about 40 years without adverse health effect (Du-Pisani, 2006; Wedick, 2007; Huertas et al., 2008). Consequently, 
after appropriate treatment, municipal wastewater can be a consistent, reliable and safe supplement to the existing water supply for a variety of end uses including non potable applications, IPR and DPR. Regarding to industrial wastewater, MBR and CWs are proved to be effective methods in hazard removal (Table 9). MBR is proved to have high performance not only in filtering degradable organics but also hydrophobic and low biodegradable compounds such as EDCs and pharmaceutical active compounds (PhACs) (Galil and Levinsky, 2007; Calheiros et al., 2009; Vymazal, 2009; Barakat, 2010). CWs can be considered as relatively low cost options but require large space for treatment. After going through sufficient barriers, the treated effluent can be reused as cooling water, boiler feed water or industrial process water in closed industrial processing systems internally. Alternatively, it might be discharged to centralized municipal treatment plants for external integrated water reuses (Mohsen and Jaber, 2002; U.S. EPA, 2004).

Apart from treatment processes listed in Tables 6-9, significant improvement in water quality (physicochemical and biological) may take place during long-term storage. Liran et al. (1994) found that long retention time in reservoir reduced coliform levels by one to two orders of magnitude. Van Breemen et al. (1998) observed significant decreases of Giardia and Cryptosporidium concentrations during water storage in Dutch reservoirs, where elimination rates of 1.7 to $3.1 \log 10$ units were found. Lazarova and Bahri (2005) also stated that coliform removal could reach 3-4 $\log 10$ units as orders of magnitude but depended greatly on hydraulic residence time and climate conditions. Overall, storing recycled water in reservoirs can improve microbiological quality and provide peak-equalization capacity, thus increase the reliability of supply and improve the rate of reuse (Qadir et al. 2010). Furthermore, groundwater recharge can also dilute, filtrate and store recycled water as well as partly prevent saltwater intrusion and mitigate subsidence (Asano and Cotruvo, 2004; Feo et al., 2007). Juhna at al. (2003) reported the effective removal of humic substances during 
artificial recharge of groundwater, which can give the water a yellowish to brownish and lead to the formation of carcinogenic by-products during disinfection. The study indicated that physical sorption is the major mechanism for hazard removal. Maeng et al. (2010) investigated organic micropollutants removal from wastewater effluent-impacted drinking water sources during artificial groundwater recharge. They pointed out that oxic conditions (affected by temperature) in aquifer have high degradation potential in micropollutants removal (e.g., phenazone, propyphenazone, formylamino-antipyrine and acetoaminoantipyrine).

\section{Critical Control Point}

Accidental treatment system failure and pathogen regrowth are likely to happen without warning. For example, biofilm growth in recycled water can be promoted owing to high levels of nutrients and organic carbon or low levels of residual disinfectant. Besides, changes in recycled water quality may occur during storage and distribution as a result of contamination by stormwater or wildlife (Higgins et al., 2002). Because of these reasons, apart from applying sufficient wastewater treatment processes, safety assurance, monitoring and verification also play important roles in risk control. Particularly, establishing safety tools such as Hazard Analysis Critical Control Point (HACCP) systems can be quite useful for water reuse schemes. The HACCP concept was originally developed and applied by the Pillsbury Company in 1960 to deliver safe foodstuffs to the NASA space program (Dewettinck et al., 2001). From then on, HACCP has been more and more adopted in food and drinking water production as well as the management systems in many developed countries (WHO, 2003). HACCP offers a preventative management and quality assurance approach rather than random monitoring of the end point. The system involves identifying critical control points towards control potential hazards and maintaining best practices 
throughout production and distribution. After comparing intensive monitoring results with corresponding criteria such as FAO, (1997) and WHO, (2003), a quick and sufficient intervention can take place to minimise the risk on consumers' health once the critical limits are not met or a hazard is no longer under control.

Specifically, when applying HACCP to guarantee safe water reuse, the focus must be placed on the control of the exposure to wastewater as well as the elimination or reduction of the hazards through quick and effective treatment (Salgot et al., 2003; Westrell et al., 2004). Table 10 lists seven HACCP principles together with a case study in the city of Hassleholm, Sweden. Based on the principles, Figure 1 identifies basic critical control points of a water treatment and reuse system concerning health/sanitation, technical and ecological aspects. The health or sanitation control pays attention to the detection of microbiological quality parameters or indicators (e.g., legionella spp, nematode, E. coli, enterococci, cryptosporidium, giardia, enterovirus and organic micro-contaminants). Comparatively, the technical control takes into account of key treatment processes and distribution systems whereas the ecological control focuses on the recycled water quality in the distribution and reuse systems. Additionally, Derry et al. (2006) pointed out that other biophysical indicators (e.g., thermotolerant coliform, BOD, DO, $\mathrm{pH}$, temperature, conductivity and suspended solids) are also commonly selected for monitoring at control points. Hence, with HACCP, the benefits such as the increase of safety in a recycled water chain, economic cost saving (by the reduction of the number of inspections), better treated wastewater quality, real time information collection can be achieved at the same time (Huertas et al., 2008). 
Table 10. Procedures used in $\mathrm{HACCP}^{\mathrm{a}}$

\begin{tabular}{|c|c|c|}
\hline Step & HACCP principles & $\mathrm{HACCP}$ in a WWTP \\
\hline 1. & $\begin{array}{l}\text { Conduct a hazard analysis (identify and list } \\
\text { the hazards and specify control measures) }\end{array}$ & $\begin{array}{l}\text { Draw out systems structures and define } \\
\text { system boundaries }\end{array}$ \\
\hline 2. & Identify the critical control points & $\begin{array}{l}\text { Compile literature data on pathogens and } \\
\text { treatment processes }\end{array}$ \\
\hline 3. & $\begin{array}{l}\text { Establish target level(s) and tolerances, } \\
\text { which must be met to ensure each CCP is } \\
\text { under control }\end{array}$ & Site visits with specific questions \\
\hline 4. & $\begin{array}{l}\text { Establish a monitoring system to ensure } \\
\text { control of the CCP }\end{array}$ & $\begin{array}{l}\text { Construct model with data from literature } \\
\text { and site specific data }\end{array}$ \\
\hline 5. & $\begin{array}{l}\text { Establish the corrective action to be taken } \\
\text { when monitoring indicates that a CCP is } \\
\text { moving out of control }\end{array}$ & $\begin{array}{l}\text { Examine exposure pathways and site } \\
\text { discussions with personnel }\end{array}$ \\
\hline 6. & Establish documentation & Rank exposures after highest risk \\
\hline 7. & Establish verification procedures & $\begin{array}{l}\text { Choose control points for each type of } \\
\text { hazardous exposure }\end{array}$ \\
\hline 8. & - & $\begin{array}{l}\text { Describe parameters governing the } \\
\text { performance of a certain control point }\end{array}$ \\
\hline
\end{tabular}

${ }^{\mathrm{a}}$ Modified from Salgot et al., (2003); Westrell et al., (2004).

${ }^{\mathrm{b}} \mathrm{HACCP}$ conducted at a wastewater treatment plant (WWTP) in Hassleholm, Sweden.

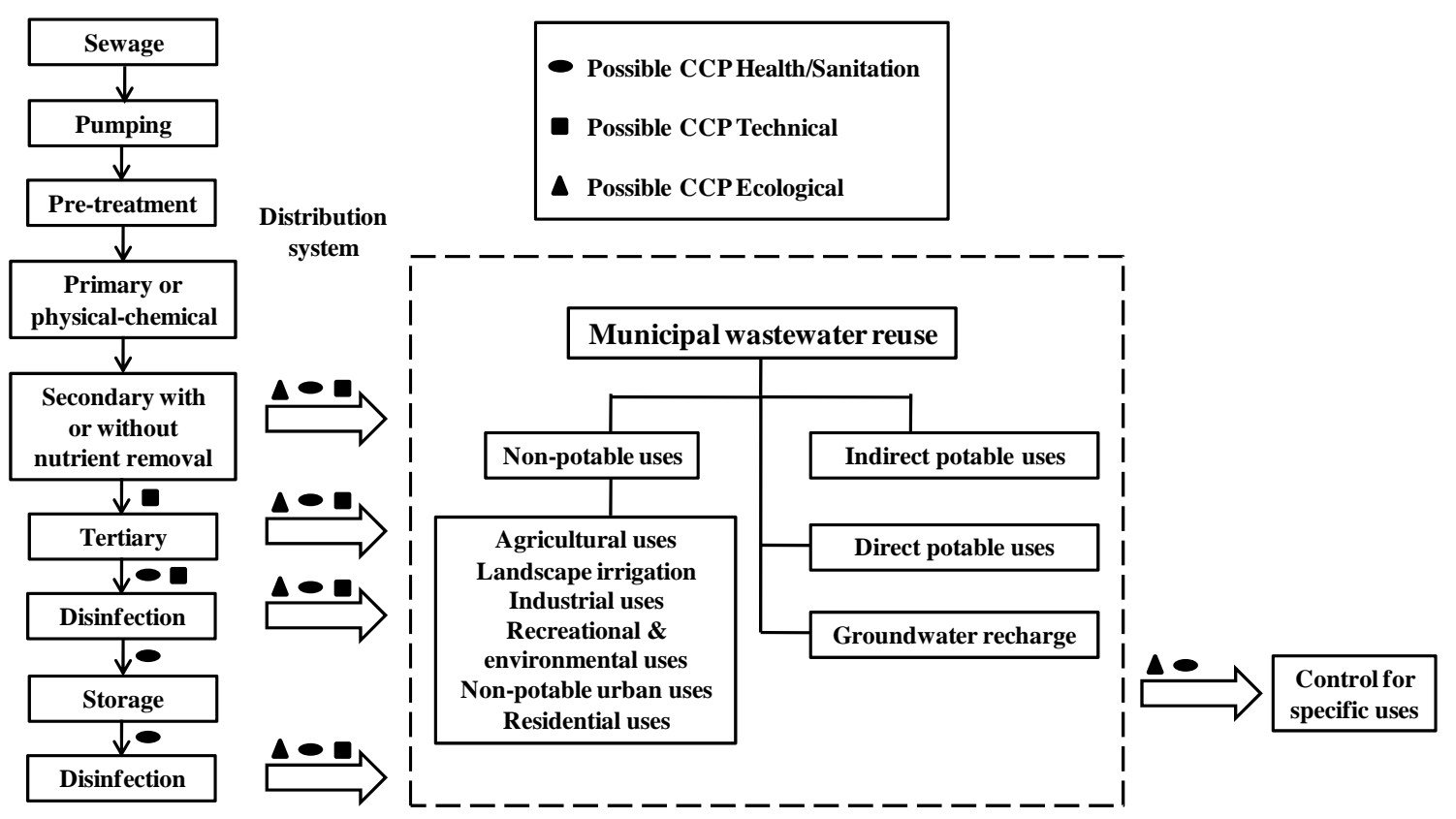

Figure 1. Possible critical control points of a water treatment system (modified from Huertas et al., 2008). 


\section{Exposure Control}

Although the technical possibility of producing high quality recycled water has been achieved, the financial insufficiency always hinders the implementation of advanced wastewater treatment and monitoring technologies in many developing countries. For example, in Pakistan, nearly $80 \%$ of crop is irrigated by raw sewage, which resulted in enteric diseases and gastrointestinal illnesses. Similar situations were observed in Vietnam, Syria, Mexico, etc. (Jimenez and Asano, 2008). In this case, exposure control is regarded as a more cost-effective way in risk minimization. To better implement the exposure control of recycled water, it is important to understand the characteristics of exposure so that exposure minimization steps can be more targeted.

\section{EXPOSURE CHARACTERISTICS}

Exposure characteristics should be well recognised because not all exposures of recycled water pose health risks to human beings. In most cases, only a sufficient number of pathogens or high concentration of chemical compounds could make adverse effect on human and the environment (Stevens et al., 2008). Hence, some key characteristics, including potential exposure pathways, exposure magnitude, medium, frequency, extent and duration in the past, at present and in the future and the exposed population, should be carefully taken into account (Khan and Roser, 2007). Table 11 summarizes several exposure characteristics related to different end uses. Generally, inhalation, ingestion and dermal contact are main exposure pathways. Taking the ingestion of meat or animal products for example, potential hazards in recycled water can expose to human via soil, plant uptake, animal uptake and food production uptake. Comparatively, for ingestion of drinking water produced from groundwater, the exposure pathway starts from recycled water to soil, vadose zone, groundwater and then human (Weber et al., 2006). The disease transmission media include 
water, soil, air and biota. Although the amount and frequency of exposure varies widely due to different age groups, living habits and work conditions, there are plenty of approaches exist for quantifying exposures. Direct methods include personal monitoring and biomonitoring, by which measurements of exposure are taken at the point of contact. The exposed population who require particular attentions include:

1. Workers have direct skin contact with recycled water or ingest aerosols in their normal working environment during irrigation, fire fighting or the recharge of recreational impoundments.

2. Consumers have direct oral contact or inhalation by eating contaminated crops or meats associated with pathogen-containing irrigation water and/or drinking purified recycled water (Campos, 2008).

3. Publics have direct skin contact with recycled water or ingest aerosols when exposing to readily accessible public areas (e.g., parks, playing fields, open public spaces, golf courses and residential gardens) or using recycled water for toilet flushing, clothes washing and showering.

4. Children fall or touch the grass and then have hand-to-mouth contact or accidentally ingest a large amount of recycled water during playing or swimming (Asano et al., 2007; Stevens et al., 2008). 
Table 11. Exposure characteristics for recycled water ${ }^{\mathrm{a}}$

\begin{tabular}{|c|c|c|c|c|c|c|}
\hline $\begin{array}{l}\text { Recycled water } \\
\text { applications }\end{array}$ & Categories & Exposed group & Route of exposure & Volume $^{\mathrm{b}}(\mathrm{mL})$ & Frequency $\left(\mathrm{yr}^{-1}\right)$ & Comments \\
\hline $\begin{array}{l}\text { Landscape irrigation- } \\
\text { unrestricted access } \\
\text { areas }\end{array}$ & $\begin{array}{l}\text { Public parks, } \\
\text { playgrounds, golf } \\
\text { courses etc }\end{array}$ & $\begin{array}{l}\text { Workers, } \\
\text { public }\end{array}$ & $\begin{array}{l}\text { Dermal adsorption, } \\
\text { inhalation, indirect } \\
\text { ingestion via contact } \\
\text { with lawns, etc }\end{array}$ & 1 & 52 & $\begin{array}{l}\text { Children and athletes are } \\
\text { likely to have higher } \\
\text { contact with recycled } \\
\text { water }\end{array}$ \\
\hline $\begin{array}{l}\text { Landscape irrigation- } \\
\text { restricted access } \\
\text { areas }\end{array}$ & $\begin{array}{l}\text { Cemeteries, green } \\
\text { belts, highway } \\
\text { medians, etc }\end{array}$ & $\begin{array}{l}\text { Workers, } \\
\text { public }\end{array}$ & $\begin{array}{l}\text { Dermal adsorption, } \\
\text { inhalation and indirect } \\
\text { ingestion, etc }\end{array}$ & $1-3$ & $17-26$ & $\begin{array}{l}\text { Most people use restricted } \\
\text { landscape areas sparingly }\end{array}$ \\
\hline \multirow{3}{*}{$\begin{array}{l}\text { Agricultural } \\
\text { irrigation }\end{array}$} & $\begin{array}{l}\text { Food crop } \\
\text { (home grown) }\end{array}$ & Consumers & Ingestion & $\begin{array}{l}5 \text { (lettuce) } \\
1 \text { (other raw } \\
\text { produce) }\end{array}$ & 50 & \multirow{2}{*}{$\begin{array}{l}\text { The exposure amount and } \\
\text { frequency depends largely } \\
\text { on personal diet habit }\end{array}$} \\
\hline & $\begin{array}{l}\text { Food crops } \\
\text { (commercial) }\end{array}$ & $\begin{array}{l}\text { Workers, } \\
\text { consumers }\end{array}$ & Ingestion & $\begin{array}{l}5 \text { (lettuce) } \\
1-3.5 \text { (other raw } \\
\text { produce) }\end{array}$ & 140 & \\
\hline & Non-food crops & Workers & $\begin{array}{l}\text { Inhalation of sprays } \\
\text { and dermal adsorption }\end{array}$ & \multicolumn{2}{|l|}{$50 \mathrm{~mL} /$ person/year } & - \\
\hline \multirow{3}{*}{ Garden irrigation } & Garden watering & Workers & $\begin{array}{l}\text { Ingestion of sprays and } \\
\text { aerosols }\end{array}$ & 0.1 & 90 & - \\
\hline & $\begin{array}{l}\text { Recreational } \\
\text { activities }\end{array}$ & consumers & $\begin{array}{l}\text { Indirect ingestion via } \\
\text { contact with plants, } \\
\text { lawns, etc }\end{array}$ & 1 & 90 & - \\
\hline & - & $\begin{array}{l}\text { Workers, } \\
\text { consumers }\end{array}$ & Accidental ingestion & 100 & 1 & Infrequent event \\
\hline
\end{tabular}

aAdapted from Westrell et al., (2004); EPHC, (2008); Khan, (2010).

${ }^{b}$ Volume: Volume ingested per person per exposure. 
Table 11. (continued) ${ }^{\mathrm{a}}$

\begin{tabular}{|c|c|c|c|c|c|c|}
\hline $\begin{array}{l}\text { Recycled water } \\
\text { applications }\end{array}$ & Categories & $\begin{array}{l}\text { Exposed } \\
\text { group }\end{array}$ & Route of exposure & Volume $^{\mathrm{b}}(\mathrm{mL})$ & Frequency $\left(\mathrm{yr}^{-1}\right)$ & Comments \\
\hline \multirow{4}{*}{$\begin{array}{l}\text { Non-potable } \\
\text { uses }\end{array}$} & Fire fighting & Fire fighters & $\begin{array}{l}\text { Ingestion of water } \\
\text { and sprays }\end{array}$ & 20 & 50 & - \\
\hline & Toilet flushing & Consumers & Ingestion of sprays & 0.01 & 1100 & $\begin{array}{l}\text { Frequency based on } \\
\text { three uses of home } \\
\text { toilet per day }\end{array}$ \\
\hline & $\begin{array}{l}\text { Washing machine } \\
\text { use }\end{array}$ & Consumers & Ingestion of sprays & 0.01 & 100 & $\begin{array}{l}\text { Frequency based on } \\
\text { every 2-3 times per } \\
\text { week }\end{array}$ \\
\hline & Showering/bathing & Consumers & $\begin{array}{l}\text { Ingestion of water } \\
\text { and sprays }\end{array}$ & $\begin{array}{l}450,000- \\
750,000\end{array}$ & 350 & $\begin{array}{l}\text { Estimation based on } \\
15-25 \text { litres/min for } 30 \\
\text { mins per shower }\end{array}$ \\
\hline $\begin{array}{l}\text { Recreational } \\
\text { uses }\end{array}$ & Swimming & Public & $\begin{array}{l}\text { Ingestion and dermal } \\
\text { contact }\end{array}$ & 50 & 10 & - \\
\hline Potable use & $\begin{array}{l}\text { Cross-connection of } \\
\text { dual reticulation } \\
\text { systems with } \\
\text { drinking water } \\
\text { mains }\end{array}$ & Consumers & Ingestion & 1000 & $\begin{array}{l}365 \text { for } 1 / 1000 \\
\text { houses }\end{array}$ & $\begin{array}{l}\text { - Individuals may } \\
\text { consume water } 365 \\
\text { days/year, however, } \\
\text { only about } 1 / 1000 \\
\text { houses is affected } \\
\text { - This is likely to be a } \\
\text { conservative } \\
\text { estimate }\end{array}$ \\
\hline
\end{tabular}

${ }^{\mathrm{a}}$ Adapted from Westrell et al., (2004); EPHC, (2008); Khan, (2010).

${ }^{\mathrm{b}}$ Volume: Contact volume per person per exposure. 
Indirect approaches such as environmental monitoring, questionnaires, diaries and exposure models involve extrapolating exposure estimates from other measurements or existing data. Currently, some exposure models (e.g., the contaminated land exposure assessment model, air dispersion models, contaminant leaching models, pollutant runoff models and environmental concentration models) have been increasingly used as important tools for indirect exposure assessments (Fryer et al., 2006). Nevertheless, due to their complexity, variability and uncertainty, exposure models are seldom applied to risk assessment in recycled water. Overall, the complexity of estimating exposure characteristics must be acknowledged based on the continuing behaviour change of customers, especially when drought conditions intensify or diminish and/or water usage restrictions are altered. Besides, the possibility of customers using recycled water for purposes other than those recommended also contributes to the complexity and uncertainty of exposure (O'Toole et al., 2008).

\section{EXPOSURE MINIMIZATION}

If recycled water is going to be used for intended purposes, any possible exposure should be minimized or prevented. Accordingly, exposure control approaches such as applying exposure restrictions (e.g., public access control, recycled water use restriction) and setting exposure barriers (e.g., signage, fencing, special taps and staff access protection) should be performed to reduce the direct contact of recycled water with human and the environment. In particular, as agricultural and landscape irrigations represent the largest recycled water consumption around the world, exposure controls on these two categories become focal point at issue. 
Irrigation Management. Choosing suitable irrigation method can be an effective way to minimise the following risks: plant toxicity due to direct contact between leaves and water, salt accumulation in the root zone, health hazards related to aerosol spraying and direct contact with irrigators and product consumers as well as water body contamination due to excessive water loss by runoff and percolation (Capra and Scicolone, 2007). According to the exposure risks of recycled water associated with irrigation systems, drip irrigation, especially with sub-surface drippers, has the lowest risk of exposure level and becomes the most popular and reliable at present (Stevens et al., 2008). It allows the water to go directly into the soil surface without contaminating plants thus minimize crop/plant and human contact (Huertas et al., 2008). It also applies less water due to higher efficiency reducing the risk of exposure to pathogens. Al-Juaidi et al. (2010) demonstrated that, given the same treatment and irrigation conditions on agricultural land areas, tertiary treated effluent drip irrigation at 25 days elapsed time between last irrigation and consumption led to the lowest annual risk of $10^{-12}$ compared with $10^{-9}$ and $10^{-8}$ annual risk for sprinkler and surface irrigation respectively. Besides, only tertiary treated effluent could effectively avoid the clogging of the drippers and filtering difficulties caused by bacteria and algae. Due to technical or economic restrictions, other traditional irrigation methods are widely applied especially in developing countries, with which some special control measures should be coupled with. For instance, when flood irrigation method is going to be used, as the water use efficiency is low, exposure controls can be achieved through protection of field workers, crop handlers and consumers. Although sprinkler irrigation method is not recommended as this spreads the water on the crop surface, it has received attractive concerns and discussions during the 1980s. To apply this method, minimum distance of 50-100 m from houses and roads as well as water quality restrictions are required. Table 12 gives detailed risk reduction achievements regarding different 
irrigation methods (Deboer and Linstedt, 1985; Lazarova and Bahri, 2005; NRMMC-EPHCAHMC, 2006; EPHC, 2008; Kamizoulis, 2008; Qadir et al., 2010).

Table 12. Restrictions and effects on crops and public access ${ }^{\mathrm{a}}$

\begin{tabular}{|c|c|c|}
\hline $\begin{array}{l}\text { Exposure minimization } \\
\text { methods }\end{array}$ & Restrictions & $\begin{array}{l}\text { Log reduction in } \\
\text { exposure to } \\
\text { pathogens }\end{array}$ \\
\hline \multirow{10}{*}{$\begin{array}{l}\text { Crop restrictions } \\
\text { together with suitable } \\
\text { irrigation methods }\end{array}$} & Cooking & $5-6 \log s$ \\
\hline & Washing vegetables & $2-3 \log s$ \\
\hline & Peeling & $2 \log$ \\
\hline & Drip irrigation of crops & $2 \log$ \\
\hline & $\begin{array}{l}\text { Drip irrigation of crops with limited to no } \\
\text { ground contact (e.g., tomatoes, capsicums) }\end{array}$ & $3 \log$ \\
\hline & $\begin{array}{l}\text { Drip irrigation of raised crops with no ground } \\
\text { contact (e.g., apples, apricots, grapes) }\end{array}$ & $5 \log$ \\
\hline & Drip irrigation of plants/shrubs & $4 \log$ \\
\hline & $\begin{array}{l}\text { Sub-surface irrigation of plants/shrubs or } \\
\text { grass }\end{array}$ & $5-6 \log s$ \\
\hline & Sub-surface irrigation of above ground crops & $4 \log$ \\
\hline & $\begin{array}{l}\text { Spray drift control (micro-sprinklers, } \\
\text { anemometer systems, inward-throwing } \\
\text { sprinklers, etc.) }\end{array}$ & $1 \log$ \\
\hline \multirow{4}{*}{$\begin{array}{l}\text { Public access } \\
\text { restriction }\end{array}$} & $\begin{array}{l}\text { Withholding periods-for lower class water } \\
\text { (1-4 h until dry) }\end{array}$ & $1 \log$ \\
\hline & No public access during irrigation & $2 \log$ \\
\hline & $\begin{array}{l}\text { No public access during irrigation and limited } \\
\text { contact following irrigation (e.g., food crop } \\
\text { irrigation rather than public open space) }\end{array}$ & $3 \log$ \\
\hline & Buffer zone $(50-100 \mathrm{~m})$ & $1 \log$ \\
\hline
\end{tabular}

${ }^{\mathrm{a}}$ Modified from Kamizoulis, (2008).

If low quality water is used for agricultural irrigation, the implementation of good cultivation practices is a feasible means to ensure worker safety, because high dust areas, hand cultivation, hand harvest of food crops, moving sprinkler equipment and direct contact with irrigation water often lead to high risks to agricultural workers. Thus, mechanized 
cultural practices, mechanized harvesting practices, crop dried prior to harvesting and long dry periods between irrigations can result in low risk of infection (Lazarova and Bahri, 2005). Furthermore, other solutions such as flushing irrigation lines/pipes with non-recycled water sources after each irrigation activity, preventing pipe works from leakage and/or installing and maintaining adequate buffers, contribute to exposure minimization as well.

Restrictions on Crops and Public Access. In general, behaviours that are likely to possess high risks to consumers, filed workers and handlers include: any crops eaten uncooked, crops grown in close contact with wastewater effluent (e.g., fresh vegetables and spray-irrigated fruits), and/or spray irrigation within $100 \mathrm{~m}$ of residential areas or public places regardless of crop type. Irrigating landscape areas with public access (parks and lawns) or golf courses manually are also considered as high levels of risk. For these reasons, adopting crop restrictions can be sound solutions for human health protection in water reuse schemes. According to Table 12, effective crop restriction methods can successfully reduce the risk concerns to negligible level. If additional conditions are available, including the strong law enforcement, effective water allocation plans, strong central management and adequate market demand, crop restriction can be implemented even more successfully (Lazarova and Bahri, 2005; Qadir et al., 2010). With respect to public assess restrictions, the likelihood of people being affected is low when irrigating at a certain time (e.g., late at night) and/or implementing an appropriate withholding period between last irrigation and consumption to allow the irrigation area to dry before access.

Human Exposure Control. The main methods of exposure minimization for the risk groups during irrigation with recycled water are as follows: 
1. Workers and crop handlers should wear waterproof and protective coats, boots, gloves and facial masks, cover all wounds during working time, be immunized against Hepatitis A and other diseases that can be transmitted through wastewater use, and wash their hands, arms and legs at the end of each working day.

2. Consumers should wash and cook agricultural products before consumption as well as maintain high standards of hygiene (e.g., wash hands with soap and clean water before eating and/or drinking).

3. Local residents, golfers and other athletes should be kept fully informed on the use of recycled water by signage and pipe labelling.

Control activities towards other end uses. With respect to end uses such as toilet flushing and clothes washing, online monitoring of recycled water quality (e.g., turbidity and chlorine residual) with alarms for non-conformance performances against critical limits should be carried out as recycled water has frequent contact with residents. Using spray controllers on toilet bowls and washing machines can provide more gentle flows and less aerosols thereby reducing aerosol contact to some extent. In addition, it is also encouraged to apply potable water and soap or alcohol-based gel to wash and clean hands and/or body at the end of each water reuse activity. Similarly, considering environmental and recreational uses, the important parameters such as the number of pathogens, the concentration of nutrients as well as colour, odour and temperature are also required to be monitored frequently to ensure the protection of public health and amenity. Hence, visually inspecting water for clarity, bluegreen algae growth and ponding during water use should be implemented regularly in case of water quality degradation. Washing hands or bodies after contact with recycled water or other people and/or wildlife is always encouraged as well (Brisbane Airport Corporation (BAC), 2010). Comparatively, when targeting recycled waters with high exposure to workers (e.g., 
industrial uses, road cleaning, fire fighting, and car washing), other sound solutions should be conducted, such as increasing droplet size if spraying water, notifying and relocating workers when recycled water is in use, training and educating workers regarding hygiene practices, protecting against direct contact with waterproof dressings and gloves and/or providing ready access to adequate hand washing amenities. Furthermore, since most IPR and DPR projects are successfully operated without detecting any environmental or public health problems due to the implementation of advanced wastewater treatment technologies (e.g., MF, UF, RO, NF, MBR and UV disinfection), exposure controls on these schemes might not be required (Asano et al., 2007; Dominguez-Chicas and Scrimshaw, 2010).

\section{RISK ASSESSMENT}

To further investigate the pathogenic or chemical risk, the construction of an assessment model becomes essential and important for any recycled water scheme. Once the potential hazards, their sources and exposure characteristics have been identified, the model is able to identify the potential adverse effects associated with each recycling activity either from a qualitative or quantitative approach (Soller, 2006). As a result, the priorities for risk management and communication can be established together with the modifications of existing recycled water quality standards or rules. The accumulated risk data can also assist in choosing more suitable and reliable treatment processes where the risk is lower and reducing the related costs (NRMMC-EPHC-AHMC, 2006; Huertas et al., 2008).

\section{Qualitative Risk Estimation}

Qualitative risk can be estimated on the basis of past records, practices, experiences, relevant literature, experiments and/or expert judgements. As numerical data or resources are inadequate under certain circumstances, the risk may be judged from individual's or group's 
degree of belief. Thus, some errors might occur inevitably. This kind of approach can only be an initial screening for risk assessment and is normally conducted by combining consequences and their likelihood of potential hazards in recycled water (Storey and Kaucner, 2009; Khan, 2010). Adverse consequences related to water reuse schemes include inadequate or variable water quality, failure of achieving the technical or financial requirements for the correct functioning of the system, acute and chronic effects to public health and the environment. On the other hand, the likelihood can be measured from historical data regarding concentrations and frequencies at the entrance of the barrier together with the variability of the concentration and the ability to mitigate the hazard. Qualitative consequences table describes the severities of these adverse effects to human health and the environment in five levels (insignificant, minor, moderate, major and catastrophic). The table of likelihood also divides the likelihood into five levels (rare, unlikely, possible, likely and almost certain) according to the expected frequency of the adverse events from once in 100 years to once a year. From these two tables, one can easily pick out the most suitable descriptors in correspondence with the actual consequence and the likelihood (DominguezChicas and Scrimshaw, 2010; Khan, 2010). Combining the descriptors from the consequences and likelihood tables, a qualitative estimation of risk can be identified using a risk matrix (Table 13). Although some scenarios are almost certain or have moderate consequences, they can generate low risks when the likelihood is balanced against consequences (Roser et al., 2006). 
Table 13. Qualitative risk matrix ${ }^{\mathrm{a}}$

\begin{tabular}{|c|c|c|c|c|c|}
\hline \multirow[b]{2}{*}{ Likelihood } & \multicolumn{5}{|c|}{ Consequences } \\
\hline & $\begin{array}{l}\text { Insignificant } \\
\text { (insignificant impact } \\
\text { or not detectable) }\end{array}$ & $\begin{array}{l}\text { Minor } \\
\text { (minor impact for } \\
\text { small population) }\end{array}$ & $\begin{array}{l}\text { Moderate } \\
\text { (minor impact for } \\
\text { large population) }\end{array}$ & $\begin{array}{l}\text { Major } \\
\text { (major impact for } \\
\text { small population) }\end{array}$ & $\begin{array}{l}\text { Catastrophic } \\
\text { (major impact for } \\
\text { large population) }\end{array}$ \\
\hline $\begin{array}{l}\text { Rare } \\
\text { (may occur once in } 100 \text { years) }\end{array}$ & Low & Low & Low & High & High \\
\hline $\begin{array}{l}\text { Unlikely } \\
\text { (could occur within } 20 \text { years) }\end{array}$ & Low & Low & Moderate & High & Very high \\
\hline $\begin{array}{l}\text { Possible } \\
\text { (might occur within } 5 \text { to } 10 \text { years ) }\end{array}$ & Low & Moderate & High & Very high & Very high \\
\hline $\begin{array}{l}\text { Likely } \\
\text { (might occur within } 1 \text { to } 5 \text { years) }\end{array}$ & Low & Moderate & High & Very high & Very high \\
\hline $\begin{array}{l}\text { Almost certain } \\
\text { (will occur once a year) }\end{array}$ & Low & Moderate & High & Very high & Very high \\
\hline
\end{tabular}

aAdapted from NRMMC-EPHC-AHMC, (2006). 
Based on Table 13, Government of Western Australia (GWA) (2009) has determined the levels of exposure risks towards expected end uses (Table 14). Derry et al. (2006) have also conducted a rapid health-risk assessment on recycled water reuse at the University of Western Sydney for agricultural and landscape irrigation. Due to lack of sufficient numerical data, the risks together with uncertainty factors were estimated roughly on a scale of 1-100 (Table 15). As can be seen from both of the tables, when recycled water has frequent contact with people or the injection volume of recycled water is high each time, the risk is likely to be high. Besides, more attention should be paid to these high-risk water reuse categories with risk control actions to the greatest extent. Concerning the microbial risks, Roser et al. (2006) investigated the MF/RO treated tertiary effluent discharging into Hawkesbury-Nepean River, at Penrith and North Richmond in New South Wales, Australia. Table 16 lists risks related to different water reuse scenarios. As Hawkesbury-Nepean River receives around 160 ML per day of treated wastewater, direct drinking of untreated river water on a continuous basis is seen as a worst case but a very unlikely one. Comparatively, scenarios associated with consumption of large volumes of water during large scale/extended duration breakdown in the MF/RO system are of great concern. The study suggested that collecting complete information on $\mathrm{MF} / \mathrm{RO}$ failure modes and developing critical limits on $\mathrm{MF} / \mathrm{RO}$ performance can be good ways to ensure the system sufficient to achieve a low risk for downstream water users. 
Table 14. Exposure risk levels ${ }^{\mathrm{a}}$

\begin{tabular}{ll}
\hline End uses & Risk level \\
\hline Residential dual pipe & \\
Internal reuse and external surface irrigation in multi-unit dwellings & High \\
Agricultural irrigation for unprocessed food crops (salad etc.) & \\
Urban surface irrigation with unrestricted access and application & \\
Commercial uses-toilet flushing and dedicated cold water taps washing & \\
machines & Moderate \\
\hline Urban surface irrigation with some restricted access and application & \\
Fountains and water features & Low \\
Industrial use with potential human exposure & \\
\hline Urban irrigation with enhanced restricted access and application & Extra low \\
Residential dual reticulation (sub-surface for fruit trees) & \\
Agricultural irrigation for non-edible crops & \\
\hline Woodlots (forestry) and sub-surface irrigation & \\
\hline Subsurface reticulation (non-food crops) &
\end{tabular}

${ }^{\mathrm{a}}$ Adapted from GWA, (2009).

Table 15. Rapid risk assessment on recycled water ${ }^{\mathrm{a}}$

\begin{tabular}{|c|c|c|c|c|}
\hline $\begin{array}{l}\text { Recycled water } \\
\text { applications }\end{array}$ & Exposed population & Exposure routine & $\begin{array}{l}\text { Risk value } \\
(1-100)^{\mathrm{b}}\end{array}$ & $\begin{array}{l}\text { Uncertainty } \\
\text { value }(1-100)^{\mathrm{c}}\end{array}$ \\
\hline \multirow{3}{*}{$\begin{array}{l}\text { Landscape } \\
\text { irrigation }\end{array}$} & $\begin{array}{l}\text { Mentally challenged or } \\
\text { immuno-compromised } \\
\text { participants }\end{array}$ & Ingestion & 49 & 60 \\
\hline & Workers & $\begin{array}{l}\text { Ingestion or } \\
\text { dermal contact }\end{array}$ & 42 & 55 \\
\hline & $\begin{array}{l}\text { Publics playing on } \\
\text { sports fields }\end{array}$ & $\begin{array}{l}\text { Ingestion of } \\
\text { aerosols }\end{array}$ & 35 & 70 \\
\hline \multirow{3}{*}{$\begin{array}{l}\text { Agricultural } \\
\text { irrigation }\end{array}$} & $\begin{array}{l}\text { Students, campus staff } \\
\text { and work-opportunity } \\
\text { participants }\end{array}$ & $\begin{array}{l}\text { Ingestion of fruit, } \\
\text { nuts and some } \\
\text { vegetables }\end{array}$ & 45 & 45 \\
\hline & Consumers & Dairy animals & 40 & 50 \\
\hline & Children & Ingestion of fruit & 40 & 60 \\
\hline
\end{tabular}

${ }^{a}$ Adapted from Derry et al., (2006).

${ }^{b}$ Risk value (1-100): 1-Lowest risk; 100-Highest risk; Higher values indicate the capacity to accommodate more serious hazards.

${ }^{c}$ Uncertainty value (1-100): 1-Lowest uncertainty; 100-Highest uncertainty; The uncertainty values exceeding 50 indicate a need for further data collection or research in many cases. 
Table 16. Qualitative microbial risk assessment for water reuse scenarios ${ }^{\mathrm{a}}$

\begin{tabular}{|c|c|c|c|c|c|c|c|}
\hline Site & $\begin{array}{l}\text { Recycled water } \\
\text { applications }\end{array}$ & Scenario & $\begin{array}{l}\text { Exposure } \\
\text { frequency }\left(\mathrm{yr}^{-1}\right)\end{array}$ & $\begin{array}{l}\text { Potential infectious } \\
\text { pathogens }\end{array}$ & Consequences & Likelihood & Risk \\
\hline \multirow{9}{*}{ Penrith } & \multirow{3}{*}{$\begin{array}{l}\text { IPR (direct drinking } \\
\text { of untreated river } \\
\text { water) }\end{array}$} & Low flow MF breakdown & 5.3 days & Campylobacter & Insignificant & Unlikely & Low \\
\hline & & Low flow RO breakdown & 5.3 days & Rotavirus & Minor & Unlikely & Low \\
\hline & & $\begin{array}{l}\text { Low flow RO+MF } \\
\text { concurrent breakdown }\end{array}$ & 5.3 days & Rotavirus & Major & Rare & High \\
\hline & \multirow{4}{*}{ Recreational reuse } & High flow & 26 days & Rotavirus & Insignificant & Likely & Low \\
\hline & & Median flow & 26 days & Rotavirus & Insignificant & Likely & Low \\
\hline & & Low flow & 26 days & Rotavirus & Insignificant & Likely & Low \\
\hline & & Low flow $\mathrm{RO}+\mathrm{MF}$ failure & 26 days & Rotavirus & Moderate & Rare & Low \\
\hline & $\begin{array}{l}\text { Direct consumption } \\
\text { of mussels }\end{array}$ & Low flow & $\begin{array}{l}26 \text { meals } \\
(1 \text { meal per day) }\end{array}$ & Campylobacter & Insignificant & $\begin{array}{l}\text { Unlikely- } \\
\text { Possible }\end{array}$ & Low \\
\hline & $\begin{array}{l}\text { Direct consumption } \\
\text { of irrigated lettuce }\end{array}$ & Low flow & 365 days & Campylobacter & Insignificant & Possible & Low \\
\hline \multirow{2}{*}{$\begin{array}{l}\text { North } \\
\text { Richmond }\end{array}$} & \multirow{2}{*}{$\begin{array}{l}\text { IPR (direct drinking } \\
\text { of untreated river } \\
\text { water) }\end{array}$} & Low flow & - & Cryptosporidium & Insignificant & $\begin{array}{l}\text { Almost } \\
\text { certain }\end{array}$ & Low \\
\hline & & High flow & - & Rotavirus & Insignificant & $\begin{array}{l}\text { Almost } \\
\text { certain }\end{array}$ & Low \\
\hline
\end{tabular}

${ }^{\mathrm{a}}$ Modified from Roser et al., (2006). 
Moreover, Dominguez-Chicas and Scrimshaw (2010) investigated the chemical risks of an IPR scheme for catchment. The treatment system consists of pre-screening, MF, RO and an advanced oxidation process (AOP) utilising UV radiation and hydrogen peroxide. Despite high removal efficiency, residual hazards or potential hazardous events at each treatment barrier presented challenges to the treatment processes or resulted in operational problems within the water supply chain. According to 223 potential hazards assessed based on their removal rates and the quality of the final treated effluent, the estimated risks were displayed in a risk heat map (Figure 2), which allow for the prioritisation of hazards in the IPR scheme to a practical level. The results showed that microbiological hazards and other three chemical groups, although small in total number, were ranked as high risk attributing to high consequences. However, the likelihood data reflecting their occurrence were still not sufficient. Thus, when monitoring throughout the supply chain, more data should be collected to revise the outcomes of the risk characterization more accurately. Nevertheless, these illustrations can only be regarded as preliminary approaches in the comprehensive assessment of risk. 


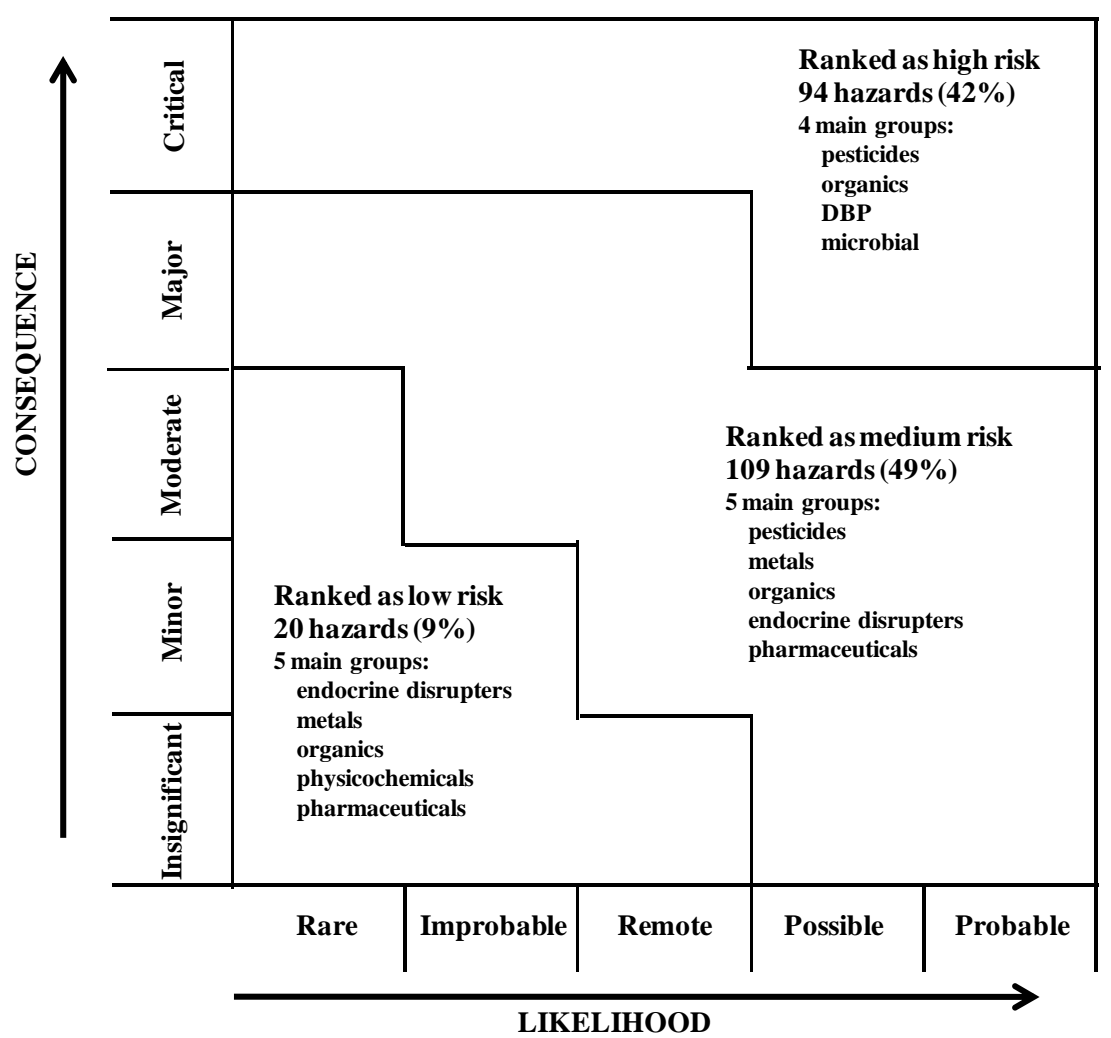

Figure 2. Risk assessment matrix of IPR schemes (adapted from Dominguez-Chicas and Scrimshaw, 2010).

\section{Quantitative Risk Estimation}

Currently, many environmental surveys and regulations have suggested the need for a quantitative approach in developing environmental guideline, standards or protection policies (Benedetti et al., 2008). The quantitative approach has been used initially to assess human health effects associated with exposure to chemicals in 1970 and can be analysed based on sufficient numerical data collected from statistical, experimental and other sources for both the likelihood and possible health consequences of exposure in particular circumstances (Hammond and Coppick, 1990; Asano and Cotruvo, 2004). Generally, quantitative assessment involves four steps: hazard identification, dose-response assessment, exposure assessment and risk characterization (Figure 3). Each step is necessary in establishing and 
managing risks associated with water reuse schemes or proposals and the output can feed into risk management and risk communication processes (Huertas et al., 2008; Khan, 2010).

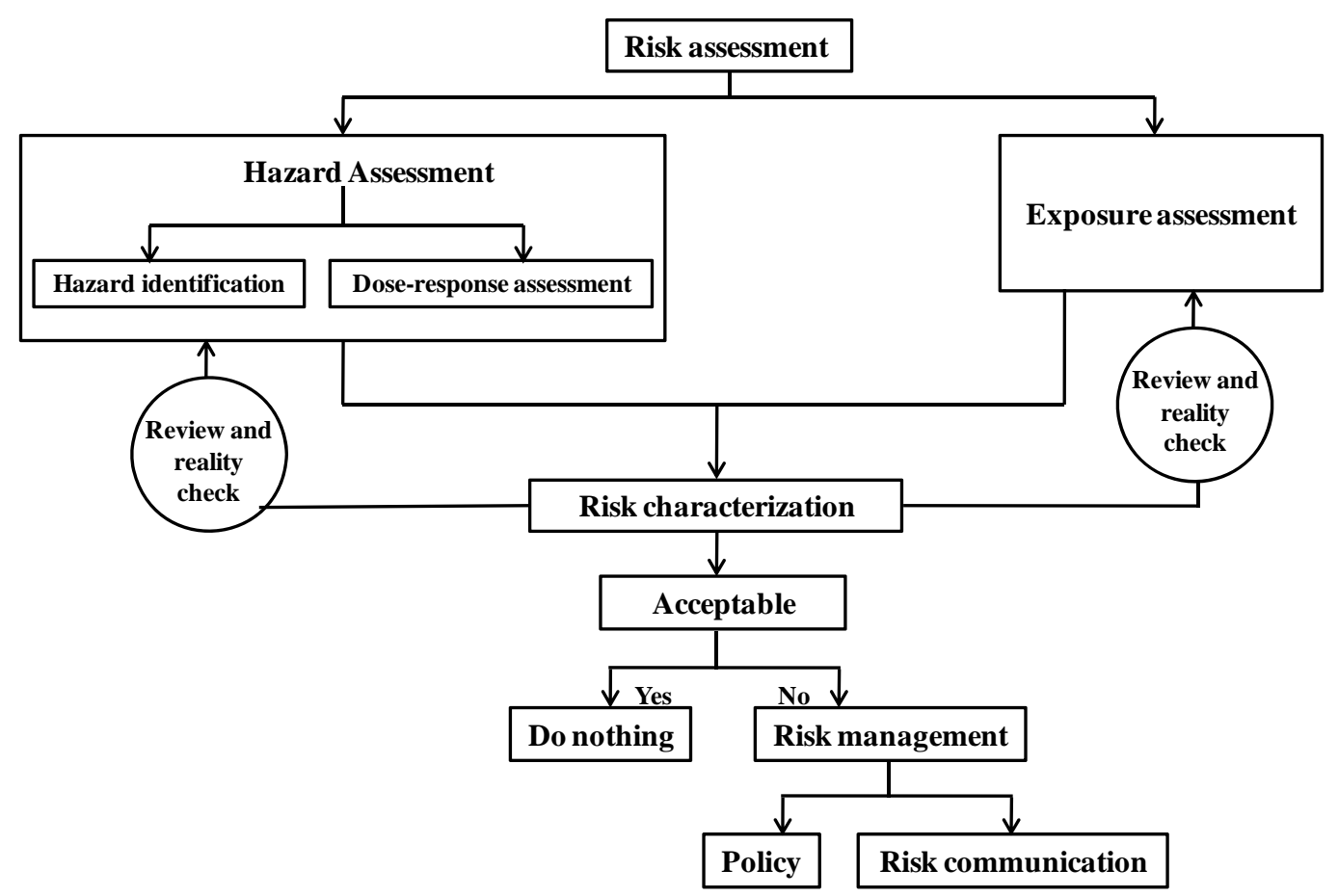

Figure 3. Quantitative risk assessment process

\section{QUANTITATIVE CHEMICAL RISK ASSESSMENT}

Current water quality guidelines for water reuse have predominately addressed risks associated with the presence of microbial organisms. Quantitative chemical risk assessments have been largely overlooked or inadequately considered. Guidelines pertaining to chemical contaminants are typically limited to bulk parameters such as COD, BOD, $\mathrm{pH}$ and TSS. Although these parameters can be good indicators for the likely presence of chemical species of concern in many situations, their sensitivity is limited for more highly treated wastewaters where an accurate assurance of specific chemical concentrations (e.g., heavy metals, mineral oils, pesticides, EDCs and PhACs) is important. Hence, to provide the most meaningful tools 
for many water reuse applications, quantitative chemical risk assessment approaches should be increasingly considered (Weber et al., 2006).

Hazard identification. Not all potential chemical hazards in wastewater have to be taken into account in hazard identification because an initial hazard screening process can be conducted by comparing hazard concentrations in recycled water with corresponding guidelines values (e.g., U.S. EPA, WHO and Australian water recycling guidelines). This process can eliminate chemicals that do not present significant (or determinant) health risks so as to minimize the unnecessary cost and allow prioritised identification of the particular hazards (NRMMC-EPHC-AHMC, 2006).

Dose-response assessment. Dose-response assessment can be quite useful for quantitative risk characterization. It normally employs a dose-response curve (Figure 4) to characterise the relationship between the exposure dose and the incidence of identified health impacts (Khan, 2010). For most toxic effects, a clear dose-response curve indicates that the probability of response increases proportionately over a certain dose change. To figure out the curve, it is indispensable to collect and analyse relevant data of human health end-points (e.g., acceptable daily intakes and acute reference doses) for the specific hazards (Roser et al., 2006). For non-carcinogenic chemicals, there are threshold doses (Curve A in Figure 4), below which no toxic effects are observed (Ritter et al., 2007). In this case, the highest dose at which no adverse effects are observed (NOAEL) or the lowset dose at which adverse effects are observed (LOAEL) can be determined from animal experiments and/or epidemiological data. Alternatively, the benchmark dose (BMD) has been proposed for deriving a more quantitative point of departure (POD) than traditional NOAEL approaches (Filipsson et al., 2003). The BMD for particular hazards can also be calculated by 
mathematical models such as Rai and Van Ryzin (RVR), national centre for toxicological research (NCTR) and log-logistic models (Faustman et al., 1996). Combining NOAEL, LOAEL or BMD with uncertainty factors, the safe risk level (RfD) can be derived as follows:

$$
\mathrm{RfD}=\frac{\text { NOAEL or LOAEL }}{\left(\mathrm{UF}_{1} \times \mathrm{UF}_{2} \ldots\right) \times \mathrm{MF}}
$$

where $\mathrm{UF}_{1}, \mathrm{UF}_{2} \ldots$ are uncertainty factors, $\mathrm{MF}$ are modifying factors. Uncertainty factors may arise from differences in the sensitivity of humans and the test animals, variability in sensitivity between humans, extrapolation of subchronic experiments to chronic exposure, the use of a LOAEL rather than a NOAEL and/or gaps in the available toxicological data. The value of each uncertain factor is assumed to be 3 or 10 with the maximum uncertainty value of 3000 (Khan, 2010). Modifying factors represent the confidence in the study which can be achieved through professional assessments (Asano et al., 2007). As RfD values are designed to protect potentially exposed populations, including sensitive sub-populations such as children and the elderly, they tend to be conservative. Some guidelines such as U.S. EPA, WHO, the California Code of Regulations-Title 22 and Australian Drinking Water Guidelines have specified RfD values as benchmarks for particular non-carcinogenic chemicals (Rodriguez et al., 2007). Beyond the RfD level, adverse response is likely to increase dramatically. On the other hand, it is assumed that there is no threshold dose for carcinogenic chemicals, so that the dose response relationships are straight lines (Curve B in Figure 4). Therefore, the carcinogenic potential of a chemical is normally expressed quantitatively as a cancer slope factor (CSF) which is the gradient of Curve B (Asano et al., 2007; Khan, 2010). 


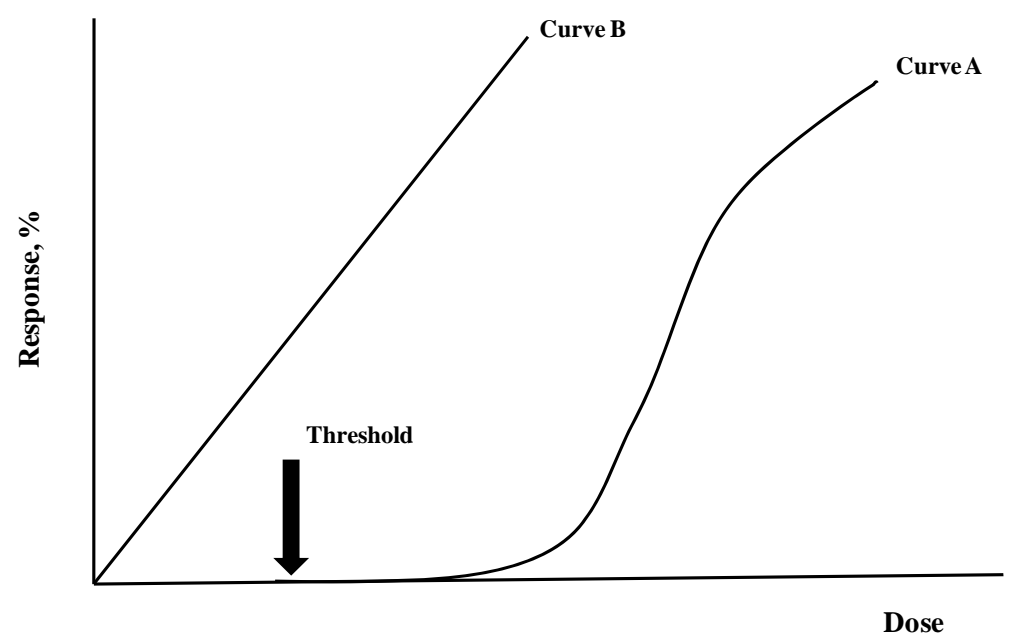

Figure 4. Dose-response curve (modified from Asano et al., 2007).

Risk characterization. By identifying the hazards, the corresponding dose-response relationships and the RfD values in a particular exposure scenario, the risk for noncarcinogenic chemicals can be measured by hazard quotient (HQ) which is the ratio of an actual exposure to the RfD (equation (2)). To demonstrate an acceptable risk to human health or the environment, exposure dose should be less than the RfD. In other words, HQ should be less than 1 (Weber et al., 2006; Khan, 2010).

Hazard Quotient $(\mathrm{HQ})=\frac{\text { Exposure dose }\left(\mathrm{mg} \cdot \mathrm{kg}^{-1} \cdot \mathrm{day}^{-1}\right)}{\operatorname{RfD}\left(\mathrm{mg} \cdot \mathrm{kg}^{-1} \cdot \mathrm{day}^{-1}\right)}$

Additionally, in some guidelines (e.g., WHO and Australian Drinking Water Guidelines), the amount and frequency of exposure (e.g., water consumption per person per day) have been added to modify equation (1) and to derive a maximum safe drinking water level. The adjusted RfD can be written as:

Safe drinking water concentration $(\mathrm{mg} / \mathrm{L})=\frac{\mathrm{POD}(\mathrm{NOAEL} \text { or LOAEL }) \times \mathrm{BW} \times \mathrm{PF}}{\mathrm{IR} \times \mathrm{UF}}$

where BW is the average body weight of an adult (commonly 70 kilograms), PF is a proportionality factor which accounts for the proportion of exposure that may be derived 
drinking water (typically 1 or 0.1 ), IR is the estimated maximum drinking water ingestion rate by an adult (2 L/day), and UF is uncertainty factor.

For carcinogenic chemicals, as there is no threshold dose, risks can be calculated as follows:

$$
\operatorname{Risk}(\mathrm{R})=\operatorname{CSF}\left(\mathrm{mg} \cdot \mathrm{kg}^{-1} \cdot \mathrm{day}^{-1}\right)^{-1} \times \operatorname{Exposure~dose}\left(\mathrm{mg} \cdot \mathrm{kg}^{-1} \cdot \mathrm{day}^{-1}\right)
$$

As such, taking into account of the exposure amount and frequency, the adjusted risk of exposing to carcinogenic chemicals can be written as:

Safe drinking water concentration $(\mathrm{mg} / \mathrm{L})=\frac{\text { Risk level } \times \mathrm{BW} \times \mathrm{PF}}{\mathrm{CSF} \times \mathrm{IR}}$

where risk level is the tolerable risk level (usually $10^{-4}, 10^{-5}$ or $10^{-6}$, specified by some international agencies), CSF is the cancer slope factor (Khan, 2010).

The above-mentioned equations have been widely applied in quantitative chemical risk assessment for recycled water. Olivieri et al. (1996) conducted a risk assessment in the city of San Diego, the U.S., for direct potable water reuse with the help of analytical detection tools. It was concluded that the estimated lifetime carcinogenic chemical risk was $3.2 \times 10^{-6}$ which was approximately 40 times less than the estimated risk related to the untreated raw water supply. The results also indicated that risk derived from non-carcinogenic chemicals was negligible. Rodriguez et al. (2007) reported a screening health risk assessment to determine whether the concentration of micropollutants after MF/RO pose any potential health risk for an IPR scheme in Perth, Western Australia. Equation (2) was used, in which the detected concentration of each chemical was compared to a benchmark value (non-effect concentration). A total of 134 analytes including volatile organic compounds (VOCs), disinfections by products (DBPs), metals, pesticides, hormones and pharmaceuticals were sampled at four locations (e.g., water reclamation plant inlet, MF permeate, RO permeate and storage dam) and then tested in laboratory. At the same time, benchmark values were 
calculated for 3 tiers chemicals. For example, the maximum contaminant level in drinking water from guidelines (e.g., U.S. EPA, WHO or Australian Drinking Water Guidelines) was used for regulated chemicals, the slope factors or risk specific doses for unregulated toxic chemicals and the threshold of toxicological concern concept for unregulated non-toxic chemicals. The results exhibited that the HQ of final effluent was 10 to 100,000 times below 1 for all VOCs and all pharmaceuticals, except cyclophosphamide $(\mathrm{HQ}=0.5)$, while the metals with higher HQ values were arsenic, beryllium, cobalt, lithium and mercury. As all values were well below 1, no increased risk would be posed by recycled water from water reclamation plant. Nevertheless, the study suggested that additional treatment barriers after RO (e.g., UV light and/or hydrogen peroxide, dilution and retention in the aquifer) can further contribute to a safe drinking water supply. Moreover, Page et al., (2008) have investigated the risks of three chemicals- diuron, simazine and chlorpyrifos in recycled water for groundwater recharge and IPR schemes. This study used analytical tools for detecting the initial concentration of the chemicals in stormwater and also took the chemical degradation fates into account, where residence time in wetlands and the aquifer, aerobic and anerobic half life were incorporated in the @ Risk Industrial v4.5 software. For each hazard, 10,000 Monte Carlo simulations were performed so that the risk outcomes were statistical distributions and represented the inherent variability as well as uncertainties in each degradation process. Since the initial assumptions used in the risk assessment were extremely conservative, all the predicted concentrations were greater than the guideline values, which indicated that all chemicals posed significant risks. Consequently, it was concluded that the aquifer could not be an effective and reliable barrier and further research would be needed to validate the treatment capacity.

Instead of using instrumental method which is regarded as an expensive approach to measure the concentration of chemicals, other studies have used the level III fugacity model 
(equations (6) and (7)) to predict their transmission fates (e.g. steady-state, non-equilibrium concentrations and distributions) from entering into the environment to running out of the WWTP.

Concentration $(\mathrm{C})=\mathrm{Z} \times \mathrm{f}$

where $\mathrm{Z}$ is the fugacity capacity which depends on the temperature, the properties of chemicals and the nature of the environment into which the chemical is dispersed. $f$ is the fugacity which means the escaping or fleeing tendency of molecules. In level III fugacity model, $\mathrm{f}$ can be calculated as follows:

$\mathrm{f}_{\mathrm{i}} \sum \mathrm{D}_{\mathrm{i}}=\mathrm{E}_{\mathrm{i}}+\sum \mathrm{D}_{\mathrm{ji}} \mathrm{f}_{\mathrm{i}}$

where $\mathrm{E}$ is the chemical discharging rate, $\mathrm{D}$ is analogous to the first order rate constant, representing individual process removing the chemical, such as chemical reactions, advective transport, and diffusive exchange between phases. The left part of equation (7) is the rate of transport and transformation that removes chemical from each compartment, and the right is emissions and transfers from other compartments (Cao et al., 2010). For example, Weber et al. (2006) have evaluated chemical risks of three selected contaminants (chloroform, 1,1,2trichloroethane and pyrene) in recycled water reused for irrigation. Incorporated with other important parameters (e.g., recycling parameters, half-life values and plant operating parameters), this model was used to determine the predicted environmental concentrations (PECs). On the other hand, predicted no effect concentrations (PNECs) were determined from acceptable daily intake (ADI) or RfD values published in U.S. EPA Integrated Risk Information System. Risk or hazard quotient then can be calculated by the ratio of PEC to PNEC. The HQs were $10^{-7}, 10^{-6}$ and $10^{-7}$ for chloroform, 1,1,2-trichloroethane and pyrene respectively, compared with $10^{-4}$ from the U.S. EPA guideline. Hence, all three chemicals in recycled water could be acceptable for human health. 
Similarly, Cao et al. (2010) conducted a probabilistic health risk assessment using this fugacity based model to simulate the distribution of three EDCs (estrone, 17 $\beta$-estradiol and 17a-ethynylestradiol) in recycled water used for an IPR scheme in Southeast Queensland, Australia. This study not only took human as research object but also included fish as comparison. The degradation fate of chemicals in recycled water treated by screening, $\mathrm{MF} / \mathrm{RO}$ or $\mathrm{UF} / \mathrm{RO}$, advanced oxidation $\left(\mathrm{UV} / \mathrm{H}_{2} \mathrm{O}_{2}\right)$ and chlorination were carefully modelled. Concerning the PNECs, the level of plasma vitellogenin was employed as a biomarker of indicated adverse effects for fish, whereas regulation values reported in the Queensland Public Health Regulation were used as benchmarks for humans. The study showed that the majority of EDCs were removed by degradation and the highest HQ was found in $17 \alpha-$ ethynylestradiol with $4 \times 10^{-3}$ for fish and $2 \times 10^{-4}$ for humans. It also demonstrated that all the simulated concentrations were below fish exposure threshold values and human public health standards. Thus, health risks to human are negligible. As can be seen from both studies, fugacity models can be regarded as an effective approach in QRA because expensive and time-consuming instrumental detection methods are avoided. Particularly, they are able to trace the chemical degradation fate via wastewater treatment processes, so that it is easy to figure out the removal efficiency of each process. Nonetheless, insufficient data and the unavailability for the selection of appropriate ADI or RfD values hinder the determination of PNECs, thereby causing high degree of uncertainty in the chemical degradation models.

\section{QUANTITATIVE MICROBIAL RISK ASSESSMENT}

Quantitative microbial risk assessment (QMRA) to characterize human health risks associated with exposure to pathogenic microorganisms was first published in the 1970s and has been gaining favour since the 1980s (Haas, 2002; Hamilton et al., 2006; Soller and Eisenberg, 2008). Currently, QMRA is commonly advocated for assessing microbial risks in 
recycled water systems (Toze et al., 2010). It is a powerful tool for estimating order-ofmagnitude risks within a community following exposure to pathogens associated with specific scenarios (Mena et al., 2008). Besides, QMRA knowledge can be used to interpret risk data, justify further staged analysis of specific hazardous events, develop rational objective remediation plans and drive their implementation (Ashbolt et al., 2010). In QMRA, processes such as hazard identification and exposure assessment are quite similar to those in quantitative chemical risk assessment.

Dose-response relations. Based on historical studies (e.g., clinical experiments, epidemiological investigations and surveillance, animal studies, and/or toxicity assays on mammalian or bacterial cells), dose response relationships for specific species can be established and used to quantify the probability of infection (Soller, 2006). In general, sigmoidal equations were found to be the best tool to describe the relationship between the pathogen doses with the likelihood of infection (Fane et al., 2002). Among the sigmoidal equations, the exponential and beta-Poisson models are the most common equations. Particularly, the dose-response relation for many protozoans and viruses tend to follow the exponential model (equation (8)), while beta-Poisson model (equation (9)) is more suitable for many bacteria and some viruses (Mcbride et al., 2002).

$$
\begin{aligned}
& \mathrm{P}_{\mathrm{i}}=1-\exp (-\mathrm{rd}) \\
& \mathrm{P}_{\mathrm{i}}=1-\left(1+\frac{\mathrm{d}}{\beta}\right)^{-\alpha}
\end{aligned}
$$

where $P_{i}$ is the daily probability of infection, $d$ refers to the mean ingested dose, $r, \alpha, \beta$ are empirical parameters which are assumed to be constant for any given host and given pathogen. Table 17 gives particular values for these parameters with respect to some enteric pathogens. Annual probability of risk can be calculated as: 
$\mathrm{P}_{\mathrm{a}}=1-\left(1-\mathrm{P}_{\mathrm{i}}\right)^{\mathrm{n}}$

where $\mathrm{n}$ is the number of days. It is worth to note that only some amount of infected person developed clinical disease. Therefore, the risk of becoming diseased or ill can be written as:

$\mathrm{P}_{\mathrm{D}}=\mathrm{P}_{\mathrm{D}: \mathrm{i}} \times \mathrm{P}_{\mathrm{i}}$

where $\mathrm{P}_{\mathrm{D}: \mathrm{i}}$ is the probability of an infected person developing clinical disease. Additionally, other empirical models (e.g., Weibull-Gamma, Log-logistic and Log-profit models) can be used for specific pathogens under particular conditions (Haas et al., 1999). For example, Holcomb et al. (1999) reported that the Weibull-Gamma model (equation (12)) is capable of fitting the dose-response data for pathogens such as shigella, campylobacter and salmonella in some cases.

$P_{i}(d)=1-\exp \left(-q_{1} d^{q_{2}}\right)$

where $P_{i}(d)$ is the probability of infection, $d$ refers to the ingested dose, $q_{1}$ and $q_{2}$ are empirical parameters. 
Table 17. Dose-response models from various enteric pathogen ingestion studies ${ }^{\mathrm{a}}$

\begin{tabular}{llll}
\hline Model & Exponential & Beta-Poisson & \\
\hline Constituent & $\mathrm{r}$ & $\alpha$ & $\beta$ \\
\hline Virus & & \multicolumn{2}{l}{-} \\
Adenovirus & 0.4172 & - & 186.69 \\
Echovirus 12 & - & 0.374 & 0.055 \\
Norovirus & - & 0.04 & 0.4265 \\
Rotavirus & - & 0.253 & 1524 \\
Poliovirus 1 & 0.009102 & 0.1097 & 0.788 \\
Poliovirus 3 & - & 0.409 & 2360 \\
\hline Bacteria & & & 2000 \\
Salmonella & 0.00752 & 0.3126 & $1.61 \times 10^{6}$ \\
Shigella & - & 0.2 & 45.9 \\
E.coli & - & 0.1705 & 7.589 \\
E.coli O157:H7 & - & 0.4 & 13,020 \\
Campylobacter & - & 0.145 & - \\
Vibrio cholerae & - & 0.097 & - \\
\hline Protozoa & & & \\
Cryptosporidium & 0.09 & - & \\
Giardia & 0.02 & - & \\
\hline Modified from Asano et al., (2007); Soller et al., (2010a). &
\end{tabular}

As above-mentioned equations are only suitable for acute effects in most cases, Disability Adjusted Life Years (DALYs) is an alternative way to quantify the probability of infection which accounts for not only acute health effects but also for delayed and chronic effects including morbidity and mortality. It attempts to measure the health of a population in regard to the time lost because of disability or death from a specific disease or risk factor, which becomes an important tool for comparing health outcomes. When risk is described in DALYs, different health outcomes can be compared and risk management decisions can be prioritized (Campos, 2008). The following disease burden model is commonly used for the estimation of DALYs:

$\frac{\text { DALYs }}{\text { year }}=\mathrm{P}_{\mathrm{ill} / \mathrm{y}} \times \mathrm{DALYs}_{\text {per case }} \times \mathrm{S}_{\text {fraction }}$ 
where $\mathrm{P}_{\mathrm{ill} / \mathrm{y}}$ is the annual probability of illness resulting from infection. $\mathrm{P}_{\mathrm{ill} / \mathrm{y}}=\mathrm{P}_{\text {ann inf }} \times(\mathrm{ill}: \mathrm{inf})$, where ill:inf is the ratio of illness to infection for the specific pathogen. DALY $s_{\text {per case }}$ is a function of years of life lost due to the disease and years lived with a disability and $\mathrm{S}_{\text {fraction }}$ is the proportion of the population susceptible to developing the disease following infection. The values of ill:inf, DALY $\mathrm{s}_{\text {per case }}$ and $\mathrm{S}_{\text {fraction }}$ for specific pathogens can be determined from epidemiological studies (Hamilton et al., 2007). In addition, new predictive Bayesian methods for dose-response assessment have been proposed in some studies (Englehardt, 2004; Englehardt and Swartout, 2004; Cook et al., 2008). The predictive Bayesian dose-response models were applied for rotavirus infection in terms of beta-Poisson likelihood function and cryptosporidium parvum infection endpoint. These studies concluded that the Bayesian models are capable of handling limited subjective and numeric information, prioritizing expenditures for environmental protection and terrorist threats as well as assessing health effects of new and existing chemicals and pathogens. Besides, they have other strengths such as less data requirement, more flexibility and higher data incorporation than empirical models.

Risk assessment models. The most generic QMRA models for risk assessment are static microbial risk assessment (MRA) models and dynamic MRA models. Static models have been used by U.S. EPA for the development of drinking water regulations. They assume that the number of individuals which are susceptible to infection is not time varying and normally focus on estimating the probability of infection to an individual as a result of a single exposure event, thus risk is characterized at an individual level. It is also assumed that the population may be categorized into two epidemiological states: a susceptible state and an infected or diseased state. The susceptible individuals are exposed to the pathogen of interest from the specific pathway under consideration and move into the infected or diseased state 
with a probability that is governed by the dose and infectivity of pathogen (Soller, 2006). Case studies using static MRA models on recycled water reuse applications have been reported widely. Tanaka et al. (1998) carried out a health risk assessment for enteric viruses at four WWTPs, using beta-distributed probability model. The risk was expressed by reliability which was calculated as the percent of time when the infection risk was less than the acceptable risk (use $10^{-4}$ as benchmark). The risk results associated with four different reuse applications demonstrated that all secondary recycled waters can be safely used under all exposure scenarios with the reliability of essentially $100 \%$ if the inactivation/removal efficiency in tertiary treatment was increased to 5 logs. However, when secondary effluents were only treated by chlorination or contact filtration, the reliabilities regarding the recreational impoundment scenario varied greatly, which even dropped to $10 \%$ at two WWTPs. Thus, further treatments and/or risk control techniques should be coupled with.

Westrell et al. (2004) investigated the risks of several important pathogen indicators (e.g., E.coli, salmonella, giardia, cryptosporidium, rotavirus and adenovirus) in 8 recycled water exposure scenarios using @Risk software. The dose of pathogens for each exposure was estimated from the concentrations in raw sewage and WWTP based on literature data and previous study at the plant. The corresponding dose-response models and related parameters in Table 17 as well as the Monte Carlo technique with 10,000 simulations were adopted in the software for risk characterization. Table 18 summarizes the estimated risks of each pathogen associated with 4 important scenarios. The highest individual risk per single exposure was achieved through exposure to droplets and aerosols for workers at the treatment plant whereas the lowest risk arose from swimming in the lake. Regarding pathogens, viruses gave the highest risk due to high influent concentrations, low infectious doses and high resistances. This study indicated that the @Risk software is able to assess different types of pathogens associated with different water reuse scenarios in a relatively short time but it does 
not consider the secondary transmission. Besides, this study did not discuss the worst case scenarios such as flooding, a major failure in the wastewater treatment or sudden peaks based on treatment variability. These scenarios are fairly important especially for comprehensive analyses in large-scale water reuse schemes so that they need to be further evaluated.

Table 18. Median number of yearly infections resulting from different exposure scenarios ${ }^{\mathrm{a}}$

\begin{tabular}{|c|c|c|c|c|c|c|c|c|c|}
\hline $\begin{array}{l}\text { Exposure } \\
\text { scenario }\end{array}$ & $\begin{array}{l}\text { Vol. } \\
(\mathrm{mL})\end{array}$ & $\begin{array}{l}\text { Freq. } \\
\text { (times } \\
\text { per year) }\end{array}$ & $\begin{array}{l}\text { No. of } \\
\text { people } \\
\text { affected }\end{array}$ & E.coli & Sal. $^{\mathrm{d}}$ & Giardia & $\mathrm{Cp} .^{\mathrm{e}}$ & $R V .{ }^{f}$ & $\mathrm{Ad}^{\mathrm{g}}$ \\
\hline $\begin{array}{l}\text { WWTP worker } \\
\text { at pre-aeration }\end{array}$ & 1 & 52 & 2 & 0.06 & 0.004 & 0.14 & 0.02 & 1.98 & 1.99 \\
\hline $\begin{array}{l}\text { Child playing } \\
\text { at wetland } \\
\text { inlet }\end{array}$ & 1 & 2 & 30 & $0^{\mathrm{h}}$ & 0 & 0.0006 & 0 & 0.13 & 0.23 \\
\hline $\begin{array}{l}\text { Recreational } \\
\text { swimming }\end{array}$ & 50 & 10 & 300 & 0 & 0 & 0.0005 & 0.0001 & 0.04 & 0.18 \\
\hline $\begin{array}{l}\text { Consumption } \\
\text { of raw } \\
\text { vegetables }\end{array}$ & 1 & 2 & 500 & 0.002 & 0 & 0.002 & 0.01 & 0.21 & 0.41 \\
\hline
\end{tabular}

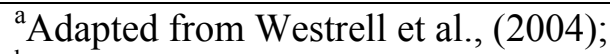

${ }^{\mathrm{b}}$ Vol.: Volume ingested per person per exposure; ${ }^{\mathrm{c}}$ Freq.: Frequency;

${ }^{\mathrm{d}}$ Sal.: Salmonella; ${ }^{\mathrm{e}} \mathrm{Cp}$.: Cryptosporidium; ${ }^{\mathrm{R} V} \mathrm{~V}$ : Rotavirus; ${ }^{\mathrm{g}} \mathrm{Ad}$.: Adenovirus

${ }^{\mathrm{h}} 0$ is equivalent to $<0.0001$ infections.

Additionally, other similar static MRA studies are summarised in Table 19 in terms of objectives, model assumptions, characteristics and risk assessment results. Compared with studies by Tanaka et al. (1998) and Westrell et al. (2004), some improvements have been made in these studies. For instance, some studies also took the pathogen decay rates into account while others combined the Monte Carlo technique and local hydrological data in the model to better represent the reality. Nevertheless, the absence of sufficient data was still the biggest barrier as lots of assumptions were underpinned in the MRA models. For studies considered pathogen decay, assumptions such as the constant decay rates were made 
regardless of other dynamic die-off reasons (e.g., desiccation, sunlight or predation) due to the unavailability of data and other technical restrictions. Besides, the above-mentioned static models can provide satisfactory risk estimates when the risks associated with direct exposure to potential hazards are low. However, when the direct risks increase to a high level, the effects of secondary transmission and immunity also increase, which justify the need for a more complex model (Soller and Eisenberg, 2008). Consequently, future work involves collecting more pertinent data, improving current modelling structure and incorporating other information in the model. 
Table 19. Static MRA models for different end uses

\begin{tabular}{|c|c|c|c|c|c|}
\hline $\begin{array}{l}\text { Water reuse } \\
\text { applications }\end{array}$ & $\begin{array}{l}\text { Pathogen of } \\
\text { interest } \\
\text { (dose-response } \\
\text { model) }\end{array}$ & Assumptions & Risk assessment result & Characteristics of model & References \\
\hline Agriculture & $\begin{array}{l}\text { Virus-Hepatitis A } \\
\text { and cholera } \\
\text { (beta-Poisson) }\end{array}$ & $\begin{array}{l}\text { The estimation is under the } \\
\text { worst case conditions } \\
\text { (any pathogens contained } \\
\text { in recycled water } \\
\text { remaining on the irrigated } \\
\text { vegetables would be } \\
\text { counted) }\end{array}$ & $\begin{array}{l}\text { - The risk from consuming cucumbers } \\
=10^{-7} \text { to } 10^{-8} / \text { year } \\
\text { - The risk from consuming lettuce }= \\
10^{-6} \text { to } 10^{-8} / \text { year }\end{array}$ & $\begin{array}{l}\text { - The laboratory instruments } \\
\text { determined the pathogen } \\
\text { doses on vegetables which } \\
\text { was then compared with } \\
\text { WHO and US EPA } \\
\text { guidelines } \\
\text { - The assumptions on dose of } \\
\text { pathogens do not consider } \\
\text { the actual filed conditions } \\
\text { - A preliminary model }\end{array}$ & $\begin{array}{l}\text { Shuval et al., } \\
\text { (1997) }\end{array}$ \\
\hline
\end{tabular}

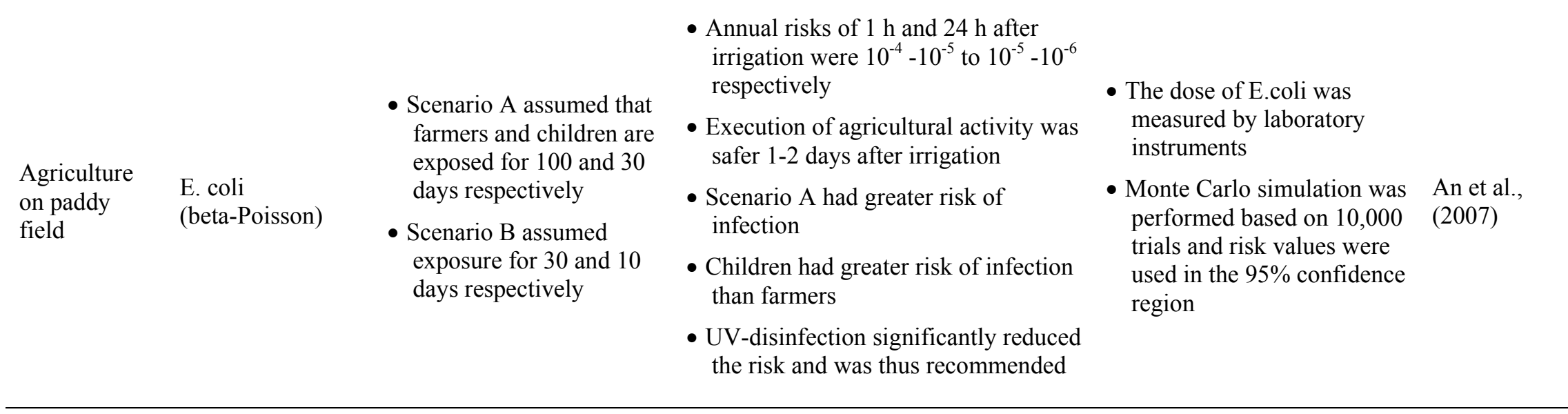


Table 19. (continued)

\begin{tabular}{|c|c|c|c|c|c|}
\hline $\begin{array}{l}\text { Water reuse } \\
\text { applications }\end{array}$ & $\begin{array}{l}\text { Pathogen of interest } \\
\text { (dose-response } \\
\text { model) }\end{array}$ & Assumptions & Risk assessment result & Characteristics of model & References \\
\hline $\begin{array}{l}\text { Landscape } \\
\text { irrigation of } \\
\text { parks and } \\
\text { golf courses }\end{array}$ & $\begin{array}{l}\text { Cryptosporidium } \\
\text { (exponential) }\end{array}$ & $\begin{array}{l}\text { - The concentration of } \\
\text { cryptosporidium was the } \\
\text { arithmetic mean of six } \\
\text { samples } \\
\text { - All infections result in } \\
\text { illness } \\
\text { - No provision for the } \\
\text { potential die-off of } \\
\text { cryptosporidium by } \\
\text { desiccation, sunlight, } \\
\text { predation or other reasons }\end{array}$ & $\begin{array}{l}\text { The risk of } 1 \mathrm{ml} \text { exposure to } \\
\text { tertiary treated recycled water }= \\
2.34 \times 10^{-7}<\text { U.S. EPA's } \\
\text { acceptable risk benchmark }\left(10^{-4}\right)\end{array}$ & $\begin{array}{l}\text { - Samples was tested by laboratory } \\
\text { instruments } \\
\text { - The database of cryptosporidium in } \\
\text { recycled water is limited, more data is } \\
\text { needed } \\
\text { - The results tended to be conservative as } \\
\text { no degradation of the pathogen was } \\
\text { applied }\end{array}$ & $\begin{array}{l}\text { Jolis et al., } \\
\text { (1999) }\end{array}$ \\
\hline $\begin{array}{l}\text { Green space } \\
\text { irrigation }\end{array}$ & $\begin{array}{l}\text { - Rotavirus and } \\
\text { Campylobacter } \\
\text { (beta-Poisson) } \\
\text { - Cryptosporidium } \\
\text { (exponential) }\end{array}$ & $\begin{array}{l}\text { - Pathogen contained in } \\
\text { secondary treated effluent } \\
\text { were infiltrated at a } \\
\text { steady rate } \\
\text { - Any pathogens in the } \\
\text { recharged aquifer are } \\
\text { pathogenic to humans, no } \\
\text { infiltration or adsorption } \\
\text { during passage through } \\
\text { the aquifer, only decay } \\
\text { - No mixing of the recycled } \\
\text { water with native } \\
\text { groundwater }\end{array}$ & $\begin{array}{l}\text { - The mean residual risk to } \\
\text { human health was the highest } \\
\text { for rotavirus followed by } \\
\text { Cryptosporidium and lowest } \\
\text { for Campylobacter with the } \\
\text { range of } 10^{-5} \text { to } 10^{-8} \text {. } \\
\text { - To obtain a mean risk below } \\
\text { the WHO guideline value } \\
\text { ( }<10^{-6} \text { DALY) for each } \\
\text { scenario including ingestion } \\
\text { of sprays, routine ingestion } \\
\text { and accidental ingestion, the } \\
\text { residence time in the aquifer } \\
\text { would need to be } 150 \text { days }\end{array}$ & $\begin{array}{l}\text { - The model incorporated pathogen decay } \\
\text { data and hydrological data as well as } \\
\text { other uncertainty and variability factors } \\
\text { to represent the reality of the aquifer } \\
\text { - The pathogen numbers derived from the } \\
\text { literature were conservative, which } \\
\text { may contribute to an overestimate of } \\
\text { risk. } \\
\text { - Pathogen decay rate was determined } \\
\text { from the slope of regression line fitted } \\
\text { by pathogen numbers over time, } \\
\text { however, more information are needed } \\
\text { - Parameters regarding filtration and } \\
\text { adsorption are difficult to measure and } \\
\text { tend to be very site specific }\end{array}$ & $\begin{array}{l}\text { Toze et al., } \\
(2010)\end{array}$ \\
\hline
\end{tabular}


Table 19. (continued)

\begin{tabular}{|c|c|c|c|c|c|}
\hline $\begin{array}{l}\text { Water reuse } \\
\text { applications }\end{array}$ & $\begin{array}{l}\text { Pathogen of } \\
\text { interest } \\
\text { (dose-response } \\
\text { model) }\end{array}$ & Assumptions & Risk assessment result & Characteristics of model & References \\
\hline $\begin{array}{l}\text { Landscape } \\
\text { irrigation and } \\
\text { residential } \\
\text { non-potable } \\
\text { reuse }\end{array}$ & $\begin{array}{l}\text { Rotavirus and } \\
\text { Giardia } \\
\text { (beta-Poisson) }\end{array}$ & $\begin{array}{l}\text { - Pathogens were shed at fixed rate to } \\
\text { sewage from infected individuals where } \\
200 \text { grams of faeces per person per day } \\
\text { was produced and wastewater } \\
\text { generation was } 145 \text { litres/capita/day } \\
\text { - The irrigation scenario assumed } 4.5 \text { and } \\
2.5 \text { log removal for enteric viruses and } \\
\text { protozoa respectively in WWTP } \\
\text { - The residential use scenario assumed } 6 \\
\text { and } 4 \text { log removal for enteric viruses } \\
\text { and protozoa respectively in WWTP } \\
\text { - Exposure of recycled water was } \\
1 \mathrm{~mL} / \mathrm{capita} / \text { year for irrigation and } 19.4 \\
\mathrm{~mL} / \mathrm{capita} / \text { year for residential reuse }\end{array}$ & $\begin{array}{l}\text { - Giardia is less infective than } \\
\text { Rotavirus and the probability } \\
\text { of infection is higher in land } \\
\text { scape irrigation scenario } \\
\text { - The probability of infection } \\
\text { increases with the increase of } \\
\text { size of population served by } \\
\text { reuse system } \\
\text { - Risk for many small exposures } \\
\text { in the form of multiple } \\
\text { aerosols ingested is higher } \\
\text { than that from a single large } \\
\text { volume of exposure }\end{array}$ & $\begin{array}{l}\text { - The model assumes no } \\
\text { thresholds } \\
\text { - Some issues that could } \\
\text { affect a general acceptance } \\
\text { were not taken into } \\
\text { account, including the } \\
\text { difference in wastewater } \\
\text { residence time between } \\
\text { systems of differing size } \\
\text { and the potential for } \\
\text { "feedback" of pathogens } \\
\text { from individuals infected } \\
\text { due to effluent reuse back } \\
\text { into sewage }\end{array}$ & $\begin{array}{l}\text { Fane et al., } \\
(2002)\end{array}$ \\
\hline $\begin{array}{l}\text { Greywater } \\
\text { reuse for toilet } \\
\text { flushing in } \\
\text { schools }\end{array}$ & $\begin{array}{l}\text { Thermo- } \\
\text { tolerant } \\
\text { coliforms } \\
\text { (TTC) } \\
\text { (beta- } \\
\text { Binomial) }\end{array}$ & $\begin{array}{l}\text { Regarding the exposure assessment, the } \\
\text { volume of greywater ingested and the } \\
\text { number of children involved or affected } \\
\text { varied in } 7 \text { schools }\end{array}$ & $\begin{array}{l}\text { - Except for } 2 \text { schools, results } \\
\text { from other five greywater } \\
\text { treatment systems indicated } \\
\text { low levels of risk } \\
\text { - DALY results }<\text { WHO } \\
\text { guideline value }\left(10^{-6}\right) \\
\text { - TTC can be a useful surrogate } \\
\text { microbial indicator for } \\
\text { greywater analysis in } \\
\text { developing countries with } \\
\text { limited analytical facilities }\end{array}$ & $\begin{array}{l}\text { - TTC were carefully } \\
\text { sampled and the number } \\
\text { of them were tested in the } \\
\text { laboratory } \\
\text { - Risks may be over- } \\
\text { estimated since children } \\
\text { were encouraged to } \\
\text { involve in the exposure } \\
\text { assessment }\end{array}$ & $\begin{array}{l}\text { Godfrey et } \\
\text { al., (2010) }\end{array}$ \\
\hline
\end{tabular}


Table 19. (continued)

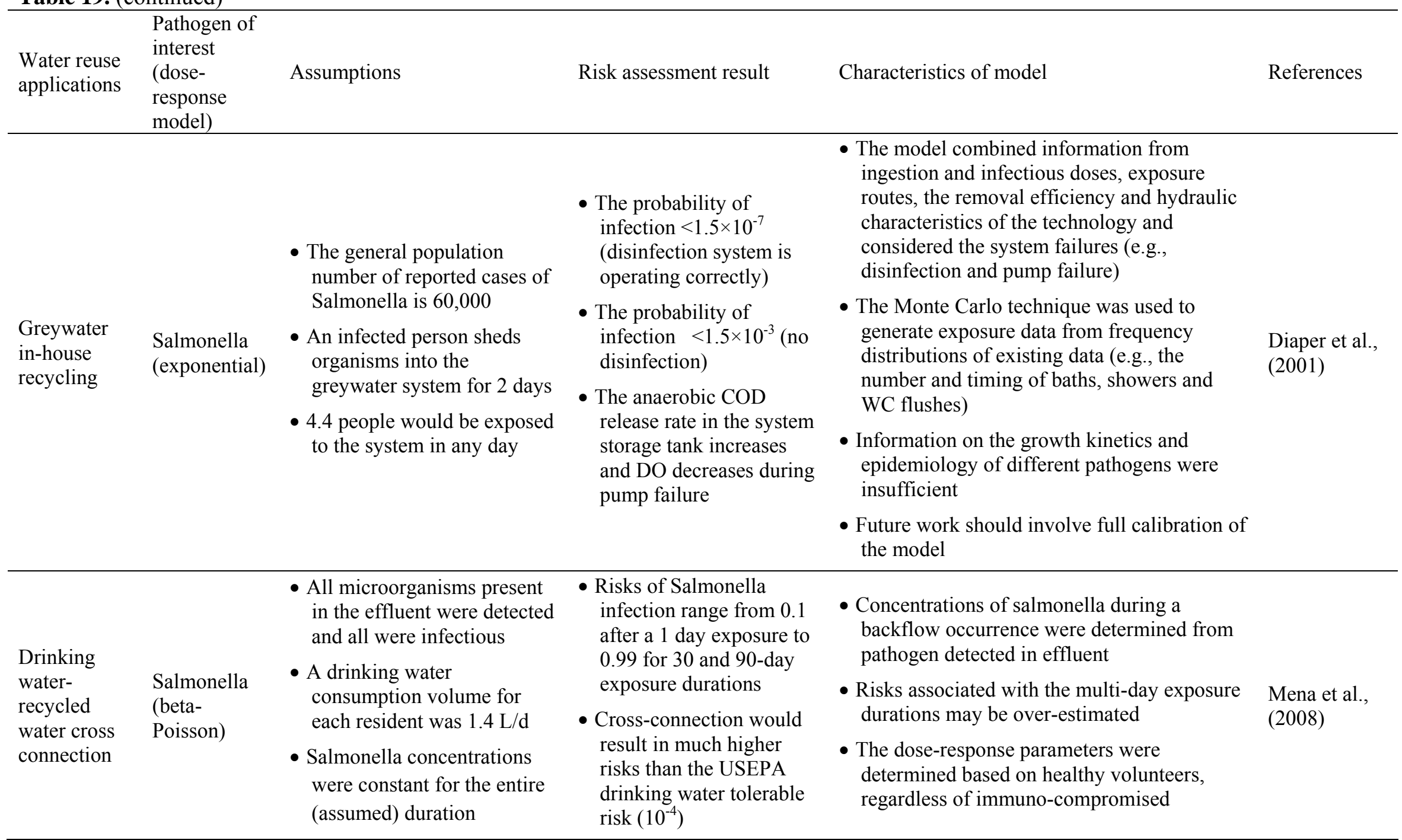


In contrast to static models, dynamic microbial risk assessment models have two main forms: deterministic and stochastic. Table 20 gives characteristics and applications of these two forms. Figure 5 shows the possible disease transmission routines in dynamic MRA models. Label S, E, C, D and P stand for different states associated with pathogen infection. $\mathrm{C} 1$ represents the individuals who are infected but do not have symptoms of disease, whereas C2 represents the individuals who are still infected respectively, but no longer exhibit symptoms of disease. Symbols $\alpha, \beta, \sigma, \delta$ and $\gamma$ are the rates of movement from one epidemiological state to another and $\mathrm{P}_{\text {sym }}$ refers to the probability of a symptomatic response (Soller et al., 2004). Compared with disease transmission routines in static MRA models, dynamic models consider not only the direct exposure to pathogens (S- $\beta 1-E-D)$ but also other indirect factors forming other transmission routines (e.g., S- $\beta 2-\mathrm{E}-\mathrm{D}, \mathrm{C} 1-\mathrm{P}-\mathrm{S}-\mathrm{E}-\mathrm{D}, \mathrm{C} 2-$ P-S-E-D, etc.), such as person-to-person transmission, immunity, asymptomatic infection and incubation period. Hence, the dose-response function is an important health component but not critical since factors specific to the transmission of infectious diseases may also be important. Additionally, as dynamic models also take the immunity into consideration, exposed individuals may not be susceptible to infection or disease because they may already be infected or may be immune from infection due to prior exposure. If the risk is manifest at the population level, the number of individuals susceptible to infection is time varying. Consequently, dynamic models are undoubtedly more sophisticated (Soller, 2006; Soller and Eisenberg, 2008). 
Table 20. Characteristics of deterministic and stochastic models ${ }^{\mathrm{a}}$

\begin{tabular}{|c|c|}
\hline Deterministic model & Stochastic model \\
\hline $\begin{array}{l}\text { The model is expressed as a set of } \\
\text { different equations that have } \\
\text { defined parameters and starting } \\
\text { conditions }\end{array}$ & $\begin{array}{l}\text { The model incorporates probabilities at an } \\
\text { individual level and is evaluated by an iterative } \\
\text { process such as Markov Chain Monte Carlo } \\
\text { analysis }\end{array}$ \\
\hline $\begin{array}{l}\text { - The model does not account for } \\
\text { uncertainty and variability } \\
\text { associated with model parameters }\end{array}$ & $\begin{array}{l}\text { The model requires substantially more data to } \\
\text { account for population dynamics and protection } \\
\text { from infection due to prior exposures }\end{array}$ \\
\hline $\begin{array}{l}\text { - This model is most suitable for } \\
\text { large populations of individuals }\end{array}$ & $\begin{array}{l}\text { - The model accounts for uncertainty and } \\
\text { variability to some extent }\end{array}$ \\
\hline $\begin{array}{l}\text { randomly interacting with one } \\
\text { another }\end{array}$ & $\begin{array}{l}\text { - This model is most suitable for small populations } \\
\text { with heterogeneous mixing patterns }\end{array}$ \\
\hline
\end{tabular}

${ }^{\mathrm{a}}$ Modified from Koopman et al., (2002); Soller et al., (2003).

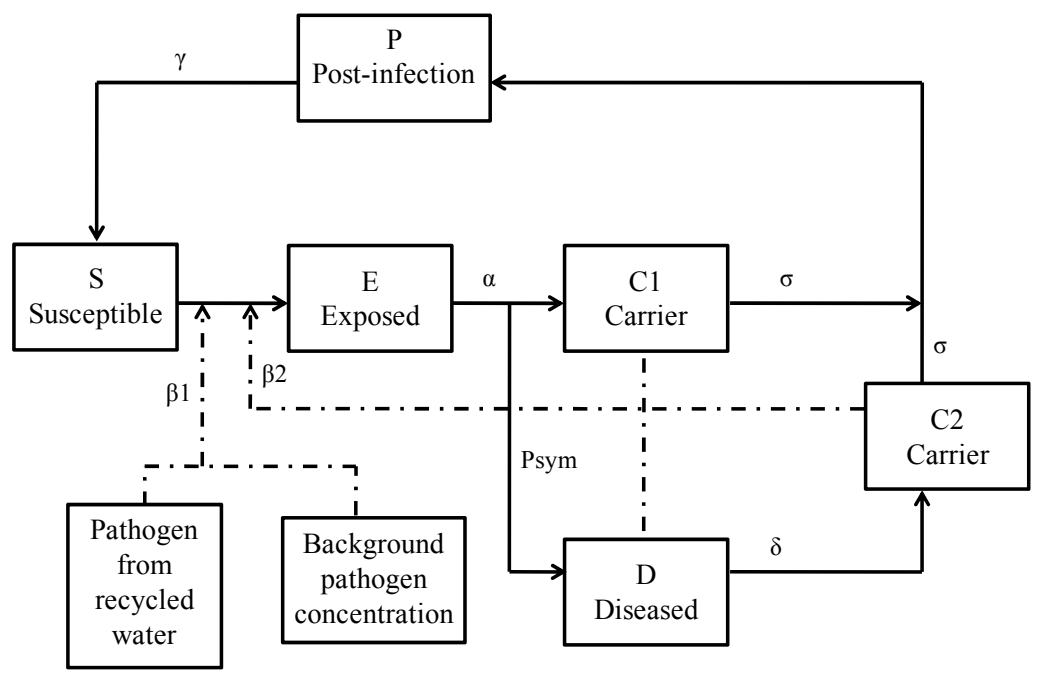

Figure 5. Disease transmission model for a dynamic risk assessment (adapted from Soller et al., 2010b).

There are numerous studies regarding to dynamic MRAs on recycled water reuse applications. Hamilton et al. (2007) have introduced a deterministic recycled water irrigation risk analysis (RIRA) model for Australian irrigation schemes. In RIRA, once pathogen concentration and exposure scenario are inputted together with the chosen dose-response model, the annual risk can be obtained immediately. The result is then compared with U.S. EPA's benchmark $\left(10^{-4}\right)$ to arrive at the optimal decision. Alternatively, when the DALY 
metric is selected, the model output is compared to the WHO's tolerable risk level $\left(10^{-6}\right.$ DALY per year). Overall, the RIRA model is capable of calculating many risk levels in a short period of time with a wide variety of irrigation scenarios, which are convenient and practical for users. The generic and flexible structure of the model also makes it possible to be used in screening level risk assessments for other water reuse scenarios. Besides, the model can investigate the relative merits of different management strategies (e.g., lengthen vs. shorten the time between the last recycled water irrigation event and harvest). Nevertheless, as RIRA is a deterministic model, it fails to account for uncertainty associated with the parameters. With further studies, solutions to convert RIRA into a stochastic model might be available.

On the other hand, stochastic models are increasingly being considered, which incorporate uncertainty, variability and a large number of Monte Carlo trials (e.g., 5000 or 10,000 times). These calculations are mostly relied on commercial softwares such as @risk or Crystal Ball. For example, Hamilton et al. (2006) used a stochastic model for QMRA on five different crops (broccoli, cucumber, Savoy King/Grand Slam cabbage, Winter Head cabbage and lettuce) which were spray irrigated with secondary effluents. Enteric viruses were chosen as the specific microbial hazard to model as they are highly infective. The daily doses of enteric viruses were calculated from the probability distribution functions according to variation factors. It was shown the constant pathogen decay rate $(\mathrm{k}=0.69)$ contributed to a higher risk than the normally distributed decay rate $\left(\mu=1.07, \sigma=0.07 \mathrm{day}^{-1}\right)$. With respect to crops, consuming lettuce resulted in highest risk of infection whereas cucumber had the lowest risk potential. This study also evaluated the impact of different duration times in the environment (e.g., 1 day, 7 days and 14 days) on the annual risk. The mean annual risk was demonstrated to decrease with the increase in duration time. Given a 14-day withholding period, the annual probabilities of enteric virus infection derived from consuming vegetables 
were $10^{-4}$ to $10^{-7}$ which were below the U.S. EPA benchmark $\left(10^{-4}\right)$. Hence, wastewater can only be safely reused for agricultural irrigation with sufficient decay rate and withholding time. Table 21 illustrates other stochastic models used for different water reuse applications. These models were often coupled with other site specific models (e.g., water quality model, hydraulic model and disease transmission model) to represent local reality. However, as stochastic approach is complicated, combining other models often make the analysis even harder to understand and introduce larger uncertainties. The inseparability of variability (natural variation) and uncertainty (lack of knowledge) is also a big weakness. 
Table 21. Stochastic models for risk assessment on recycled water applications

\begin{tabular}{|c|c|c|c|c|c|}
\hline $\begin{array}{l}\text { Water reuse } \\
\text { applications }\end{array}$ & $\begin{array}{l}\text { Pathogen of interest } \\
\text { and models }\end{array}$ & Assumptions & Risk assessment result & Characteristics of model & References \\
\hline $\begin{array}{l}\text { IPR of } \\
\text { stormwater }\end{array}$ & $\begin{array}{l}\text { - Rotavirus and } \\
\text { Campylobacter } \\
\text { (beta-Poisson) } \\
\text { - Cryptosporidium } \\
\text { (exponential) }\end{array}$ & $\begin{array}{l}\text { - The distributions of pathogens } \\
\text { have triangular functions } \\
\text { - Initial concentration, residence } \\
\text { time, aerobic and anaerobic } \\
\text { decay rate were specified for } \\
\text { pathogens }\end{array}$ & $\begin{array}{l}\text { The risks of infection are } \\
1.5 \times 10^{-3}, 4.6 \times 10^{-3} \text { and } 8.4 \times 10^{-3} \\
\text { DALYs for cryptosporidium, } \\
\text { campylobacter and rotavirus } \\
\text { respectively }\end{array}$ & $\begin{array}{l}\text { - The model outcome is a statistical } \\
\text { distribution of risk experienced by the } \\
\text { diverse members of the population } \\
\text { - The QRA model was further developed to } \\
\text { facilitate Monte Carlo simulations which } \\
\text { can provide a sensitivity analysis of the } \\
\text { factors that influence risk }\end{array}$ & $\begin{array}{l}\text { Page et al., } \\
\text { (2008); } \\
\text { Page et al., } \\
(2009)\end{array}$ \\
\hline $\begin{array}{l}\text { Recreational } \\
\text { use (San } \\
\text { Joaquin } \\
\text { River } \\
\text { recharge) }\end{array}$ & $\begin{array}{l}\text { - Viral } \\
\text { gastroenteritis } \\
\text { (beta-Poisson) } \\
\text { - A hydraulic } \\
\text { model } \\
\text { - A disease } \\
\text { transmission } \\
\text { model }\end{array}$ & $\begin{array}{l}\text { - The model virus possessed the } \\
\text { clinical features of rotavirus } \\
\text { - Number of individuals initially } \\
\text { in the susceptible state is equal } \\
\text { to the total population for the } \\
\text { study area } \\
\text { - Data below the detection limit } \\
\text { are present at that limit }\end{array}$ & $\begin{array}{l}\text { - The risk was calculated under } \\
\text { summer } \\
\text { - Secondary treatment is several } \\
\text { orders of magnitude below } \\
\text { the } 8-14 \text { illnesses per } 1000 \\
\text { recreation events (less than } \\
\text { U.S. EPA benchmark } 10^{-4} \text { ) } \\
\text { - Winter tertiary treatment } \\
\text { would further reduce the risk } \\
\text { by } 15-50 \%\end{array}$ & $\begin{array}{l}\text { - The model is composed of } 5 \text { state } \\
\text { variables, } 11 \text { model parameters and } 3 \\
\text { intermediate parameters } \\
\text { - The risk for winter operation represents a } \\
\text { upper bound } \\
\text { - The model is complicated and it is not } \\
\text { practical to estimate the cumulative risk } \\
\text { and carry out separate assessments for all } \\
\text { pathogens } \\
\text { - The distributions of treatment efficiency } \\
\text { underestimate the true treatment } \\
\text { efficiencies } \\
\text { - Storm events and associated urban runoff } \\
\text { were not modelled }\end{array}$ & $\begin{array}{l}\text { Soller et al., } \\
(2003)\end{array}$ \\
\hline $\begin{array}{l}\text { Recreational } \\
\text { use } \\
\text { (Newport } \\
\text { Bay } \\
\text { recharge) }\end{array}$ & $\begin{array}{l}\text { - Rotavirus (beta- } \\
\text { Poisson) } \\
\text { - Water quality } \\
\text { model } \\
\text { - A disease } \\
\text { transmission } \\
\text { model }\end{array}$ & $\begin{array}{l}\text { - The model virus was prevalent } \\
\text { and persistent in the } \\
\text { environment } \\
\text { - The boundary conditions in the } \\
\text { water quality modelling were } \\
\text { based on the maximum } \\
\text { observed concentrations } \\
\text { - Data below the detection limit } \\
\text { are present at that limit }\end{array}$ & $\begin{array}{l}\text { - The risk estimates for } \\
\text { recreation in the Bay were } \\
0.9 \text { illnesses per } 1,000 \\
\text { recreation events which are } \\
\text { less than U.S. EPA } \\
\text { benchmark }\left(10^{-4}\right) \\
\text { - Control measures reduced } \\
\text { pathogen loading by an } \\
\text { additional } 16 \% \text { to } 50 \%\end{array}$ & $\begin{array}{l}\text { - It is not practical to estimate the } \\
\text { cumulative risk } \\
\text { - A number of other more serious disease } \\
\text { outcomes were not modelled } \\
\text { - It is not practical to carry out separate } \\
\text { assessments for all pathogens }\end{array}$ & $\begin{array}{l}\text { Soller et al., } \\
(2006)\end{array}$ \\
\hline
\end{tabular}


Despite strengths and wide applications aforementioned, QMRA models may often be restricted by a paucity of data either from wastewater origins or treated effluents. These models may also be difficult to determine which process components are contributing to disease risk (Donald et al., 2009). Even if the stochastic model is the most advanced and complicated QMRA model, it is inapplicable when uncertain parameters cannot be expressed as probability distributions (Brouwer and Blois, 2008). For these reasons, other risk assessment approaches or integrated tools might be considered. Chen et al. (2010) conducted a hybrid fuzzy-stochastic modelling approach which is a fuzzy set of theory coupled with Monte Carlo analysis to predict the environmental risks associated with recycled water discharges. In this study, a probabilistic risk assessment by Monte Carlo simulations was performed to quantify system uncertainties under several scenarios. Afterwards, triangle fuzzy logic membership functions were constructed to quantify the uncertainties, including imprecise concepts that could not be solved through stochastic theory. This integrated approach is proved to be useful according to a case study on an offshore oil production facility at Grand Banks, Canada. In brief, this model is an extension of single QMRA models and is capable of reflecting the uncertainties associated with the modelling system as well as evaluating various existing standards. Thus, more applications might be reported in the future.

Donald et al. (2009) introduced a Bayesian Network (BN) model for risk assessment of diarrhea connected with the use of recycled water. The conceptual model is illustrated in Figure 6 which depicts the factors and pathways by which recycled water may pose a risk of gastroenteritis. The model was not designed to reflect a particular recycled water system but to indicate the various factors and determine their influence on whether the quality of the water is likely to be classified as acceptable (safe) or unacceptable (unsafe). This conceptual model has been converted to Bayesian models where the various factors and pathways were represented by relevant nodes (Figure 7). The values of each node were expressed as 
probability functions based on an expert opinion. More specifically, marginal probabilities have been adopted for parent nodes (nodes 1, 5, 6, 7, 8, 10, 12), whereas conditional probabilities have been designated for the rest. The model 1 (without considering the uncertainty) was analysed by both Netica and Hugin softwares. Given some prerequisites (the population size was 5000 , the cumulative dose was acceptable and the baseline risk was 0.0151), the model revealed an overall risk of 1.38 for gastroenteritis. As BN softwares in model 1 did not provide uncertainty analysis, the Winbugs software with more complexities was used for model 2 to address the uncertainty. Instead of using Bernoulli distribution $(B(\pi))$, Beta distributions were utilised to represent nodes in model 2, together with the Markov Chain Monte Carlo simulations (12,000 iterations). These modifications were arguably valuable but they also introduced considerable variations to the predictions since the $95 \%$ credible interval was widened due to the change of modelling structure. Besides, the model 2 was inapplicable for a relatively small subset of the population unless favourite conditions were given. Despite the weaknesses, the BN approach on point estimates allows making various predictions to the risks posed under different scenarios. It is also capable of identifying the nodes that contributed most to the outcome of gastroenteritis, thereby providing an additional way of modelling the recycled water quality. 


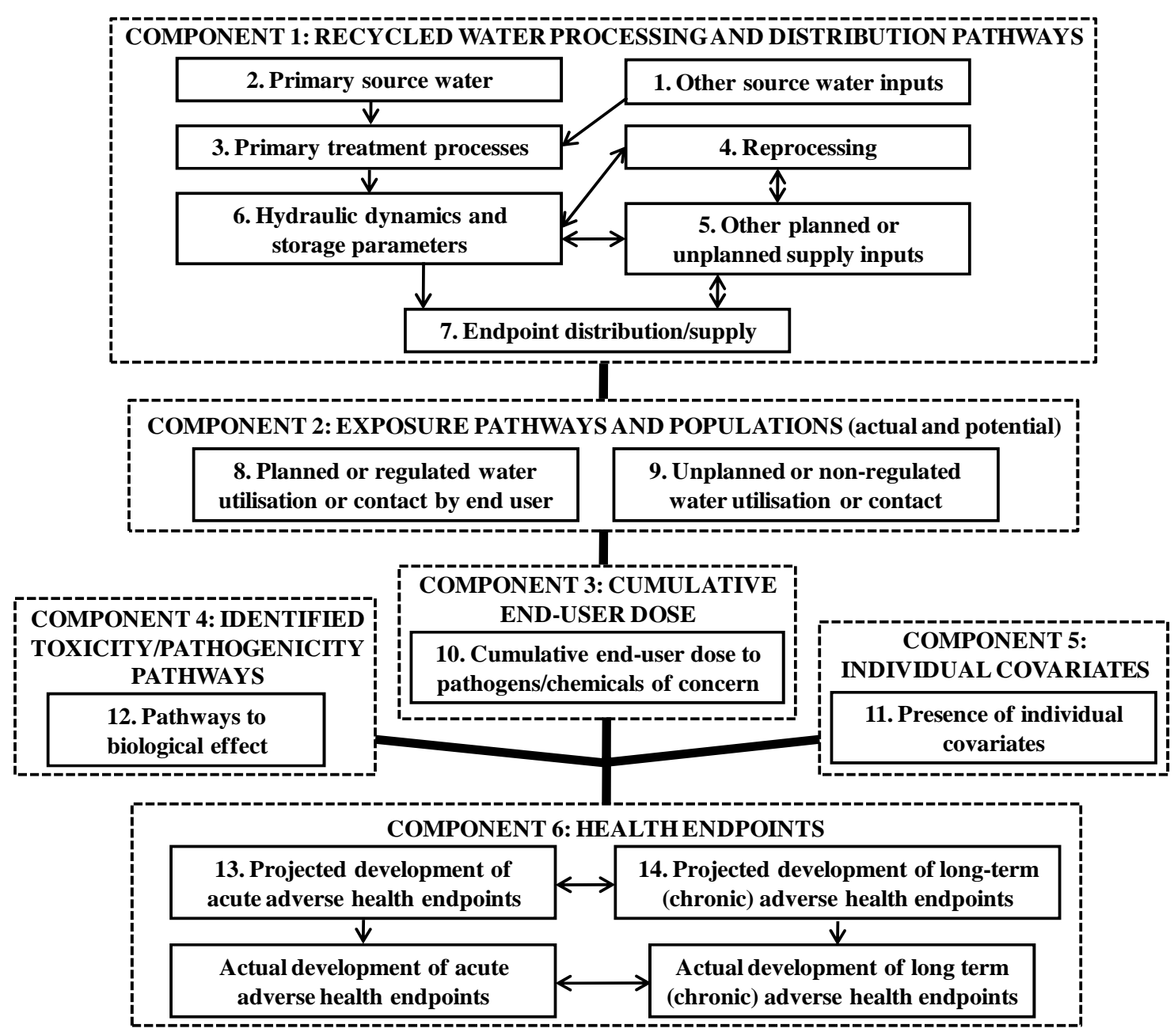

Figure 6. Conceptual model for contaminants that may enter or remain a recycled water scheme (adapted from Donald et al., 2009). 


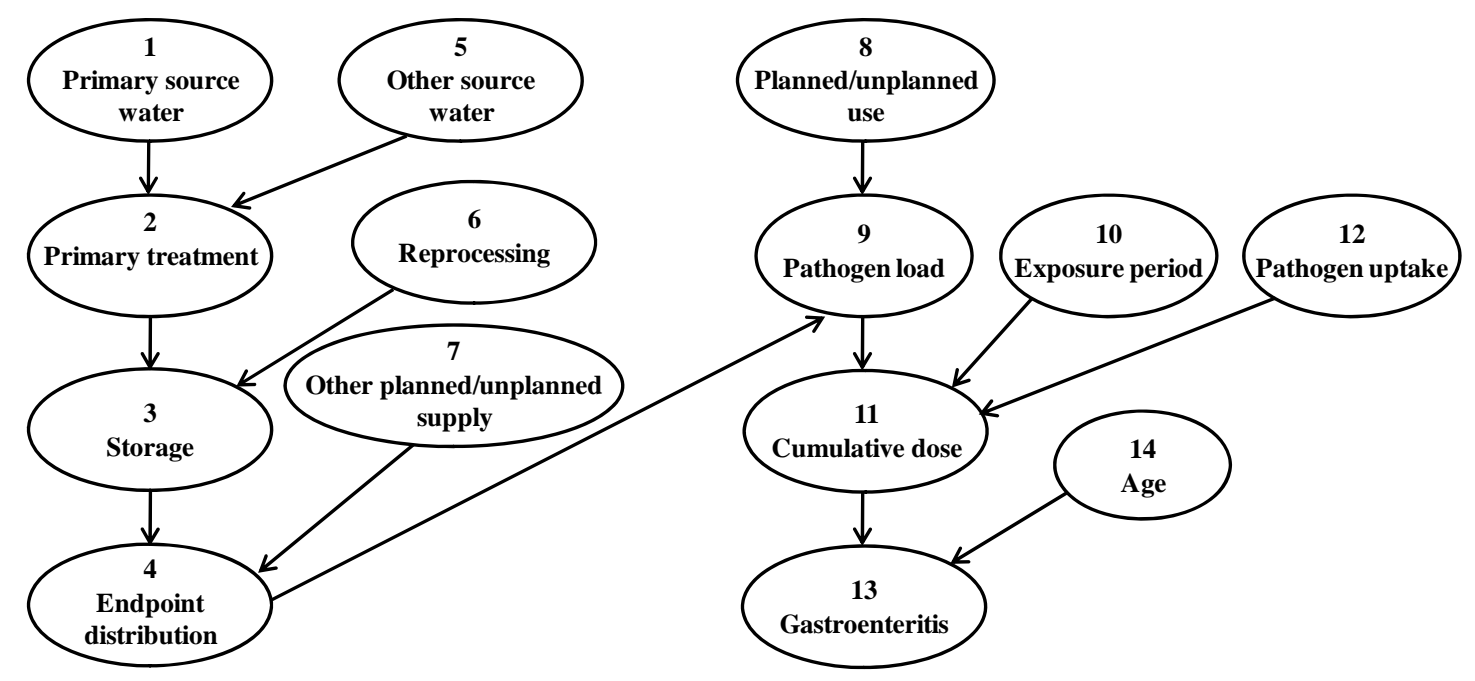

Figure 7. Nodes in Bayesian network based on the conceptual model (adapted from Donald et al., 2009).

Overall, each model aforementioned has its unique strengths and weaknesses. Some models address only one or a few of the numerous components of the physical process regarding water treatment and hazard degradation, while others attempt to take a more comprehensive approach. For exposure to recycled water applications, the selection of an appropriate model form (either static or dynamic) and corresponding analytical approaches are very important which can be identified based on as few as three to four model parameters (Soller et al., 2004). Initial efforts were aimed mainly towards development of deterministic models whereas more recent stochastic models using a probabilistic approach to deal with uncertainties were widely explored and discussed (Rajani and Kleiner, 2001). However, to presume that one model form is most appropriate for all waterborne microbial risk assessment is unrealistic (Soller, 2006). In some cases, it would be better to convert a model into another form. For example, to reflect time varying characteristics, the static models should be translated into dynamic ones. Havelaar et al. (2004) explained the steps to convert deterministic approach to stochastic form. Gronewold and Borsuk (2009) also introduced a software tool for translating deterministic model results into stochastic approaches for water 
quality analysis. The more complicated approach can better reflect realistic conditions, but it does not the most suitable one in any case. When the variations in stochastic results are considerably large, stochastic models should be modified disregarding uncertainty and variability. Despite these efforts, current quantitative risk analyses still have a number of constraints. For example, the dose-response models or curves can often lead to gross overestimates of risk at relatively low doses of reference pathogens. Some accurate models have a maximum risk curve, which limits the upper confidence limit of the dose-response relationship. The lack of quantitative data either on pathogens and/or chemical compounds in recycled water or their relative reduction at each exposure stage probably is the most important constraint (Cook et al., 2008). Additionally, stochastic models as well as other comprehensive analyses tend to be complicated and introduce large variations to modelling outcomes. Therefore, future studies should focus on solving these difficulties, seeking more reliable, viable and integrated approaches.

\section{RISK MANAGEMENT AND COMMUNICATION}

A decrease in recycled water quality due to a series of external and internal risks lead to monetary losses together with the loss of confidence in clients, customers and public authorities. Moreover, Salgot et al. (2003) pointed out that in some cases microcontaminants control is not affordable especially when dealing with small decentralized water reuse schemes. Thus, in addition to use risk control methods (e.g., source control, wastewater quality improvement and exposure control), the implementation of management systems can optimize the processes in the WWTP (e.g., planning, design, operation and customer processes) and distribution systems together with the reduction of the costs. More specifically, the main objectives of the risk management as to water reuse schemes are as follows (Ganoulis and Papalopoulou, 1996): 
1. To protect public health and the environment

2. To help local authorities to choose between alternatives of wastewater reuse applications, decide quickly about the risk and feasibility of a proposal and adapt the solution better to local conditions

3. To minimize risks on public health from particular end uses, identify the potential users from public and private sectors and inform users regarding risk issues

4. Organise regular contacts and exchanges with researchers and publics

To achieve these objects, approaches such as improved policies, changed financial mechanisms and frequent communications should be considered. From the perspective of policies, establishing treatment and discharge standards, taxes and tradable permits can be good incentives for water reuse and effluent quality improvement. In addition, farmers, industrial sectors and households can be motivated in improving water management by lower water prices and subsidies for purchasing new water treatment equipments. Policies should also be combined with monitoring to ensure compliance with incentive programs and safe use of wastewater. Hence, risk managers should keep balancing the cost of increased regulations and monitoring programs against these benefits (Salgot et al., 2006). In respect of economic issues, conducting cost-benefit analysis in risk management is capable of weighing the benefits of different water reuse applications and policies, as well as giving transparency of the processes and structures. As many developing countries have limited ability to invest in or maintain safe water reuse, raising or allocating the needed funds is also good solution, which can be achieved by high-volumetric charges for fresh water consumption and wastewater discharge (Wagner and Strube, 2005; Qadir et al., 2010). Currently, countries including Australia, Singapore, the U.S. and Europe have been adopting integrated management of the water cycle as a water resource solution which requires co-operations 
between risk managers, governmental sectors, environmental agencies and stakeholders in different technical and planning aspects. It will become a global tendency in the future (Angelakis and Durham, 2008).

Furthermore, risk communication is also a key element to substantially reduce the risks (Godfrey et al., 2010). Improvements in communication among government agencies and environmental organizations with expertise in wastewater issues can enhance public policies for wastewater management. Meanwhile, a knowledge, attitudes, beliefs and practices survey should be carried out in communities. Based on analysis data, education campaigns and programs that inform publics about health impacts and mitigation measures can bring down the exposure, reduce health problems and minimize social costs. Besides, multiple stakeholder involvements can further improve the generation and dissemination of information and thereby leading to the success of wastewater reuse projects. (Derry et al., 2006; Qadir et al., 2010).

\section{CONCLUSIONS}

From this paper, the following conclusions can be drawn:

1. To ensure safety, acceptability and reliability of recycled water reuse for public health and the environment, risk controls and assessments on different water reuse categories become essential.

2. Risk control can be achieved through source control, wastewater quality improvement, HACCP control and exposure control. HACCP control has been established at major treatment processes and distribution systems in most developed countries while exposure minimization (e.g., setting exposure barriers, cutting off exposure or transmission routes and improving hygiene conditions) has been conducted widely. 
3. Membrane technologies in wastewater treatment coupled with real-time monitoring programs and soil aquifer treatment processes are proved to be highly efficient both in pathogens and chemical compounds removal. However, for developing countries, unrealistic wastewater treatment processes and extremely stringent reuse guidelines and/or criteria can make implementation difficult or too expensive to be fulfilled. Hence, appropriate treatment and reasonable criteria should be established based on a holistic approach to local, technical, economic, social and cultural contexts.

4. More specifically, when wastewater is subjected to sufficient treatment (e.g., low strength greywater within physical and chemical treatments, medium and high strength greywaters from additional biological treatments, municipal wastewaters under UF/RO or MBR and industrial wastewaters through MBR or CWs), the concentrations of chemicalsand pathogens-of-concern in the effluents can be very low. Even if the community is exposed to large volumes of recycled water within a long period of time, the recycled water still generally proves to be safe to human health and the environment. Comparatively, when wastewater is untreated or insufficiently treated (e.g., less than secondary treatment for agricultural applications and less than tertiary treatment for end uses with potential close human contact) and other risk control approaches are not conducted, water reuse could be a bad idea. In this case, to reduce the detriment effects on health and the surrounding areas, some cost-effective measures (e.g., the establishment of critical control points, exposure minimization, health protection, risk management and education campaigns) should be addressed.

5. Qualitative analysis can only be an initial screening for risk assessment while quantitative approaches can provide detailed numeric risk values for better risk classification by comparison with WHO or U.S. EPA risk benchmarks. 
6. Several models have been introduced in QMRA, including static, deterministic, stochastic, hybrid fuzzy-stochastic and BN models. Dynamic models are more accurate and complicated which account for not only dose-response functions but also secondary transmission related issues. Deterministic models are most suitable ones for large populations while stochastic models are reliable for small populations, especially for estimating the uncertainty and variability. However, only integrated or hybrid modelling systems can partly offset the weaknesses of independent models and will be a viable option in risk analysis in the future.

7. Risk management and communications should be based on results from risk assessment as well as cost and social analyses so that policies can be established towards risk reduction on human health and the environment through a sustainable way.

8. With the accumulation of more toxicological and epidemic data and the help of computerized simulations, the risk assessment will be more accurate and precise. Thus, the guarantee of human health and environment as well as public trust, credibility and confidence on recycled water can be built. Moreover, risk control and assessment will also facilitate the further expansion of current water reuse schemes and the exploration of new end uses in the future.

\section{ACKNOWLEDGEMENT}

This study was supported by Australian Research Council Linkage Project (ARC LP 100100494). 


\section{REFERENCES}

Al-Juaidi, A. E., Kaluarachchi, J. J., and Kim, U. 2010. Multi-criteria decision analysis of treated wastewater use for agriculture in water deficit regions. Journal of the American Water Resources Association, 46(2), 395-411.

Al-Shammiri, M., Al-Saffar, A., Bohamad, S., and Ahmed, M. 2005. Wastewater quality and reuse in irrigation in Kuwait using microfiltration technology in treatment. Desalination, 185(1-3), 213-225.

An, Y. J., Yoon, C. G., Jung, K. W., and Ham, J. H. 2007. Estimating the Microbial Risk of E. coli in Reclaimed Wastewater Irrigation on Paddy Field. Environmental Monitoring and Assessment, 129, 53-60.

Anderson, J. 2003. The environmental benefits of water recycling and reuse. Water Science and Technology, 3(4), 1-10.

Anderson, J., Adin, A., Crook, J., Davis, C., Hultquist, R., Jimenez-Cisneros, B., Kennedy, W., Sheikh, B., and Van der Merwe B. 2001. Climbing the ladder: a step approach to international guidelines for water recycling. Water Science and Technology, 43(10), 1-8.

Angelakis, A. N., and Durham, B. 2008. Water recycling and reuse in EUREAU countries: trends and challenges. Desalination, 218(1-3), 3-12.

Anon, T. 1996. Waterborne pathogens kill 10M-20M people/year. World Water and Environmental Engineering, 31, 574-582.

Arlosoroff, S. 2006. Wastewater management, treatment, and reuse in Israel, in Wastewater Reuse-Risk Assessment. In: Zaidi, K. (Eds.), Decision-Making and Environmental Security. Springer, Dordrecht, Netherlands, pp. 55-64.

Asano, T. 2001. Water from wastewater-the dependable water resource. Water Science and Technology, 45(8), 23-33.

Asano, T., and Cotruvo J. A. 2004. Groundwater recharge with reclaimed municipal wastewater: health and regulatory considerations. Water Research, 38(8), 1941-1951.

Asano, T., Burton, F. L., Leverenz, H. L., Tsuchihashi, R., and Tchobanoglous, G. 2007. Water reuse-issues, technologies and applications. McGraw Hill Book Company, New York.

Ashbolt, N., Schoen, M. E., Soller, J. A., and Roser, D. J. 2010. Predicting pathogen risks to aid beach management: The real value of quantitative microbial risk assessment (QMRA). Water Research, 44(16), 4692-4703.

Australian Academy of Technological Sciences and Engineering (ATSE) 2004. Water Recycling in Australia. Retrieved August 2010 from http://www.atse.org.au/resourcecentre/func-startdown/136/

Barakat, M. A. 2010. New trends in removing heavy metals from industrial wastewater. Arabian Journal of Chemistry, in press.

Benedetti, L., Bixio, D., Claeys, F., and Vanrolleghem, P. A. 2008. Tools to support a modelbased methodology for emission/immission and benefit/cost/risk analysis of wastewater systems that considers uncertainty. Environmental Modelling and Software, 23(8), 10821091.

Bielefeldt, A. R. 2009. Water Treatment, Industrial. In: Schaechter, M. (Eds.), Encyclopedia of Microbiology, Third edition. Elsevier/Academic, Amsterdam, Netherlands, pp. 569586.

Birks, R., Colbourne, J., Hills, S., and Hobson, R. 2004. Microbiological water quality in a large in-building, water recycling facility. Water Science and Technology, 50(2), 165-172.

Blumenthal, U. J., Mara, D. D., Peasey, A., Ruiz-Palacios, G., and Stott, R. 2000. Guidelines for the microbiological quality of treated wastewater used in agriculture: recommendations for revising WHO guidelines. Bulletin of the World Health Organization, 78(9). 
Brisbane Airport Corporation (BAC). 2010. Recycled water management plan risk assessment. Retrieved August 2010 from http://bne.com.au/files/pdf/Working\%20at $\% 20$ brisbane\%20airport/Recycled\%20Water\%20Risk\%20Assessment.pdf

Brouwer, R., and Blois, C. D. 2008. Integrated modelling of risk and uncertainty underlying the cost and effectiveness of water quality measures. Environmental Modelling and Software, 23(7), 922-937.

Calheiros, C. S. C., Rangel, A. O. S. S., and Castro, P. M. L. 2009. Treatment of industrial wastewater with two-stage constructed wetlands planted with Typha latifolia and Phragmites australis. Bioresource Technology, 100(13), 3205-3213.

Campos, C. 2008. New perspectives on microbiological water control for wastewater reuse. Desalination, 218(1-3), 34-42.

Cao, Q. M., Yu, Q. M., and Connell, D. W. 2010. Fate simulation and risk assessment of endocrine disrupting chemicals in a reservoir receiving recycled water. Science of the total environment, 408(24), 6243-6250.

Capra, A., and Scicolone, B. 2007. Recycling of poor quality urban wastewater by drip irrigation systems. Journal of Cleaner Production, 15(16), 1529-1534.

Casani, S., Rouhany, M., and Knochel, S. 2005. A discussion paper on challenges and limitations to water reuse and hygiene in the food industry. Water Research, 39(6), 11341146.

Chapman, S., Leslie, G., and Law, I. 2001. Membrane Bioreactors (MBR) for Municipal Wastewater Treatment-An Australian Perspective, CH2M HILL Australia Pty Ltd. Retrieved November 2010 from http://www.membrane.unsw.edu.au/staff/papers/gleslie/ mbr_for_reuse_awa.pdf

Chen, $\bar{Z}$., Zhao, L., and Lee, K. 2010. Environmental risk assessment of offshore produced water discharges using a hybrid fuzzy-stochastic modelling approach. Environmental Modelling and software, 25(6), 782-792.

Christova-Boal, D., Eden, R. E., and McFarlane, S. 1996. An investigation into greywater reuse for urban residential properties. Desalination, 106(1-3), 391-397.

Cook, A., Devine, B., Rodriguez, C., Roser, D., Khan, S., McGuinness, N., Ashbolt, N., and Weinstein, P. 2008. Assessing the public health impacts of recycled water use. Retrieved May 2011 from http://www.water.wa.gov.au/PWF_UWA_01705_INTERIM_1.pdf?id=23 9

Corre, K. L. 2011. Source control. Retrieved May 2011 from http://www.awmc.uq.edu.au/ index.html?page $=102142$

Deboer, J., and Linstedt, K. D. 1985. Advances in water reuse applications. Water Research, 19(11), 1455-1461.

Dewettinck, T., Van Houtte, E., Geenes, D., Van Hege, K., and Verstraete, W. 2001. HACCP (Hazard Analysis and Critical Control Points) to guarantee safe water reuse and drinking water production-a case study. Water Science and Technology, 43(12), 31-38.

Diaper, C., Dixon, A., Butler, D., Fewkes, A., Parsons, S. A., Strathern, M., Stephenson, T., and Strutt, J. 2001. Small scale water recycling systems-risk assessment and modelling. Water Science and Technology, 43(10), 83-90.

Dixon, A., Butler, D., Fewkes, A., and Robinson, M. 1999. Measurement and modelling of quality changes in stored untreated grey water. Urban Water, 1, 293-306.

Dominguez-Chicas, A., and Scrimshaw, M. D. 2010. Hazard and risk assessment for indirect potable reuse schemes: An approach for reuse in developing Water Safety Plans. Water Research, 44(20), 6115-6123.

Donald, M., Cook, A., and Mengersen, K. 2009. Bayesian network for risk of diarrhea associated with the use of recycled water. Risk Analysis, 29(12), 1672-1685. 
Du-Pisani, P. L. 2006. Direct Reclamation of potable water at Windhoek's Goreangab reclamation plant. Desalination, 188(1-3), 79-88.

Englehardt, J. D. 2004. Predictive Bayesian Dose-Response Assessment for appraising absolute health risk from available information. Human and Ecological Risk Assessment, 10(1), 69-78.

Englehardt, J. D., and Swartout, J. 2004. Predictive population Dose-Response Assessment for cryptosporidium parvum: infection endpoint. Journal of Toxicology and Environmental Health, Part A(67), 651-666.

Environmental Protection and Heritage Council (EPHC). 2009. Australian Guidelines for Water Recycling: Managing Health and Environmental Risks (Phase 2): Stormwater harvesting and reuse. Retrieved May 2011 from http:/www.ephc.gov.au/sites/default/files/ WQ_AGWR_GL_Stormwater_Harvesting_and_Reuse_Final_200907.pdf

Eriksson, E., Auffarth, K., Henze, M., and Ledin, A. 2002. Characteristics of grey wastewater Urban Water, 4(1), 85-104.

Fane, S. A., Ashbolt, N. J., and White, S. B. 2002. Decentralised urban water reuse: The implication of system scale for cost and pathogen risk. Water Science and Technology, 46(6-7), 281-288.

Food and Agriculture Organization (FAO). 1997. Hazard analysis and critical control point (HACCP) system and guidelines for its application, Annex to CAC/RPC 1-1969, Revision 3. Retrieved May 2011 from http://www.fao.org/DOCREP/005/Y1579E/y1579e03.htm

Faustman, E. M. 1996. Review of noncancer risk assessment: application of benchmark dose methods. Human and Ecological Risk Assessment, 3(5), 893-920.

Feo, G. D., Galasso, M., and Belgiorno, V. 2007. Groundwater recharge in an endoreic basin with reclaimed municipal wastewater. Water Science and Technology, 55(1-2), 449-457.

Filipsson, A. F., Sand, S., Nilsson, J., and Victorin, K. 2003. The benchmark dose methodreview of available models, and recommendations for application in health risk assessment. Critical Reviews in Toxicology, 33(5), 505-542.

Friedler, E., Kovalio, R., and Galil, N. I. 2005. On-site greywater treatment and reuse in multi-storey buildings. Water Science and Technology, 51(10), 187-94.

Friedler, E., and Hadari, M. 2006. Economic feasibility of on-site greywater reuse in multistorey buildings. Desalination, 190(1-3), 221-234.

Friedler, E., and Gilboa, Y. 2010. Performance of UV disinfection and the microbial quality of greywater effluent along a reuse system for toilet flushing. Science of the Total Environment, 408(9), 2109-2117.

Fryer, M., Collins, C. D., Ferrier, H., Colvile, R. N., and Nieuwenhuijsen, M. J. 2006. Human exposure modelling for chemical risk assessment: a review of current approaches and research and policy implications. Environmental Science and Policy, 9(3), 261-274.

Galil, N. I., and Levinsky, Y. 2007. Sustainable reclamation and reuse of industrial wastewater including membrane bioreactor technologies: case studies. Desalination, 202(1-3), 411-417.

Ganoulis, J., and Papalopoulou, A. 1996. Risk analysis of wastewater reclamation and reuse. Water Science and Technology, 33(10-11), 297-302.

Gilboa, Y., and Friedler, E. 2008. UV disinfection of RBC-treated light greywater effluent: kinetics, survival and regrowth of selected microorganisms. Water research, 42(4-5), 1043-1050.

Godfrey, S., Singh, S., Labhasetwar, P., Dwivedi, H. B., Parihar, G., and Wate, S. R. 2010. Health-based targets for greywater reuse in residential schools in Madhya Pradesh, India. Water and Environment Journal, 24(3), 215-222.

Greenway, M. 2005. The role of constructed wetlands in secondary effluent treatment and water reuse in subtropical and arid Australia. Ecological Engineering, 25(5), 501-509. 
Gronewold, A. D., and Borsuk, M. E. 2009. A software tool for translating deterministic model results into probabilistic assessments of water quality standard compliance. Environmental Modelling and Software, 24(10), 1257-1262.

Gundry, S., Wright, J., and Conroy, R. 2004. A systematic review of the health outcomes related to household water quality in developing countries. Journal of Water and Health, $2,1-13$.

Government of Western Australia (GWA). 2009. Draft guidelines for the use of recycled water in Western Australia. Retrieved May 2011 from http://www.public.health.wa.gov. au/cproot/2280/2/DRAFT\%20Guidelines $\% 20$ for $\% 20$ the $\% 20$ Use $\% 20$ of $\% 20$ Recycled $\% 20$ Water\%20in\%20Western\%20Australia.pdf

Haas, C. N. 2002. Progress and data gaps in quantitative microbial risk assessment. Water Science and Technology, 46(11-12), 277-284.

Haas, C. N., Rose, J. B., and Gerba, C. P. 1999. Quantitative microbial risk assessment. John Wiley and Sons, New York.

Hamilton, A. J., Stagnitti, F., Premier, R., Boland, A., and Hale, G. 2006. Quantitative microbial risk assessment models for consumption of raw vegetables irrigated with reclaimed water. Applied and Environmental Microbiology, 72(5), 3284-3290.

Hamilton, A. J., Stagnitti, F., Kumarage, S. C., and Premier, R. R. 2007. RIRA: A tool for conducting health risk assessments for irrigation of edible crops with recycled water. Computers and Electronics in Agriculture, 57(1), 80-87.

Hammond, P. B., and Coppick, R. 1990. Valuing health risks, costs and benefits for environmental decision making. National Academy Press, Washington, D.C.

Havelaar, A. H., Nauta, M. J., and Jansen, J. T., 2004. Fine-tuning food safety objectives and risk assessment. International Journal of Food Microbiology, 93(1), 11-29.

Hespanhol, I., and Prost, A. M. E. 1994. WHO guidelines and national standards for reuse and water quality. Water Research, 28(1), 119-124.

Higgins, J., Warnken, J., Sherman, P. P., and Teasdale, P. R. 2002. Survey of users and providers of recycled water: quality concerns and directions for applied research. Water Research, 36(20), 5045-5056.

Holcomb, D. L., Smith, M. A., Ware, G. O., Hung, Y. C., Brackett, R. E., and Doyle, M. P. 1999. Comparison of six dose-response models for use with food-borne pathogens. Risk Analysis, 19(6), 1091-1100.

Huertas, E., Salgot, M., Hollender, J., Weber, S., Dott, W., Khan, S., Schafer, A., Messalem, R., Bis, B., Aharoni, A., and Chikurel, H. 2008. Key objectives for water reuse concepts. Desalination, 218(1-3), 120-131.

International Water Management Institute (IWMI). 2010. Water irrigation and healthAssessing and mitigating risk in low-income countries. Retrieved May 2011 from http://www.idrc.ca/open ebooks/475-8/\#page_3

Jern, N. W. 2006. Industrial Wastewater Treatment. Imperial College Press, London, UK.

Jimenez, B. 2003. Health risk in aquifer recharge with recycled water. In: Aertgeerts, R., Angelakis, A. (Eds.), State of the Art Report Health Risks in Aquifer Recharge Using Reclaimed Water. World Health Organization, Geneva, Switzerland, pp.16-109.

Jimenez, B., and Chavez, A. 2004. Quality assessment of an aquifer recharged with wastewater for its potential use as drinking water source: El-Mezquital Valley case. Water Science and Technology, 50(2), 269-276.

Jimenez, B., and Asano, T. 2008. Water reuse: an international survey of current practice, issues and needs. IWA publishing, London.

Jolis, D., Pitt, P., and Hirano, R. 1999. Risk assessment for Cryptosporidium parvum in recycled water. Water Research, 33(13), 3051-3055. 
Juhna, T., Klavins, M., and Eglite, L. 2003. Sorption of humic substances on aquifer material at artificial recharge of groundwater. Chemosphere, 51(9), 861-868.

Kamizoulis, G. 2008. Setting health based targets for water reuse (in agriculture). Desalination, 218(1-3), 154-163.

Kelly, J., and Stevens, D. 2005. Recycled water tour 05, recycled water in Australia. Retrieved May 2011 from http:/www.recycledwater.com.au/uploads/File/documents/ Final\%20Report\%20Tour05LR.pdf

Khan, S. J. 2010. Quantitative chemical exposure assessment for water recycling schemes. Australian Government National Water Commission. Retrieved January 2011 from http://www.nwc.gov.au/www/html/2737-quantative-chemical-exposure-assessment-forwater-recycling-schemes---no-27.asp

Khan, S. J., and Roser, D. 2007. Risk assessment and health effects studies of indirect potable reuse schemes, CWWT Report 2007/08. Retrieved January 2011 from http://www.qwc.qld.gov.au/prw/pdf/prw-studies-indirect-potable-reuse.pdf

Koopman, J. S., Chick, S. E., Simon, C. P., Riolo C. S., and Jacquez, G. 2002. Stochastic effects on endemic infection levels of disseminating versus local contacts. Mathematical Biosciences, 180(1-2), 49-71.

Lazarova, V., and Bahri, A. 2005. Water reuse for irrigation: agriculture, landscapes and turf grass. CRC, Florida.

Li, F. Y. 2009. Review of the technological approaches for grey water treatment and reuses. Science of the Total Environment, 407(11), 3439-3449.

Libralato, G., Annamaria, V. G., and Francesco, A. 2010. How toxic is toxic? A proposal for wastewater toxicity hazard assessment. Ecotoxicology and Environmental Safety, 73(7), $1602-1611$.

Liran, A., Juanico, M., and Shelef, G. 1994. Coliform removal in a stabilization reservoir for wastewater irrigation in Israel. Water Research, 28(6), 1305-1314.

Logsdon, G. S. 2006. How waterborne disease outbreaks relate to treatment failures. Association of Environmental Engineering \& Science Professors case studies compilation. Retrieved January 2011 from http://www.aeespfoundation.org/publications/pdf/ AEESP_ CS_3.pdf

Lyko, S., Wintgens, T., and Melin, T. 2005. Estrogenic trace contaminants in wastewaterpossibilities of membrane bioreactor technology. Desalination, 178(1-3), 95-105.

Maeng, S. K., Ameda, E., Sharma, S. K., Grutzmacher, G., and Amy, G. L. 2010. Organic micropollutant removal from wastewater effluent-impacted drinking water sources during bank filtration and artificial recharge. Water Research, 44(14), 4003-4014.

Mara, D. 2003. Domestic wastewater treatment in developing countries. Earthscan, London, UK.

March, J. G., Gual, M., and Orozco, F. 2004. Experiences on greywater reuse for toilet flushing in a hotel (Mallorca Island, Spain). Desalination, 164(3), 241-247.

McBride, G., Till, D., Ryan, T., Ball, A., Lewis, G., Palmer, S. and Weinstein, P. 2002. Pathogen Occurrence and Human Health Risk Assessment Analysis, Freshwater Microbiology Research Programme Report. Retrieved January 2011 from http://www.mfe.govt.nz/publications/water/freshwater-microbiology-nov02/

Melin, T., Jefferson, B., Bixio, D., Thoeye, C., Wilde, W. D., Koning, J. D., Van der Graaf, J., and Wintgens, T. 2006. Membrane bioreactor technology for wastewater treatment and reuse. Desalination, 187(1-3), 271-282.

Mena, K., Mota, L. C., Meckes, M. C., Green, C. F., Hurd, W. W., and Gibbs, S. G. 2008. Quantitative microbial risk assessment of a drinking water-wastewater cross-connection simulation. Journal of Environmental Engineering and Science, 7(5), 525-530. 
Meric, S., and Fatta, D. 2007. Wastewater reuse, risk assessment, decision making-A threeended narrative subject. In: Zaidi, K. (Eds.), Wastewater Reuse-Risk Assessment, Decision-Making and Environmental Security. Springer, Dordrecht, Netherlands, pp.193204.

Minhas, P. S., and Samra, J. S. 2004. Wastewater use in peri-urban agriculture: impacts and opportunities. Central Soil Salinity Research Institute, Karnal, India.

Mohsen, M. S., and Jaber, J. O. 2002. Potential of industrial wastewater reuse. Desalination, 152(1-3), 281-289.

NRMMC-EPHC-AHMC. 2006. Overview of the Australian Guidelines for Water Recycling: Managing Health and Environmental Risks 2006. Retrieved January 2011 from http://www.ephc.gov.au/sites/default/files/WQ_AGWR_Sum_Managing_Health_Enviro nmental_Risks_Phase1_Overview_200806.pdf

New South Wales Food Authority (NSWFA). 2008. Water reuse guideline: for food businesses in NSW considering reusing water. Retrieved January 2011 from http://www.foodauthority.nsw.gov.au/_Documents/industry_pdf/water-reuseguidelines.pdf

Olivieri, A. W., Eisenberg, D. M., Cooper, R. C., Tchobanoglousand, G., and Gagliardo, P. 1996. Recycled water-A source of potable water: city of San Diego health effects study. Water Science and Technology, 33(10-11), 285-296.

Oron, G., Gillerman, L., Bick, A., Gargir, M., Manor, Y., Buriakovsky, N., and Hagin, J. 2007. Advanced low quality waters treatment for unrestricted use purposes: imminent challenges. Desalination, 213(1-3), 189-198.

Oron, G., Gillerman, L., Buriakovsky, N., Bick, A., Gargir, M., Dolan, Y., Manor, Y., Katz, L., and Hagin, J. 2008. Membrane technology for advanced wastewater reclamation for sustainable agriculture production. Desalination, 218(1-3), 170-180.

O’Toole, J., Leder, K., Sinclair, M., 2007. Recycled water and human health effects. Australian Family Physician 36 (12), 998-1000.

O'Toole, J., Sinclair, M., and Leder, K. 2008. Recycled water exposure: filling the data gaps. Water, 35(8), 52-57.

Page, D., Barry, K., Pavelic, P., Dillon, P., and Chassagne, A. 2008. Preliminary quantitative risk assessment for the Salisbury stormwater ASTR Project, Water for a Healthy Country Flagship Report August 2008. Retrieved January 2011 from http://www.clw.csiro.au/ publications/waterforahealthycountry/2008/wfhc-Salisbury-ASTR-HACCP.pdf

Page, D., Vanderzalm, J., Barry, K., Levett, K., Kremer, S., Ayuso-Gabella, M.N., Dillon, P., Toze, S., Sidhu, J., Shackleton, M., Purdie, M., and Regel, R. 2009. Operational residual risk assessment for the Salisbury stormwater ASTR Project. Retrieved January 2011 from http://www.hannover.csiro.au/files/files/psgp.pdf

Park, C., Hong, S. W., Chung, T. H., and Choi, Y. S. 2010. Performance evaluation of pretreatment processes in integrated membrane system for wastewater reuse. Desalination, 250(2), 673-676.

Pearce, G. K. 2008. UF/MF pre-treatment to RO in seawater and wastewater reuse applications: a comparison of energy costs. Desalination, 222(1-3), 66-73.

Peasey, A., Blumenthal, U., Mara, D., and Ruiz-Palacios, G. 2000. A review of policy and standards for wastewater reuse in agriculture: a Latin American perspective. Retrieved January 2011 from http://www.bvsde.paho.org/bvsacd/cd29/reuse.pdf

Persoone, G., Marsalek, B., Blinova, I., Torokne, A., Zarina, D., Manusadzianas, L., NaleczJawecki, G., Tofan, L., Stepanova, N., Tothova, L., and Kolar, B. 2003. A practical and user-friendly toxicity classification system with microbiotests for natural waters and wastewaters. Environmental Toxicology, 18(6), 395-402. 
Pidou, M., Avery, L., Stephenson, T., Jeffery, P., Parsons, S. A., Liu, S. M., Memon, F. A., and Jefferson, B. 2008. Chemical solutions for greywater recycling. Chemosphere, 71(1), $147-155$.

Qadir, M., Wichelns, D., Raschid-Sally, L., McCornick, P. G., Drechsel, P., Bahri, A., and Minhas, P. S. 2010. The challenges of wastewater irrigation in developing countries. Agricultural Water Management, 97(4), 561-568.

Qiang, H., Li, H., and Jun, Z. 2008. Application of sustainable water system-the demonstration in Chengdu (China). In: Proceedings of third SWITCH Scientific Meeting, Belo Horizonte, Brazil.

Rajani, B., and Kleiner, Y. 2001. Comprehensive review of structural deterioration of water mains: physically based models. Urban Water, 3(3), 151-164.

Ritter, L., Totman, C., Krishnan, K., Carrier, R., Vezina, A., and Morisset, V. 2007. Deriving uncertainty factors for threshold chemical contaminants in drinking water. Journal of Toxicology and Environmental Health, Part B, 10(7), 527-557.

Rodriguez, C., Cook, A., Buynder, P. V., Devine, B., and Weinstein, P. 2007. Screening health risk assessment of micropullutants for indirect potable reuse schemes: a three-tiered approach. Water Science and Technology, 56(11), 35-42.

Rodriguez, C., Buynder, P.V., Lugg, R., Blair, P., Devine, B., Cook, A. and Weinstein, P. 2009. Indirect potable reuse: a sustainable water supply alternative. International Journal of Environmental Research and Public Health, 6, 1174-1209.

Rose, J. B. 2007. Water reclamation, reuse and public health. Water Science and Technology, 55(1-2), 275-282.

Rose, J. B., Sun, G., Gerba, C. P., and Sinclair, N. A. 1991. Microbial quality and persistence of enteric pathogens in graywater from various household sources. Water Research, 25(1), $37-42$.

Roser, D., Khan, S., Davies, C., Signor, R., Petterson, S., and Ashbolt, N. 2006. Screening health risk assessment for the use of microfiltration-reverse osmosis treated tertiary effluent for replacement of environmental flows, CWWT Report 2006-20. Retrieved January 2011 from http://www.planning.nsw.gov.au/asp/pdf/06_0190_appendixd1.pdf

Salgot, M., Verges, C., and Angelakis, A. N. 2003. Risk assessment in wastewater recycling and reuse. Water Science and Technology, 3(4), 301-309.

Salgot, M., Huertas, E., Weber, S., Dott, W., and Hollender, J. 2006. Wastewater reuse and risk: definition of key objectives. Desalination, 187(1-3), 29-40.

Santala, E., Uotila, J., Zaitsev, G., Alasiurua, R., Tikka, R., and Tengvall, J. 1998. Microbiological grey water treatment and recycling in an apartment building. In: Proceedings of 2nd International Advanced Wastewater Treatment, Recycling and Reuse, September 14-16, Milan, Italy.

Shatanawi, M., Hamdy, A., and Smadi, H. 2007. Urban wastewater: problems, risks and its potential use for irrigation. Retrieved January 2011 from http://ressources.ciheam.org/om/ pdf/a66/00800229.pdf

Shuval, H., Lampert, Y., and Fattal, B. 1997. Development of a risk assessment approach for evaluating wastewater recycling and reuse standards for agriculture. Water Science and Technology, 35(11-12), 15-20.

Sipma, J., Osuna, B., Collado, N., Monclus, H., Ferrero, G., Comas, J., and Rodriguez-Roda, I. 2010. Comparison of removal of pharmaceuticals in MBR and activated sludge systems. Desalination, 250(2), 653-659.

Soller, J. A. 2006. Use of microbial risk assessment to inform the national estimate of acute gastrointestinal illness attributable to microbes in drinking water. Journal of Water and Health, 4, 165-186. 
Soller, J. A., and Eisenberg, J. N. S. 2008. An evaluation of parsimony for microbial risk assessment models. Environmetrics, 19(1), 61-78.

Soller, J. A., Olivieri, A. W., Crook, J., Cooper, R. C., Tchobanoglous, G., Parkin, R., Spear, R., and Eisenberg, J. N. S. 2003. Risk-based approach to evaluate the public health benefit of additional wastewater treatment. Environmental Science and Technology, 37(9), 18821891.

Soller, J. A., Olivieri, A. W., Eisenberg, J. N. S., Sakaji, R., and Danielson, R. 2004. Evaluation of microbial risk assessment techniques and applications. IWA publishing, Alexandria.

Soller, J. A., Eisenberg, J. N. S., DeGeorge, J. F., Cooper, R. C., Tchobanoglous, G., and Olivieri, A. W. 2006. A public health evaluation of recreational water impairment. Journal of Water and Health, 4(1), 1-19.

Soller, J. A., Bartrand, T., Ashbolt, N. J., Ravenscroft, J., and Wade, T. J. 2010a. Estimating the primary etiologic agents in recreational freshwater impacted by human sources of faecal contamination. Water Research, 44(16), 4736-4747.

Soller, J. A., Embrey, M., Tuhela, L., Ichida, A., and Rosen, J. 2010b. Risk-based evaluation of Escherichia coli monitoring data from undisinfected drinking water. Journal of Environmental Management, 91(11), 2329-2335.

Sostar-Turk, S., Petrinic, I., and Simonic, M. 2005. Laundry wastewater treatment using coagulation and membrane filtration. Resource, Conservation and Recycling, 44(2), 185196.

Stein, P. L. 2000. The great Sydney water crisis of 1998. Water, Air and Soil Pollution, 123(1-4), 419-436.

Stevens, D. P., Smolenaars, S., and Kelly, J. 2008. Irrigation of amenity horticulture with recycled water, A handbook for parks, gardens, lawns, landscapes, playing fields, golf courses and other public open spaces. Retrieved January 2011 from http://www.irrigation. org.au/assets/pages/6E9E6203-170851EBA65470E3F41123EB/Amenity\%20Hort\%20Arr is $\% 20$ Recycled\%20Wat er\%20FINAL.pdf

Storey, M. V., and Kaucner, C. E. 2009. Understanding the growth of opportunistic pathogens within distribution systems, Research Report 79. Retrieved January 2011 from http://www.wqra.com.au/publications/document-search/?download=110

Tanaka, H., Asano, T., Schroeder, E. D., and Tchobanoglous, G. 1998. Estimating the safety of wastewater reclamation and reuse using enteric virus monitoring data. Water Environment Research, 70(1), 39-51.

Tonkes, M., de Graaf, P. J. F., and Graansma, J. 1999. Assessment of complex industrial effluents in the Netherlands using a whole effluent toxicity (or WET) approach. Water Science and Technology, 39(10-11), 55-61.

Toze, S. 1997. Microbial pathogens in wastewater, literature review for urban water, systems multi-divisional research program, technical report No. 1/97. Retrieved May 2011 from http://www.clw.csiro.au/ publications/technical97/tr1-97.pdf

Toze, S. 2006a. Water reuse and health risks-real vs. perceived. Desalination, 187(1-3), 4151.

Toze, S. 2006b. Reuse of effluent water-benefits and risks. Agricultural Water management, 80(1-3), 147-159.

Toze, S., Bekele, E., Page, D., Sidhu, J., and Shackleton, M. 2010. Use of static Quantitative Microbial Risk Assessment to determine pathogen risks in an unconfined carbonate aquifer used for Managed Aquifer Recharge. Water Research, 44(4), 1038-1049.

Trang, D. T., Van der Hoek, W., Cam, P. D., Vinh, K. T., Hoa, N. V., and Dalsgaard, A. 2006. Low risk for helminth infection in wastewater-fed rice cultivation in Vietnam. Journal of Water and Health, 4, 321-331. 
United Nations (UN). 2003. Wastewater treatment technologies: A general review. Economic and Social Commission for Western Asia. Retrieved January 2011 from http://www.escwa.un.org/information/publications/edit/upload/sdpd-03-6.pdf

U.S. Environmental Protection Agency (EPA). 2004. Guidelines for Water Reuse. Retrieved January 2011 from http://www.epa.gov/ord/NRMRL/pubs/625r04108/625r04108.pdf

Van Breemen, L. W. C. A., Ketelaars, H. A. M., Hoogenboezen, W., and Medema, G. 1998. Storage reservoirs-a first barrier for pathogenic microorganisms in the Netherlands. Water Science and Technology, 37(2), 253-60.

Van Houtte, E., and Verbauwhede, J. 2008. Operational experience with indirect potable reuse at the Flemish Coast. Desalination, 218(1-3), 198-207.

Van Leeuwen, J. 1996. Reclaimed water- an untapped resource. Desalination, 106(1-3), 233-240.

Vindimian, E., Garric, J., Flammarion, P., Thybaud, E., and Babut, M. 1999. An index of effluent aquatic toxicity designed by partial least squares regression, using acute and chronic tests and expert judgements. Environmental Toxicology and Chemistry, 18(10), 2386-2391.

Vymazal, J. 2009. The use constructed wetlands with horizontal sub-surface flow for various types of wastewater. Ecological Engineering, 35(1), 1-17.

Vymazal, J. 2002. The use of sub-surface constructed wetlands for wastewater treatment in the Czech Republic: 10 years experience. Ecological Engineering, 18(5), 633-646.

Wagner, M., and Strube, I. 2003. Risk management in waste water treatment. Water Science and Technology, 52(12), 53-61.

Wang, L. K., Hung, Y. T., Lo, H. H., and Yapijakis, C. 2004. Handbook of industrial and hazardous waste treatment, Second Edition. Marcel Dekker, New York.

Water Corporation. 2008. Greywater reuse and recycling, Water Forever Information Sheet. Retrieved January 2011 from http://www.thinking50.com.au/download.cfm?Download File=7985994B-1708-51EB-A65FCE8F3F58835DGreywaterReuse and Recycling

Weber, S., Khan, S., and Hollender, J. 2006. Human risk assessment of organic contaminants in reclaimed wastewater used for irrigation. Desalination, 187(1-3), 53-64.

Wedick, M. 2007. Toward sustainable water systems: Potable reuse of wastewater, UP502Environmental Planning. Retrieved January 2011 from http://www.melonwedick.com/ Water.pdf

Westrell, T., Schonning, C., Stenstro, T. A., and Ashbolt, N. J. 2004. QMRA (quantitative microbial risk assessment) and HACCP (hazard analysis and critical control points) for management of pathogens in wastewater and sewage sludge treatment and reuse. Water Science and Technology, 50(2), 23-30.

World Health Organization (WHO). 2003. Guidelines for drinking water quality, Third edition. Retrieved January 2011 from http://www.who.int/water_sanitation_health/dwq/ gdwq3rev/en/

World Health Organization (WHO). 2006. Guidelines for the safe use of wastewater, excreta and greywater, Volume 2, Wastewater use in agriculture. Retrieved January 2011 from http://whqlibdoc.who.int/publications/2006/9241546832_eng.pdf

Winward, G. P., Avery, L. M., Frazer-Williams, R., Pidou, M., Jeffrey, P., Stephenson, T., and Jefferson, B. 2008. A study of the microbial quality of greywater and an evaluation of treatment technologies for reuse. Ecological Engineering, 32(2), 187-197.

Yim, S. K., Ahn, W. Y., Kim, G. T., Koh, G. W., Cho, J., and Kim, S. H. 2007. Pilot-scale evaluation of an integrated membrane system for domestic water reuse on islands. Desalination, 208(1-3), 113-124. 
Zha, J. M., and Wang, Z. J. 2005. Assessing technological feasibility for wastewater reclamation based on early life stage toxicity of Japanese medaka. Agricultural, Ecosystems and Environment, 107(2-3), 187-198. 